Historic, archived document

Do not assume content reflects current scientific knowledge, policies, or practices. 



\section{copon \\ Louisiana \\ FOREST RESOURCES \\ and INDUSTRIES}

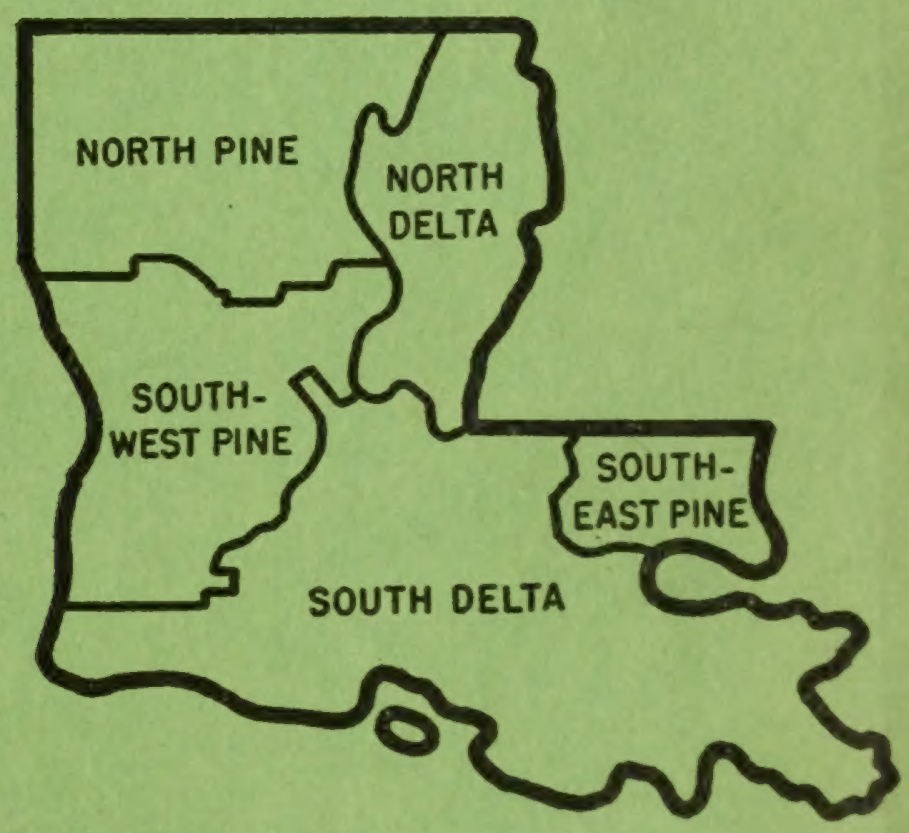

FOREST SERVICE

United States Department of Agriculture

Miscellaneous Publication No. 519 

UNITED STATES DEPARTMENT OF AGRICULTURE MISCELLANEOUS PUBLICATION NO. 5 I 9 WASHINGTON, D. C., AUGUST I 943

\title{
Louisiana Forest Resources and Industries
} \\ by R. K. WINTERS, forester \\ G. B. WARD, Jr., junior forester \\ and I. F. ELDREDGE, chief, field division, Forest Survey \\ SOUTHERN FOREST EXPERIMENT STATION \\ FOREST SERVICE \\ $\rightarrow \gg \cdot \ll$ \\ Mensurational Analyses in charge of \\ P. R. WHEELER, forest economist
}

UNITED STATES GOVERNMENT PRINTING OFFICE • WASHINGTON • 1943 


\section{The Forest Survey}

EPENDABLE information on the supply of all raw materials is vital to the conduct of the war and to the success of present efforts at post-war planning. This economic survey of an integral part of the Nation's reservoir of raw material - our forests - and of the industries dependent upon them is essential to a complete understanding of resource potentialities. The data presented result from the first Nation-wide field inventory ever to be made of the volume, quality, and species of the timber resource, undertaken primarily as an essential contribution to the national, social, and economic welfare in peacetime. The rapidly changing conditions of our economic and social life since the second World War began have accentuated the need for publishing the facts already gathered and the conclusions to be drawn from them.

The Nation-wide Forest Survey, authorized by the McSweeney-McNary Forest Research Act of May 22, 1928, is obtaining facts basic to a system of planned forest-land management and use for each of the States and forest regions, and for the Nation; and through analysis of these data is aiding in the formulation of guiding principles and policies fundamental to permanent forest land use.

The fivefold purpose of the Forest Survey is: (1) To make a field inventory of the present supply of timber and other forest products; (2) to ascertain the rate at which this supply is being increased through growth; (3) to determine the rate at which it is being diminished through industrial and domestic uses, windfall, fire, disease, and other causes; (4) to determine the present consumption and the probable future trend in requirements for timber and other forest products; and (5) to interpret and correlate these findings with existing and anticipated economic conditions, as an aid in the formulation of both private and public policies for the effective and rational use of land suitable for forest production.

The plan has been to publish the results of this investigation as they become available. Necessarily, the data here presented apply to large areas and should not be interpreted as portraying correctly the forest situation for small sections, the conditions of which may be either better or poorer than the average for the entire unit or State. They supply the general background for the intensive study of critical situations. As might be expected, the recommendations included in these reports are adapted to the long-time character of timber growing and presuppose normal peacetime conditions. Any that are out of line with war requirements are obviously in abeyance for the present.

The survey is conducted in the various forest regions by the forest experiment stations of the Forest Service; in the South by the Southern Forest Experiment Station with headquarters in New Orleans, La.

Raymond D. Garver, Director, Forest Survey. 

L $\mathrm{O}$
I
S I A
N
A
F $\mathrm{O}$
R E S T
R
E S

o
U
R C E

\section{Contents}

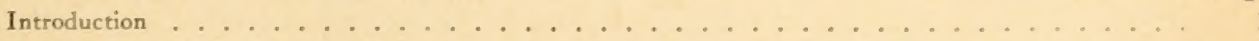

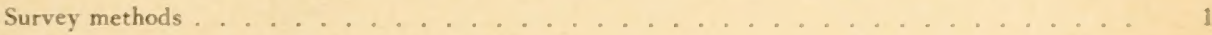

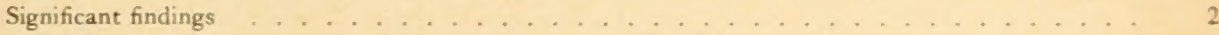

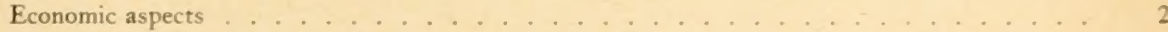

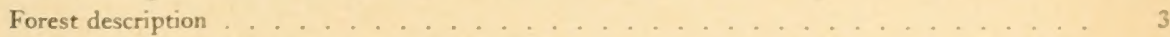

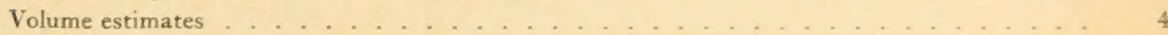

Special forest resources ................................... 4

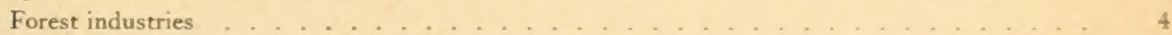

Forest increment and drain ....................................... 4

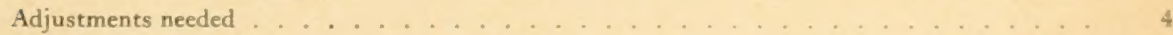

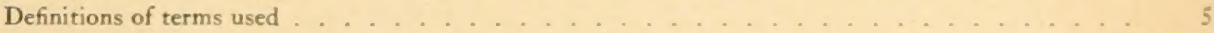

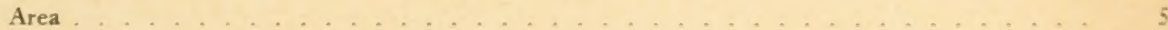

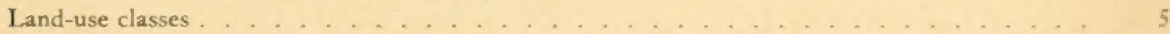

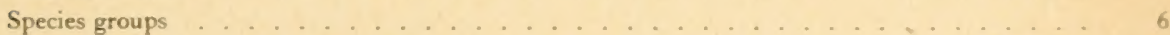

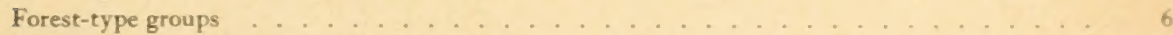

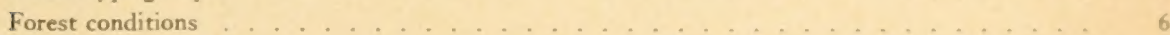

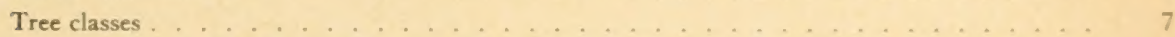

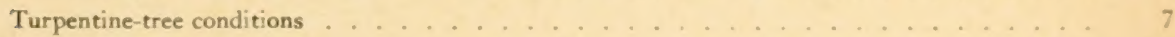

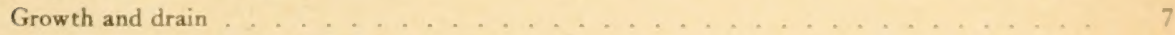

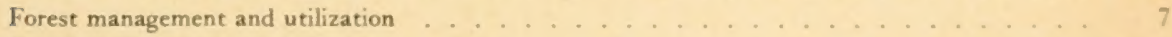

Units of measure . . . . . . . . . . . . . . . . . . . . . 7

Forest description . . . . . . . . . . . . . . . . . . . . . . . . . . . . . . . . .

Bottom-land hardwood forests . . . . . . . . . . . . . . . . . . 9

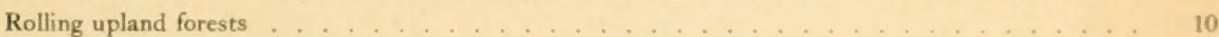

Economics of the forest situation . . . . . . . . . . . . . . . . . . .

Land use . . . . . . . . . . . . . . . . . . . . 14

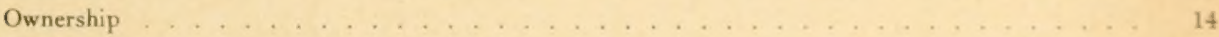

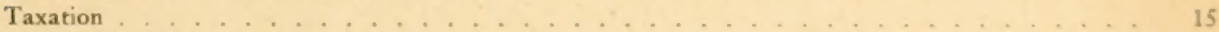

Forest inventory . . . . . . . . . . . . . . . . . . . . . . . . . . .

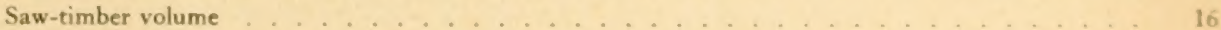

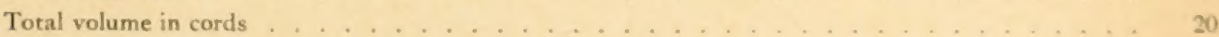

Cubic-foot volume . . . . . . . . . . . . . . . . . . . . . . . . . . . . . . . 21

Special forest resources . . . . . . . . . . . . . . . . . . . . . . . . . . . . . . . . . . . 21

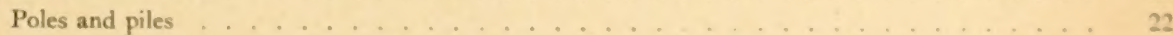

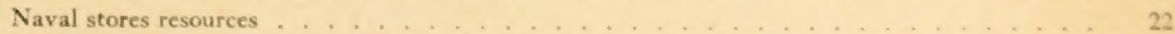

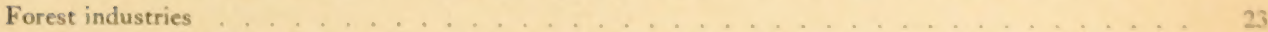

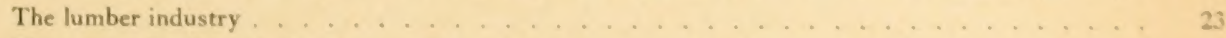

The nonlumber forest industries . . . . . . . . . . . . . . . . . . . . . . . 21

Miscellaneous wood products . . . . . . . . . . . . . . . . . . . . 25

Pulp mills . . . . . . . . . . . . . . . . . . . . . . . . . . . . . . . . . . . . . . . . . . . . 25

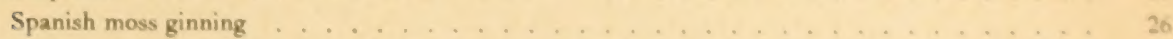

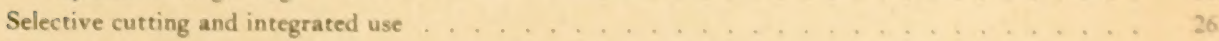

Employment ................................. 29 


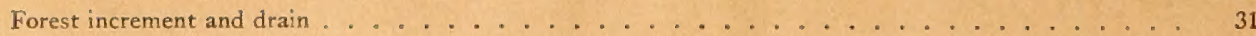

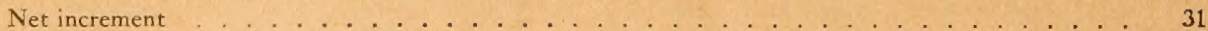

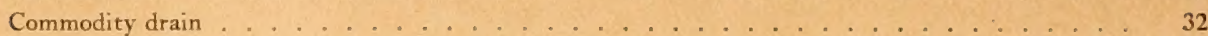

Comparison of net increment and commodity drain . . . . . . . . . . . . . . . . . . 33

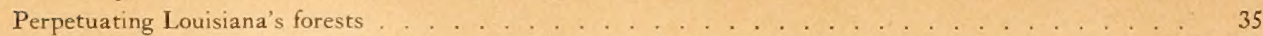

What forest owners and the forest-using industries can do . . . . . . . . . . . . . 35

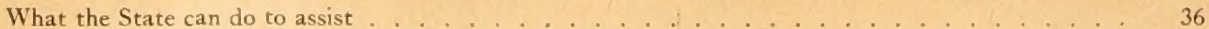

What the Federa! Government can do to assist ......................... 36

Appendix: Supplemental tables . . . . . . . . . . . . . . . . . . . 37 


\section{Introduction}

A

$\mathrm{N}$ INVENTORY of the timber resources of the

United States is especially needed at present on account of the increasing volume of forest products required for war purposes. This demand places an extra burden on the forests. To meet it, reasonably complete forest information is needed as a guide to meeting war requirements promptly and so handling the cutting as not to injure the forest permanently. Fortunately, Louisiana has been covered by a forest inventory and the publication of the results should aid its people materially in producing timber during and after the war.

What is now the State of Louisiana came into possession of the United States in 1803 as part of the Louisiana Purchase. It was then and is today a vast treasury of natural resourcessoil, for age, oil, water, and forest. The wealth of pine timber in Louisiana's forests was first estimated by the United States Census of 1880 (Sargent's Report on the Forests of

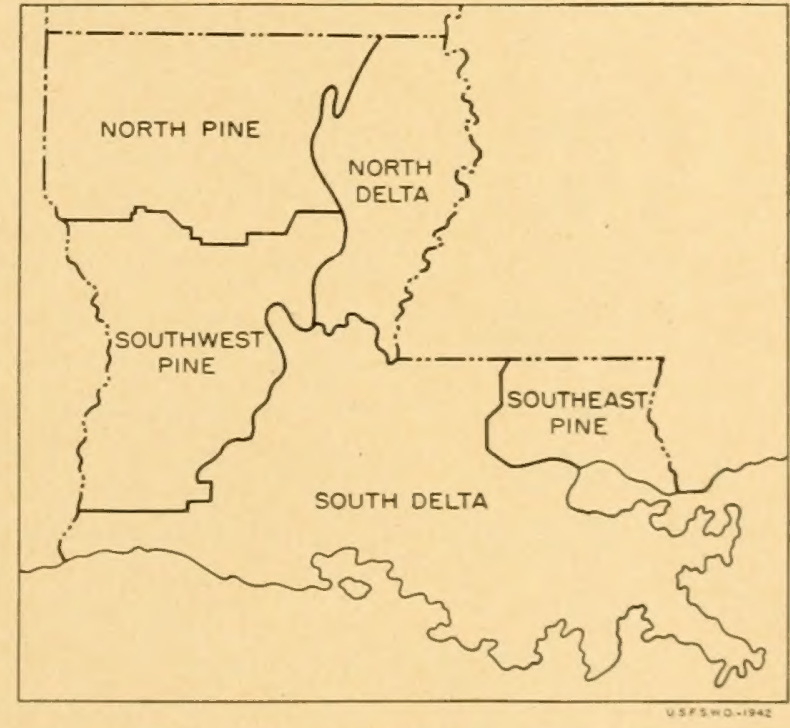

Frgure 1.-Forest Survey units in Louisiana. Throrghout this publication the data for the sousheast pine unit are combined with those for the soushwest unit.

but that there still remained some 41 billion board feet, of which 15 billion board feet was in pine. At the most conservative valuation, the stumpage sold and standing has brought or will bring to the State from 30 to 50 times the price originally paid France for the whole territory of the Louisiana Purchase.

Survey Methods

The first work of the Forest Survey in Louisiana began in 1934 and 1935, when trained foresters and timber estimators were brought in to cruise systematically the whole forest area. They used what is known as the line-plot method. They ran parallel compass lines 10 miles apart across the State and along these lines examined in. tensively about 35,000 sample plots spaced at intervals of 660 feet. These plots represented a satisfactory statistical sample of the entire forest-land area of the State. ${ }^{1}$ On each plot bearing a forest stand, tree measurements were made and
North America) at 48 billion board feet. Apparently no estimate of the hardwood was made at this time. In 1913 the Bureau of Corporations estimated the volume of pines and hardwoods as of 1909 at 119.8 billion board feet. Other estimates followed, but in the absence of field cruises they were mostly statements of opinion. Some measure of the inadequacy of these estimates and of the vastness of the total timber resource is afforded by available statistical records of 120 billion board feet of lumber produced in the State between 1880 and 1937. The only reliable inventory of what remains, made as a part of the Nation-wide Forest Survey, indicates that in 1938 Louisiana's magnificent stands of old-growth timber had been reduced to less than one-fourth of their original volume, recorded. From these field records, timber volume by species, the rate of timber growth, and the rate at which timber is lost through natural mortality were later calcu-

1 The Bureau of the Census in 1941 issued approximate land-area figures for the State of Louisiana and each of its purishes based on a complete remensurement since similar figures were published in 1936 . The remeasurement resulted in increases or decreases in the areas reported for individual parishes, even though there was no actual change in parish boundaries. Calculations of the area represented by each sample plot were based on the figures published in 1936. If the 1941 figures had beet available, she estimate of forest area for Louisiana would have been 9,200 acres less than that published in this report. The differences for most of the survey units are proportionately larger than that for the State as a whole; they are not lange enough, however, to affect significantly the consideration of the forest situation presented here. 
lated. Supplemental industrial studies made it possible to determine the volume of timber cut annually for industrial and domestic uses.

It was early recognized that there would be a demand for survey information for individual parishes (the Louisiana equivalent of counties), but the funds provided did not make this possible. Instead, the State was divided into five survey units of 2 to 11 million acres each, delimited principally by the character of the timber stands (fig. 1; also colored map at end of report) and fairly homogeneous as to forest, economic, and industrial conditions. Two of the units (north delta and south delta) consist of alluvial bottom lands of the Mississippi River, where the forest is almost exclusively hardwoods and cypress. ${ }^{2}$ The three others are made up for the most part of coastal flatwoods and rolling uplands, where the forests are characterized chiefly by pines. In the northwest unit (north pine), loblolly and shortleaf pines predominate; in the southwest and southeast pine units, longleaf pine. Because forest conditions in southeast and southwest Louisiana are similar and because the southeast unit is comparatively small, survey data for the two units have been combined in this report. The forest situation in each of the units has been discussed in previous reports. ${ }^{3}$

\section{Significant Findings}

\section{Economic Aspects}

Louisiana, once widely known for its magnificent stands of old-growth timber, still has a goodly portion of the forest resources of the lower South (fig. 2). The forests of the State now occupy 16.2 million acres, or 56 percent of the total land area of 29.1 million acres. The ratio of forested area to total area is highest ( 79 percent) in the south pine units, lowest ( 33 percent) in the south delta unit. Less than one-third of the land area of the State is in agricultural use.

Louisiana embraces 13 percent of the productive forest land in the region and is excelled only by Georgia in total volume of saw timber. It has more hardwood timber than

\footnotetext{
2 The term "cypress" is used throughout this publication to designate principally baldcypress (Taxodium distichum) but also pondcypress (T. ascendens). Similarly the term "tupelos" refers to the common "tupelo" of the lumber trade, water tupelo (Nyssa aquatica), and also to black tupelo ( $N$. sylvatica) and swamp tupelo ( $N$. biflora), both of which are known to the lumber trade as "black gum."

3 These reports are: Misc. Pub. 309, Forest Resources of the North Louisiana Delta; U. S. Forest Serv. South. Forest Expt. Sta. Survey Release 31, Forest Resources of Northwest Louisiana [Processed]; Survey Release 39, Forest Resources in the Longleaf Pine Region of Mississippi and East Louisiana [Processed]; Survey Release 42, Forest Resources of the South Louisiana Delta [Processed]; Survey Release 43, Forest Resources of Southwest Louisiana [Processed].
}

any other State in the Nation, amounting to nearly a quarter of the hardwood timber in the lower South. In 1937 Louisiana led the United States in production of hardwood lumber, manufacturing more than $1 \frac{1}{3}$ billion board feet of lumber of all kinds. Its six pulp mills also placed it first among the States of the lower South and fourth in the Nation in consumption of pulpwood. Since then a new pulp mill, the largest in the South, has been constructed at Springhill.

The forests of Louisiana serve as the foundation of industries normally employing more labor than any other industrial group except farm cropping. One-third of all workers employed in manufacturing receive their income directly from the preparation of forest products for the market. Most of the forest-industry plants are located in small towns and rural areas, where the majority of the people live. Thus, if the forest resource is properly managed and utilized, forest industries can make a direct and telling contribution to the prosperity of local communities.

The State has many natural advantages that favor timber growing and the manufacture of forest products. Many valuable timber species growing within its boundaries are readily marketable. Its soils are well adapted to timber growing. Adequate rainfall and long growing seasons prevail. The topography is characterized by level expanses and gentle slopes. Logging can be carried on throughout the year except in the delta and creek bottoms, where high water may impede it for a few weeks in winter and spring.

Favorable transportation facilities include an excellent system of hard-surfaced roads, which has reduced the cost of truck logging. The State has also several thousand miles of waterways, navigable during at least part of each year, for barging and rafting forest products. Its proximity to the lumber markets of the Middle West and the plains of Texas and Oklahoma, as well as the excellent facilities for export through New Orleans to world markets, provides ample outlets for these products.

In many parts of the State cut-over timberlands are being leased for oil development. Although the marsh areas are the main centers for trapping, fishing, and hunting, some forest lands are leased or owned for these purposes. Multiple uses for forest land, wherever they can be developed, may furnish an income to the landowner while his crop of timber is growing.

Notwithstanding the advantages possessed by Louisiana for timber growing and for continued operation of forest industries, the situation has certain unfavorable aspects. Chief among these is the prevalence of forest fires. While considerable progress in fire prevention and control has been made in many parts of the State, the 
constant attrition due to repeated burnings is a prime obstacle to timber cropping as a business.

The present forests are characterized by second-growth timber, much of which is below the minimum size for most industrial uses. These young forests do not have the high quality of the original oldgrowth stands; but because of the rapid development of the pulp industry and the gradual adjustment of the lumber and other forest industries to smaller timber, second-growth forests are of outstanding significance in the present and future economy of the State.

Largely as a result of past fires and logging methods, the forests contain too large a proportion of cull trees and trees of species not now in demand. The prompt removal of this material for fuel, chemical wood, and other low-value commodities for which it is suitable would materially improve the forest condition and the rate of growth of the remaining trees.

The forests in all parts of the State are generally understocked. In southwest Louisiana there are nearly a million acres of nonrestocking lands that formerly bore longleaf pine. Seed trees or clumps of advance reproduction are usually present on these lands but so widely scattered as to require many years to bring them back naturally to anything like good stocking. If this process is to be hastened, many of these lands must be planted.

Another important adverse factor is the relatively high taxes. Forest-land tax delinquency is most common among industrial owners, who according to rough estimates formerly owned nearly two-thirds of the forest land now adjudicated to the State for nonpayment of taxes.

\section{Forest Description}

Of the productive forest area of 16 million acres, 15.8 percent is in the longleaf pine type, 31.3 percent is in the shortleaf-loblolly pine and shortleaf-loblolly pinehardwood types, 5.8 percent is in upland hardwoods, and the remaining 47.1 percent is in bottom-land hardwoods.

Only 21 percent of the productive forest area supports old-growth forests, and heavy cutting has taken place on
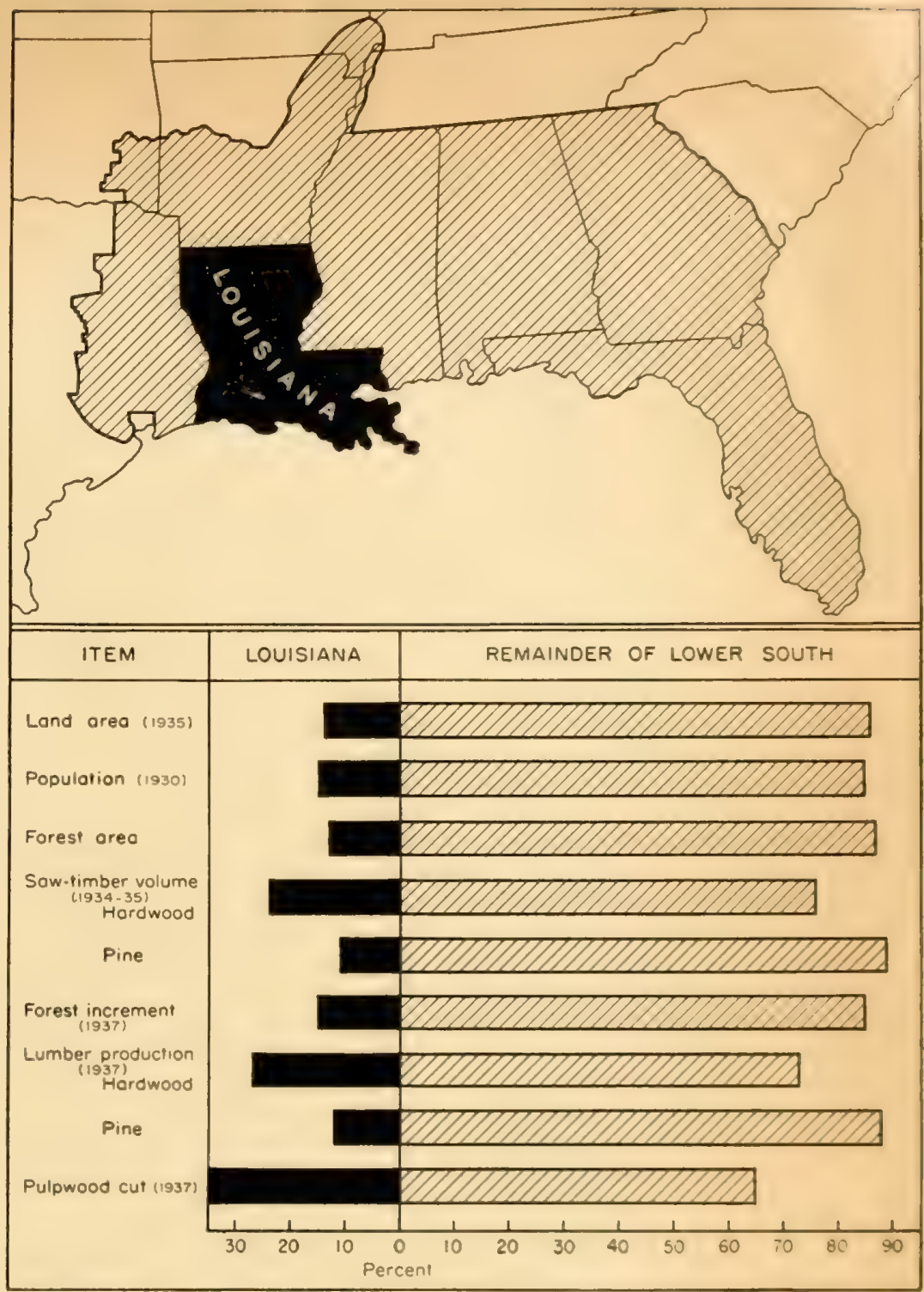

usiana ines

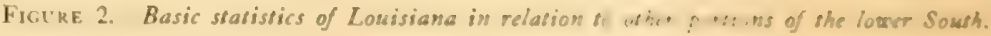

three-fifths of this portion. Second-growth sawlog-size stands are found on 41 percent of the forest area, and second-growth under-sawlog-size stands on 28 percent. Largely as the result of fire and indiscriminate cutting, approximately 10 percent of the forest area is virtually without forest growth.

The old-growth forests, mostly bottom-land hardwowds, are concentrated chietly in the north delea unit, where half the forest area supports old growth, nearly three fiths of which has been heavily cut. The smallest pro portion of old-growth forest area is that of the norrh pine unit -13 percent. Ot the clear-cut forest area, 83 percent is in the two south pine ...nts. 
About two-thirds of the saw-timber volume of 42.4 billion board feet is hardwood (including cypress), the remainder pine. Sixty percent of the hardwood saw timber is in the bottom lands of the Mississippi River Delta; the remainder, along with practically all the pine, occurs in the three upland survey units.

Loblolly pine makes up more than half the pine volume, shortleaf pine more than one-fourth. The hardwood and cypress saw-timber volume is about equally divided among three species groups: The oaks, the gums (sweetgum and tupelos), and miscellaneous species, including cypress.

Less than a fourth of the pine volume, but over half the hardwood and cypress volume, is in old-growth stands.

The total volume of sound material, including bark, is 237 million cords. It is composed of 62 million cords in under-sawlog-size trees, 101 million cords in sawlog-size trees, 44 million cords in the tops and limbs of saw-timber trees, and about 30 million cords in cull trees. The volume of sound wood, excluding bark, is 16 billion cubic feet.

\section{Special Forest Resources}

Nearly 30 million of the pine trees included in estimates of volume are suitable for poles and piles. This is about one-sixth of all pine trees 7 to 19 inches d.b.h. Nearly two-thirds of these, however, would make poles or piles no longer than 25 feet.

In 1935 the 2 south pine units contained approximately 10 million round longleaf and slash pine trees 9 inches d.b.h. or larger and suitable for turpentining. In the 1937-38 season, 4 gum turpentine stills were operating in the State; production totaled 2,070 units-the smallest quantity since about 1880 .

About $71 / 2$ million tons of stump wood (on a blasting basis) was available in 1935 for the production of wood naval stores; 58 percent was on clear-cut areas supporting 14 or more stumps per acre. In 1937, three wood naval stores plants were in operation; they consumed about 121,000 tons of seasoned pine stumps and top wood and produced 7 times as much turpentine as the gum naval stores industry.

\section{Forest Industries}

Employment provided by the forest industries in 1937 totaled 14 million 8-hour man-days. Lumber manufacture alone accounted for more than 40 percent of this employment; fuel-wood production was second. The pulp industry furnished nearly half as much employment as the lumber industry.
In 1937 , there were 557 sawmills in the State; 10 percent of these had capacities of 40,000 board feet or more per 10-hour day and produced 68 percent of the lumber sawed. The number of mills increased to 565 in 1940, but the number of mills of 40,000 board feet and larger capacity declined from 58 to 45 . There were also, in 1937, at least 88 nonlumber forest-industrial plants; most important of these were the 6 active pulp mills, which consumed more than 700,000 cords of pulpwood.

\section{Forest Increment and Drain}

In 1937, a peak year of lumber production, the annual cut for all purposes from the saw-timber component of the forest was 2,300 million board feet, which exceeded the net increment by 400 million board feet. Subsequent lumber production has been less than in 1937, so that the deficit in later years is almost certain to have been less. Even so the cutting is chiefly concentrated on the larger, higher quality trees, while the increment is mostly in the smaller less-marketable trees. Furthermore, present cutting practices are gradually reducing the stocking of timber stands.

Net increment of the entire growing stock of sound trees 5 inches d.b.h. and larger was about 7 million cords. The cutting of about 6.3 million cords for commodities left 0.7 million cord as surplus. All this excess of increment over commodity drain measured in cords was in hardwoods and cypress, where increment exceeded drain by nearly a million cords; in the pines drain exceeded increment by about 264,000 cords. Mortality loss was equivalent to 15 percent of total growth in cords for pines and 31 percent for hardwoods and cypress.

Because the depletion in saw-timber material is more than offset by the accretion in material below saw-timber size, the forest volume as a whole is slowly building up, but this increase is in sizes and of species not now readily marketable. Growth processes and proper cutting practices can in time remedy the developing deficiency in timber of saw-timber size, and changes in market requirements may make possible the utilization of species not now moving easily on the market. Nevertheless, shrinkage in the aggregate forest industrial set-up, due to lack of suitable timber supply, seems inevitable. If the forests are correctly handled, this shrinkage will be only temporary.

\section{Adjustments Needed}

The primary objective of forestry is to build up and maintain the quantity and quality of the forest growing stock so that forest industries can have adequate supplies of raw material. The accomplishment of this aim involves definite action by land owners, the State, and the Federal Government. 
The private owner must so handle his forest land that it will grow marketable timber at a reasonable rate, and in so doing he may profit by the counsel and assistance of State and Federal agencies. Forestry practices are already being applied on more than a million acres of private forest land in Louisiana. Wherever private owners are unwilling to apply these practices, public controls are necessary to make sure that timber is grown to meet future industrial needs.

Specifically, private owners, in active cooperation with the Federal and State Governments, should work toward the goal of fire protection for all their forest lands. As a primary step toward increasing in volume and quality the growing stock of their lands, they should harvest their timber according to the principles of sound forest practice and integrated use. Where possible, they should develop the supplementary uses of private forest land, such as hunting, trapping, and fishing, in order to obtain additional income from the property. To improve marketing conditions and reduce the cost of technical assistance, the smaller forest-land owners should consider forming regional cooperatives, which could employ technical advisers to work for the common interests of the members.

The State Government should first of all provide sufficient appropriations, in cooperation with the Federal Government under the Clarke-McNary Act for complete fire protection for all the forests within its borders. It should augment and intensify its forestry extension activity through expansion of its Division of Forestry and its Agricultural Extension Service. It should provide for additional instruction in forestry in the public schools. Its system of demonstration forests should be extended and should be so distributed throughout the State as to serve the maximum number of the smaller forest-land owners. The State planning agencies should consider carefully the possible contribution of the forests to the industrial planning program now under way. The forest resource should be woven into the industrial pattern of each section of the State. Such a program would mean greater income and more stable social conditions.

Since continuity of forest-land ownership is generally a prerequisite for sustained-yield forest management, State tax laws and parish taxation policies should be examined and where necessary revised to remove excessive burdens; where the difficulty is inequitable administration of the law, the taxation machinery should be reorganized in order to assure proper application. The State should also strive for better observance of the property rights of private forest-land owners, in order to reduce timber theft, incendiarism, and other forms of trespass and damage.

The Fedeal Government should make increased $514449-43-2$ appropriations for cooperative fire protection under the Clarke-McNary Act, so as to contribute its share of the fire-protection costs under an expanded program and match increased outlays by the State and private owners.

Federal financial and technical assistance to the extension agencies of the State should be continued and, if possible, expanded.

New administrative facilities should be established, or the scope of present facilities extended, so that long-term low-interest-bearing loans may be made to forest enterprises.

Federal purchases of forest land should be continued, mainly in areas where farm cropping tends to decline and where soil or forest conditions make the opportunities for private forest management appear unattractive.

Appropriations should be made for research on problems concerning hardwood forests, both in the Delta bottom lands and on upland areas. About 1945, the Federal Government should take a new inventory of the forest resources, in cooperation with the State, to serve as a basis for more detailed plans for development of the forest resource.

\section{Definitions of Terms Used}

Throughout this report, statistics given are as of the time of the field survey, $1934-35$, unless otherwise specitied. The statistical tables appear as an appendix, beginning on page 37 .

To facilitate a thorough understanding of the forest situation discussed, technical and unusual terms used are defined, as follows:

Area

Lower South.-States and parts of States in the southern Forest Survey territory (fig. 2).

Land Use Classes

Productive forest land.-Forest land that has the qualities essentral for the growth of commercial timber.

Nonproductive forest land.-Forest land that does not have all the qualities essential for the growth of commercial] timber.

Cultisated agricultural land. - Land being uset for farm or orchard crops, or showing evidence of having been so used during the preceeding 2 years. New croplat and is cultivated land converted from torests within 5 years prior to survey.

Idle agriculdural land.-Cultivated land that has heen idle for 2 vears or more bue is not dassificat as abankined. 
Improved pasture.-Cleared or open land under fence, used primarily for grazing, upon which an effort has been made to maintain a sod.

Abandoned agricultural land.-Formerly cultivated land that shows distinct signs of having been abandoned for farm crop production, but on which no attempt has been made to maintain improved pasture conditions.

Other areas.-Areas included within the corporate limits of cities and towns, and suburban and industrial sections; power, rail, and highway rights-of-way; marsh; nonmeandered waterways; and prairie.

\section{Species Groups}

Pines.-Turpentine: Longleaf and slash pines (Pinus palustris and $P$. caribaea). Nonturpentine: I.oblolly, shortleaf, and spruce pines ( $P$. taeda, $P$. echinata, and $P$. glabra). Included with nonturpentine pines are eastern redcedar (Funiperus virginiana) and Atlantic white-cedar (Chamaecyparis thyoides).

Hardwoods.-Soft-textured: Sweetgum ${ }^{4}$ (Liquidambar styraciflua), tupelos (Nyssa spp.), southern sweetbay (Magnolia virginiana australis), red maple (Acer rubrum), southern magnolia ( $M$. grandiflora), and species of similar texture. Firm-textured: Red oaks and white oaks (Quercus spp.), ashes (Fraxinus spp.), elms (Ulmus spp.), hickories (Hicoria spp.), and species of similar texture.

Cypress.-Baldcypress and pondcypress (Taxodium distichum and $T$. ascendens). Except where specified otherwise, cypress is included with the soft-textured hardwoods.

\section{Forest-Type Groups}

In pine types, the pine species constitute at least 75 percent of the board-foot volume in sawlog-size stands and at least 75 percent of the dominant and codominant stems in under-sawlog size stands; in hardwood types, hardwood species are similarly represented. In pinehardwood types, neither species group constitutes so much as 75 percent of the board-foot volume in sawlog-size stands or sor much as 75 percent of the number of dominant and codominant stems in under-sawlog-size stands.

Longleaf and slash pines.-Includes the following forest types: Longleaf pine, longleaf-slash pine, longleaf-loblolly pine, longleaf-shortleaf pine, longleaf pine-hardwood, slash pine, slash pine-cypress, and turpentine pine-hardwoods.

Shortleaf-loblolly pines and shortleaf-loblolly pines-hardwoods.-Includes the following forest types: Shortleaf pine, shortleaf-loblolly pine, shortleaf pine-hardwoods, loblolly pine, loblolly pine-hardwoods, nonturpentine pine, nonturpentine pine-hardwoods, and pine-hardwood.

\footnotetext{
4 The heartwood of this species is known to the lumber trade as redgum and the sapwood as sapgum.
}

Upland hardwoods.-Includes upland hardwood and scrub oak-scrub hardwood types.

Bottom-land hardwoods.-Includes the following forest types: Sweetgum-water oak, sugarberry ("hackberry")elm-ash, overcup oak-water hickory ("bitter pecan"), cypress-tupelos, scrub coastal hardwoods, scrub coastal cypress, water oaks, mixed oak-mixed hardwoods, and a generalized bottom-land hardwood type characteristic of the smaller stream bottoms outside the Mississippi River Delta.

\section{Forest Conditions}

Old-growth stands.-Stands composed predominantly of trees of saw-timber size that, with regard to age, size, form, clearness of stem, density of grain, and quality of prospective yield, have the characteristics of the original mature stands found in the region.

Old-growth uncut.-Old-growth stands from which less than 10 percent of the volume has been cut.

Old-growth partly cut.-Old-growth stands from which 10 percent or more of the volume has been cut, but in which the remaining old-growth saw timber contains at least 1,000 board feet per acre of hardwood or pine and hardwood mixed, in the Mississippi River Delta, or 600 board feet per acre of pine or pine-hardwood mixed, outside the Delta.

Second-growth sawlog-size uncut.-Second-growth sawlogsize stands from which less than 10 percent of the sawlogsize trees have been cut, and in which the remaining saw timber contains at least 600 board feet per acre.

Second-growth sawlog-size partly cut.-Second-growth sawlog-size stands from which 10 percent or more of the sawlog-size trees have been cut, but in which the remaining saw timber contains at least 400 board feet per acre.

Second-growth under-sawlog-size.-Second-growth stands composed predominantly of under-sawlog-size trees at least 1.0 inch d.b.h. ${ }^{5}$ The saw timber present totals less than 600 board feet per acre in uncut stands and less than 400 board feet per acre in partly cut stands.

Reproduction.-Areas on which the forest growth does not meet any of the foregoing definitions but that bear per acre more than 80 seedlings or sprouts of commercial species less than 1.0 inch d.b.h.

Clear-cut.-Cut-over areas on which forest growth is insufficient to justify classification as old-growth partly cut, second-growth, or reproduction.

Class $A$ forests.-Saw-timber forest areas in the Mississippi Delta units that bear $1 \mathrm{M}$ board feet or more per acre of high-grade saw-timber material, regardless of species.

${ }^{5}$ D.b.h. = diameter at breast height, or $4 \frac{1}{2}$ feet. 
Class B forests,-Forest land in the Mississippi Delta survey units not classified as class $\mathrm{A}$ areas.

\section{Tree Classes}

Sawlog-size iree-A tree with the following minimum diameters outside bark: In the Mississippi River Delta units, hardwood and cypress 13.0 inches at $4 \frac{1}{2}$ feet above the ground (churn-butted trees, at $21 / 2$ feet above the butt swell); in the pine units, cypress trees 9.0 inches at $4 \frac{1}{2}$ feet above the ground or at 23/2 feet above the butt swell; all pines (except turpentined longleaf and slash pine) 9.0 inches at $4 \frac{1}{2}$ feet above the ground; turpentined longleaf and slash pine 9.0 inches at 10 feet above the ground; and hardwoods 13.0 inches at $4 \frac{1}{2}$ feet above the ground.

Saw-timber tree.-A sawlog-size tree that contains at least one sound $\log 12$ feet long or that has at least 50 percent of its gross volume in sound material.

Sound or good tree.-A sawlog-size tree that is, or an under-sawlog-size tree that gives promise of becoming, a saw-timber tree.

Cull tree.-A sawlog-size tree that is not a saw-timber tree, because of poor form, crook, knots, extreme limbiness, decay, or other defects; or an under-sawlog-size tree that for similar reasons will not become a saw-timber tree.

High-quality saw timber.-Logs or bolts of the quality commonly accepted at full value on the open market by the lumber, veneer, and cooperage industries. Material in such species as honeylocust, cedar elm, and water hickory was considered high grade if its quality was equivalent to that accepted in species ordinarily in greater demand.

Low-quality saw timber.- - Logs or bolts not of the quality to meet the specifications for high-quality saw timber.

\section{Turpentine-Tree Conditions}

Round.-Longleaf and slash pine trees that have never been worked for naval stores.

Working - Longleaf and slash pine trees being worked for naval stores.

Resting.-Previously worked longleaf and slash pine trees that are resting prior to the working of back faces.

Worked-out.-Longleaf and slash pine trees on which as many faces have been worked as the trees will stand.

\section{Grows and Drain}

Growing stock.-That part of the timber stand on which growth is computed. Only thrifty, well-formed trees are included. Boardfoot growing stock includes only the sawlog portion of saw-timber trees. Growing stock in cords and in cubic feet includes, in addition to saw timber, sound under-sawlog-size trees and upper stems of sawlog-size pine trees.
Growth.-As used in this report, growth represents the aggregate growth during the year of all sound trees of merchantable size, plus the volume of small trees reaching merchantable size, before mortality is deducted.

Mortality loss.-The aggregate loss of sound trees during the year through natural death, fire, insect damage, disease, windthrow, and other factors, excluding removal for use.

Net increment.-Total growth minus mortality.

Merchantable volume. - The volume in board feet of all sawlog-size trees. Merchantable volume changes during a given period by an amount equal to the growth of individual trees already of merchantable size plus the volume of small trees attaining merchantable size and minus the volume lost through death.

Commodity drain.-All growing-stock material removed from the forest by cutting, including woods waste.

Woods waste.-Portions of good trees included in the survey inventory but left in the woods when the trees are cut.

Cull.-Portions of sound trees unmerchantable owing to fire scars, rot, shake, insect damage, large knots, fork, crook, excessive sweep, etc.

\section{Forest Management and Utilization}

Selective cutting.-Removing as many as possible of the defective, unpromising trees, along with a portion of the mature timber, and leaving for future growth the more rapidly growing young timber.

Integrated use.-Cutting all of the timber that it is proper to cut at one time, and then sorting the material for the use to which its size, quality, and species best adapt it (as high-quality red gum logs for veneer and lower-quality oak for railroad ties).

\section{Units of Measure}

Lumber tally.-The International log rule was used in the inventory to approximate lumber tally. ' 'se was made of the following formula for a 16-foot $\log$, with allowances for a $1 / 2$-inch taper in 4 feet and for a $1 / 4$-inch saw kerf and 1/16-inch shrinkage: $y=0.796 D^{2}-1.35 i D-1.23$. Mill cut was used for lumber production figures.

Cord. - Standard stack ( 4 by + by 8 feet), bark included.

Cubic foot.-All cubic-foot volumes represent solid wout only, excluding bark.

Naval stores unis. The equivalent of 1 barrel (5) gallens) of turpentine and $3 \zeta$ barrels ( $\overline{(}(x)$ pounds, grens) of rosin.

Ton of stump wood-Represents 5 well-seisoned olitgrowth longleaf pine stumps, removed by blasting.

Diameser class. - The 1(1)-inch diameter class, for example, includes trees from 9.0 to 10.9 inches $d . b$. h.; the 12 -inch class, trees from 11.0 to 12.9 inches. 


\section{Forest Description}

I

$\mathrm{N}$ THE main the forests of Louisiana are characterized by young stands, three-fifths of which are of sawlog size and nearly all of which have grown rapidly. Nearly 10 percent of the area classified as forest land is practically devoid of forest cover; in this respect no State of the lower South except Florida has a worse situation. Equally significant is the fact that, judged by the number of trees that the soil could profitably support under reasonably good forest management and with protection from forest fires, most of the forest stands in virtually all forest types and conditions throughout the State are understocked. Largely as a result of repeated fires and past cutting practices, nearly all stands include many cull and defective trees and many trees of inferior species that are not readily marketable. Species for which markets need to be developed in order that their considerable volume may find profitable use include the post oak (2uercus stellata) of the uplands and the overcup oak (2. lyrata), water hickory (Carya aquatica), and sugarberry or "hackberry" (Celtis laevigata) of the bottom lands.

Forest fires are all too prevalent. In 1940, half a million of the $8 \frac{1}{2}$ million acres of forest land in the State without organized protection, or 6 percent, is estimated to have been burned over by about 2,000 fires. On the $71 / 2$ million acres of forest land that was under fire protection, more than 3,100 fires, caused chiefly by the carelessness of users of the forest, burned only 129,000 acres, or 1.7 percent.

The forests of Louisiana fall into two general type categories-hardwood forests of the alluvial flood plains adjacent to the principal streams and pine-hardwood forests of the uplands (see forest-type map inside rear cover). In the latter category are three distinct type groups, longleafslash pines, upland pine-hardwoods, and upland hard-
Figure 3.-Forest area of surcey unils by forest-type group, 193t-35.

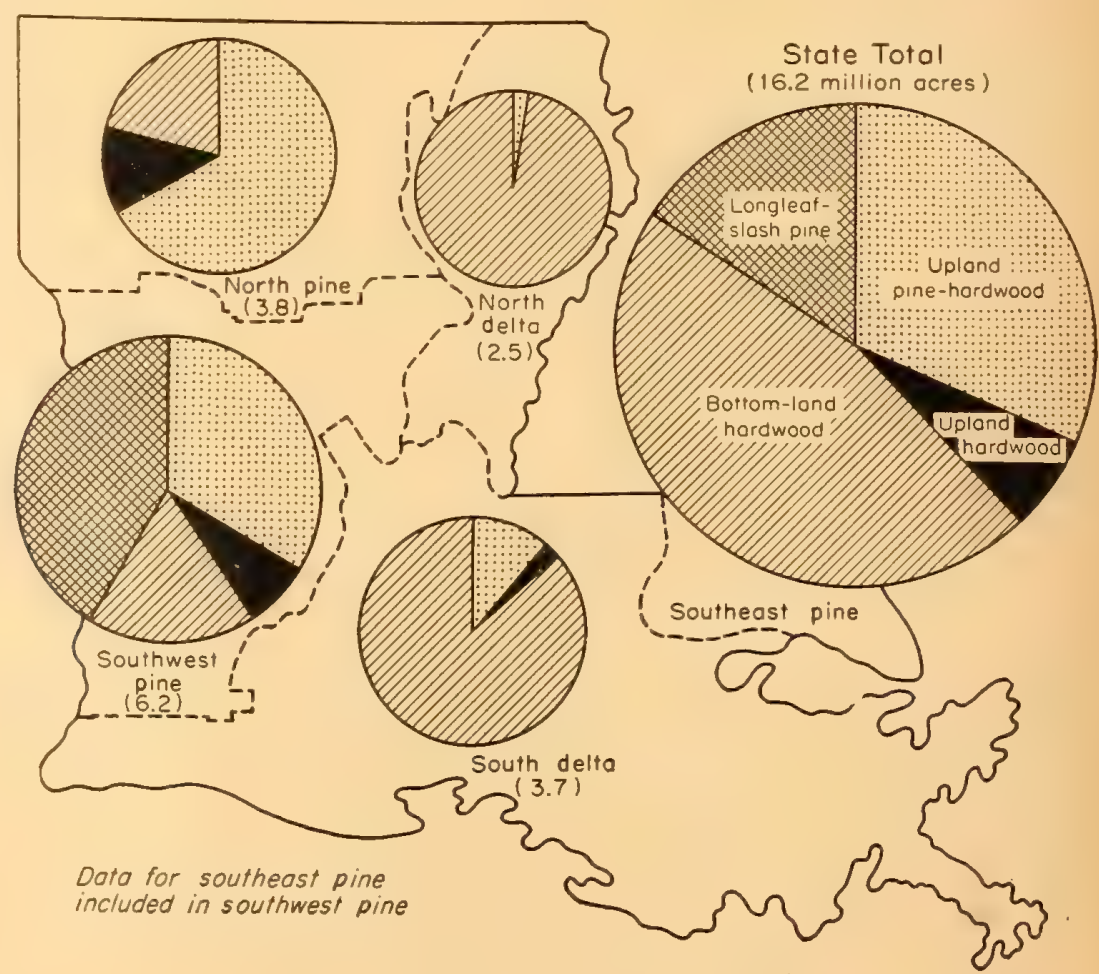


Figure 4.-Forest area of sursey units by forest condition, 1934-35.

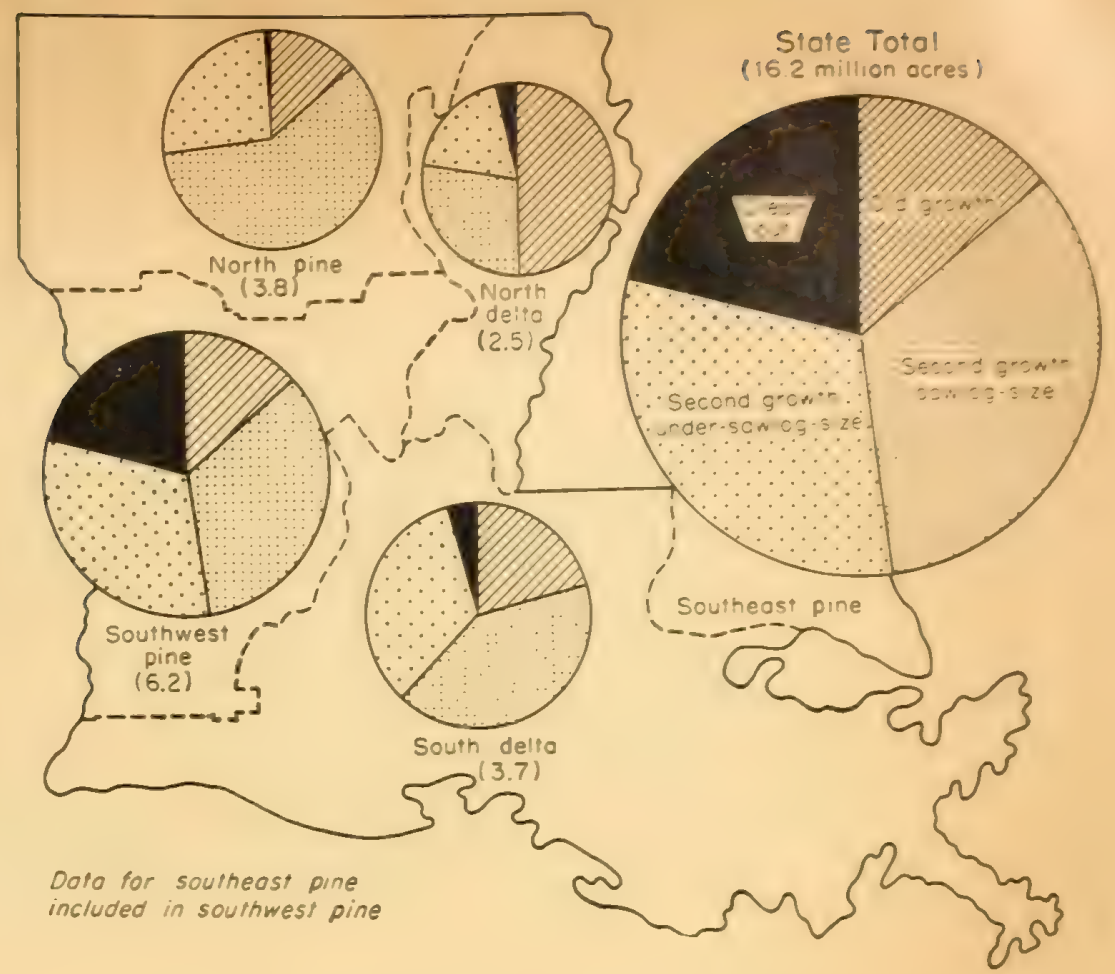

woods (tables 1 and 2 and figs. 3 and 4). For detailed statement of forest areas in the various type groups and forest conditions, see table 16 in the Appendix.

\section{Bottom-Land Hardwood Forests}

Lovisiana has 7,627,300 acres of bottom-land hardwoods, more than any other State of the lower South. Seventysix percent is in the alluvial lands of the Mississippi River Delta, the remainder chiefly in the bottoms of the Red, Ouachita, Calcasieu, Sabine, and Pearl Rivers and other streams of the rolling uplands.

Typically, these hardwood forests contain a dominant stand of overmature trees, with an understory of immature trees of varying sizes and ages (fig. 5). In such a forest, industrial cutting operations usually remove only the larger and higher-quality trees, leaving well-stocked stands of immature trees of varying ages and mature trees of the species less desirable for industrial use (fig. 6).

Of the 36 percent of the bottom land that still bears old-growth timber, nearly half is in the north delta unit. ()n approximately three-fiths, high-quality timber has been cut for lumber, veneer, and cooperage stock. About is percent of the bottom-land forest area is taken by second growth stands that have reached sawlog size, and 26 percent by other second-growth. More than half of the second-growth area is in the south deltat unit. Only atout 3 percent of the bottom land forest area is classed as clear-
TABLE 1.-Forest area classified by forest-sype groups, $19.3+351$

\begin{tabular}{|c|c|c|c|c|c|}
\hline Survey unit & $\begin{array}{c}\text { Forest } \\
\text { area }\end{array}$ & $\begin{array}{l}\text { Bottom- } \\
\text { laad } \\
\text { hard- } \\
\text { woods }\end{array}$ & $\begin{array}{l}\text { Ipland } \\
\text { hard. } \\
\text { woods }\end{array}$ & $\begin{array}{l}\text { Upland } \\
\text { pune } \\
\text { hard- } \\
\text { woods }\end{array}$ & $\begin{array}{c}\text { Longloaf } \\
\text { slach }\end{array}$ \\
\hline & $\begin{array}{c}\text { Million } \\
\text { a... }\end{array}$ & tra & theirle: & $1 \ldots$ & lines: \\
\hline Xirt $+1,1 \cdot{ }_{1}$ & : : & 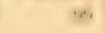 & $\theta$ & I & 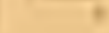 \\
\hline South delts..... & 3.7 & 90 & 2 & 8 & 0 \\
\hline$\lambda e^{+1} ; \cdots$ & is & Ai & 13 & in: & . \\
\hline 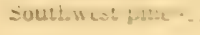 & L. & 1: & 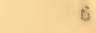 & $\stackrel{2}{2}$ & 4. \\
\hline All units.. & 16,2 & 47 & 6 & 31 & 16 \\
\hline
\end{tabular}

Det ailed data are given in table 16, Apremilex.

:Includes values for southeast pine unut

TABLE 2-Forest areas classified by faress condition, $10.7-353$

\begin{tabular}{|c|c|c|c|c|c|}
\hline \multirow[b]{2}{*}{ Survey unit } & \multicolumn{2}{|c|}{ Olal sroweth } & \multicolumn{2}{|c|}{ Sevment arowith } & \multirow{2}{*}{$\begin{array}{l}\text { "kear } \\
\text { cut }\end{array}$} \\
\hline & I"neut & $\begin{array}{c}\text { Partly } \\
\text { cut }\end{array}$ & $\begin{array}{l}\text { Silow } \\
\text { sire }\end{array}$ & $\begin{array}{l}\text { Conder } \\
\text { sawling } \\
\text { cinow }\end{array}$ & \\
\hline & temese & Firsones & H:mens & $y=$ & t \\
\hline Sintle atis & $\therefore$ & 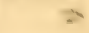 & a & a & \\
\hline South deles...... & 7 & 13 & 43 & 38 & 4 \\
\hline $1+\cdots 1+1$ & 6 & : & $\cdot$ & 5 & 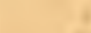 \\
\hline soutitumest frute . & s & $v$ & 3 & sis & 4 \\
\hline All units.. & 8 & 12 & 42 & 36 & 1 \\
\hline
\end{tabular}

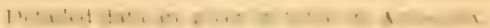

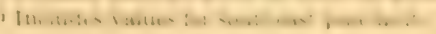




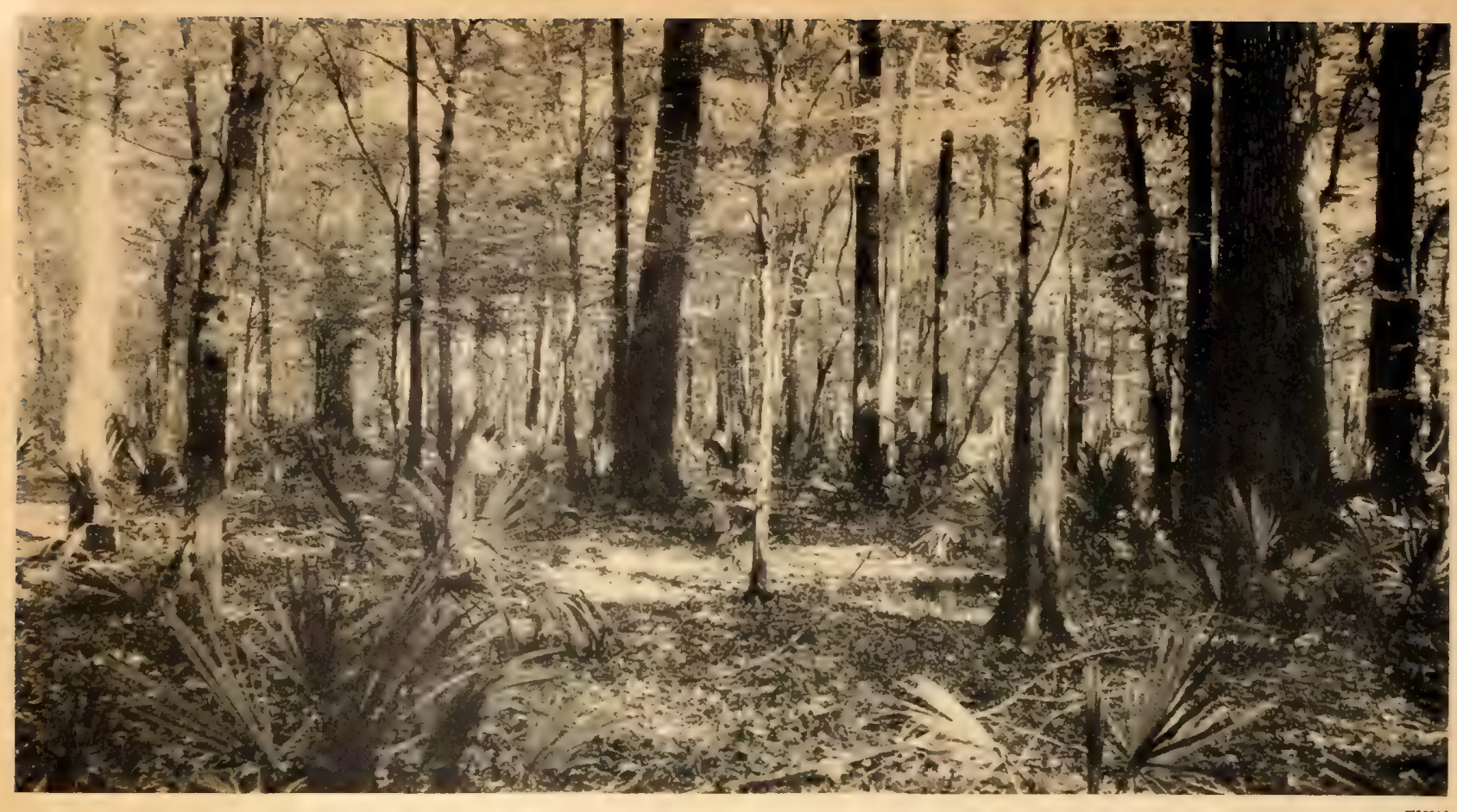

FIGURE 5.-Typical old-growth bottom-land hardwood stand with understory of immature trees. Madison Parish.

cut, and included in this category is a small area of nonproductive forest bearing a woody growth of noncommercial species such as common adelia or "swamp privet" (Forestiera acuminata), planertree (Planera aquatica), and buttonbush (Cephalanthys occidentalis).

Much of the uncut old-growth bottom-land hardwood timber is held in large tracts by industrial owners. One of the more outstanding of these, supporting an exceptionally large volume of high-quality timber, is the Singer tract near Tallulah, in Madison Parish. Although recent sales have reduced its area by half, it still contains about 40,000 acres and is one of the large areas of old-growth hardwood timber in the South. The forest on this tract, frequently three-storied, is composed of a mixture of important hardwood species including sweetgum (redgum), tupelos, and cypress. Most of the old-growth timber is overmature and includes considerable cull. On the area recently sold, although most of the merchantable timber is being cut, the residual stand is fairly well stocked, owing to the considerable volume of second-growth timber present. In the Grand Lake region north of Morgan City are vast areas of tupelo (chiefly water tupelo, or "tupelo gum"). Although this timber is not readily marketable at present much of it may be used in the future for cellulose products.

The forest land in the bottoms has not been classified according to site quality - that is, forest-producing capacity-because nearly all of it rates high in this respect. Most of the bottom-land areas are believed to have a forest-producing capacity considerably above the average for hardwood sites in the upland and mountainous parts of the South. The exceptions are the poorly drained backwater areas of waxy clay soils in the bottom lands and on the terraces, which support stands of the overcup oakwater hickory type. Even when drained, these soils are usually undesirable for agirculture.

\section{Rolling Upland Forests}

Of the three principal types of forests on the rolling uplands, which in all occupy $8 \frac{1}{2}$ million acres, the longleaf and slash pine forests are restricted to the southern part. Upland pine-hardwood and upland hardwood also occur in the southeast and southwest pine units, but more extensively in the northwest pine unit. The longleaf-slash pine types occupy 30 percent of the upland forest area, the shortleaf-loblolly pine hardwood type 59 percent, and the upland hardwoods 11 percent.

Longleaf pine originally grew in practically pure stands chiefly in Vernon, Beauregard, Allen, Rapides, and adjoining Parishes in the southwest part of the State, and in Washington and St. Tammany Parishes in the eastern tip. Here was once found some of the choicest virgin longleaf pine timber of the South. Entire sections are reported to have averaged more than $20 \mathrm{M}$ board feet per acre, Scribner scale. Like parks or groves, the virgin longleaf pine forests had little or no undergrowth or reproduction (fig. 7); and the trees, which were tall and clear- 

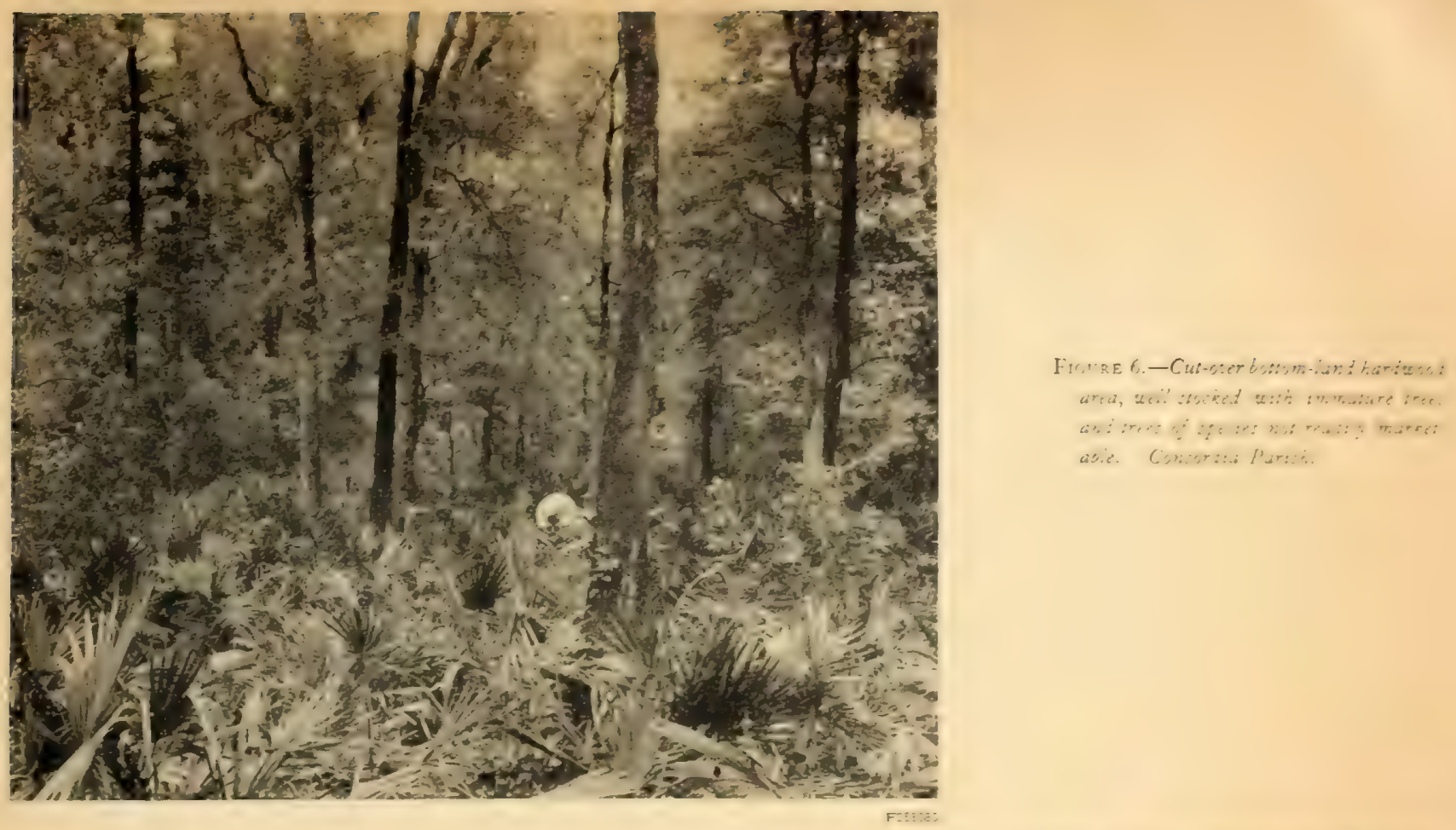

boled, produced lumber of dense grain and high quality. The original pine forests of the southeast were essentially similar, except that slash pine often occurred in association with longleaf pine.

The longleaf-slash pine types still characterize more than $2 \frac{1}{2}$ million acres of the upland forest area but are gradually losing ground. They are being replaced by loblolly pine, which produces seed more frequently and abundantly than longleaf pine and germinates better under existing seedbed conditions. This extension of loblolly pine is particularly evident in Natchitoches and Sabine Parishes in the southwest pine unit, and is common also in the southeast pine unit.

Of the present longleaf-slash pine forest area only 3 percent supports uncut old growth. Most of this is in Rapides and Vernon Parishes and is held by large companies. Partly cut old-growth stands occupy 5 percent of the area. Second-growth stands have reached sawlog size on 11 percent of it, and second-growth stands under sawlog size occur on 32 percent. The remaining 49 percent of the type-group area, mostly in Vernon, Beauregard, Rapides, Allen, and Calcasieu Parishes, has been clear cut and so seriously damaged by fire and grazing that practically no reseeding has taken place.

Occasionally the clear-cut areas occur as large barren blocks with practically no seed trees or reproduction (fig. 8). More commonly, they contain a few scattered seed trees or potential seed trees (fig. 9). In southwest
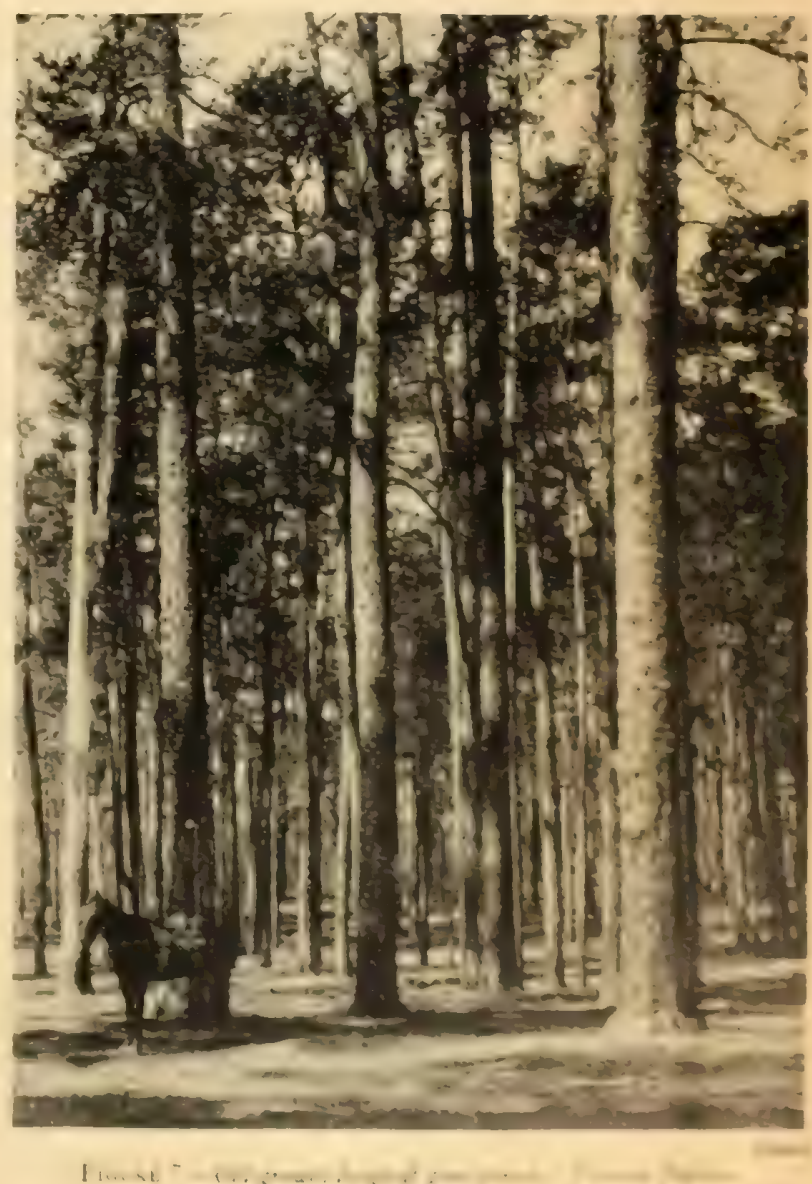

ra 


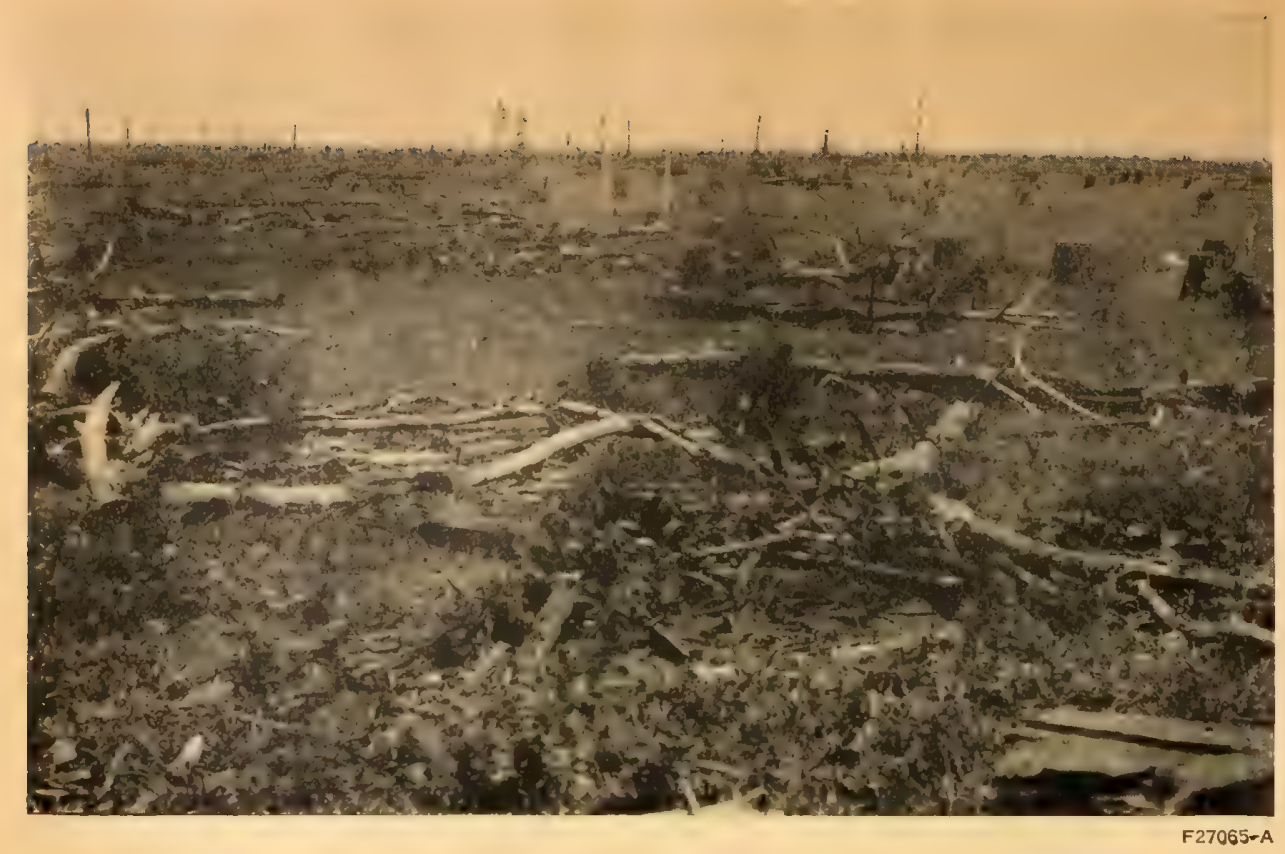

FIGURE 8.-Clear-cut longleaf pine area with practically no seed trees or reproduction. Lasalle Parish.

Louisiana nearly half the clear-cut area bears one or more seed trees per acre, and so, if adequately protected from fire and from grazing by hogs, sheep, and goats, may eventually produce another crop of timber through natural restocking. This restocking would require many years, however. For a prompt return to productive forest conditions, tree planting on a large scale would be necessary.
Almost twice as extensive as the turpentine pine forests are those of the shortleaf and loblolly pine types, which occupy 5 million acres. Each of these species is found in pure stands, but they more often occur together or in mixture with hardwoods. Shortleaf pine is most commonly found in the northwest section, but loblolly pine is important in all the pine survey units. The forests of these

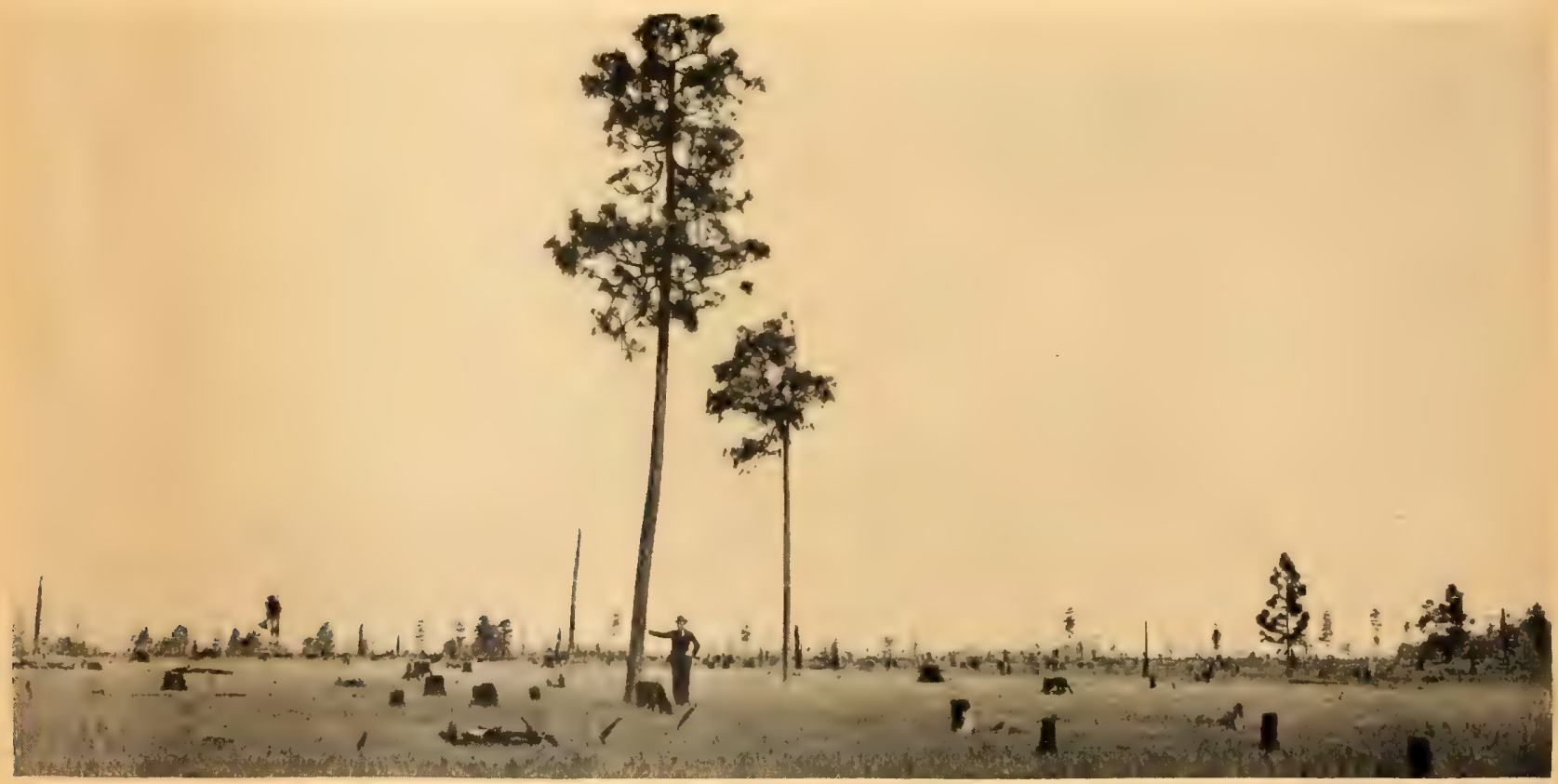

FIGURE 9.-Cut-over longleaf pine land with scattered seed trees and adcanced reproduction. Allen Parish. 
types have nearly all been cut over; only on slightly more than 100,000 acres, or 2 percent of their original area, does old growth remain uncut. However, because shortleaf and loblolly pines reseed the land readily and grow quickly, and because an understory of scattered young pines was usually left when the old-growth forests were cut over, most of the cut-over forest acreage of these types has restocked and two-thirds of it is now covered with stands of sawlog size.

The remaining 0.9 million acre of forest land in the rolling uplands bears chiefly upland hardwoods, among which are hickories and red, post, and white oaks. A few scattered pines are intermixed. These stands, many of which are uneven-aged, generally occupy scattered, relatively small tracts. Less than 10 percent of the area bears uncut old-growth timber, and very little of the rest failed to restock. Of importance in management is the fact that although the upland hardwood forests contains many of the same species found in the bottom-land forests, the individual trees are usually inferior in quality to those growing on the bottom lands.

During the last 20 years more than 169,000 acres of cutover forest lands and old fields in Louisiana have been planted to slash, longleaf, and loblolly pines; on $148,0(0)$ acres of this total the planting is classified as successful. The Federal Government is credited with planting 91,000 acres; the State with 4,600 acres; other public agencies, 164 acres; farmers and other nonindustrial private landowners, 19,200 acres; and industrial organizations, 54,200 acres. With the exception of nearly 30,000 acres of planted pine on the land of Gaylord Container Corporation in Washington Parish, most of the plantations are in southwest Louisiana. Several of the older ones are now being thinned commercially for pulpwood. 


\section{Economics of the Forest Situation}

Land Use

A LTHOUGH Louisiana has a long agricultural history, forests at present occupy 56 percent of its total land area and agricultural land constitutes only 28 percent of the total (table 3). Marshland, and the small areas occupied by cities, towns, roads, railroads, etc., make up the remaining 16 percent of the State's land area.

The south delta survey unit, which contains nearly all the marshlands, has a considerably smaller percent of its land area in forest than the remainder of the State (fig 10). Southeast and southwest Louisiana have greater proportions of their areas devoted to forests than the other survey units.

The land area used for growing cotton, by far the leading farm crop, has gradually diminished from 1,945,000 acres in 1929 to $1,089,000$ acres in 1939 . Although a part of the 856,000 acres lost has gone into other forms of agricultural use, much of it is now idle or abandoned.

TABLE 3-- Total area classified by land use in Louisiana, $1934-35^{1}$

\begin{tabular}{|c|c|c|c|c|}
\hline Survey unit & $\begin{array}{l}\text { Total } \\
\text { area }\end{array}$ & $\begin{array}{l}\text { Forest } \\
\text { land }\end{array}$ & $\begin{array}{c}\text { Agricultural } \\
\text { land }\end{array}$ & $\begin{array}{l}\text { Other } \\
\text { uses }\end{array}$ \\
\hline North delta....... & $\begin{array}{l}\text { Million } \\
\text { acres } \\
\text { 3. } 6\end{array}$ & $\begin{array}{r}\text { Percent } \\
68\end{array}$ & $\begin{array}{r}\text { Percent } \\
30\end{array}$ & ${ }_{2}$ Percent \\
\hline South delta........ & 11.5 & 33 & 32 & 35 \\
\hline North pine.......... & 6. 2 & 63 & 34 & 3 \\
\hline Southwest pine ${ }^{2}$ - & 7.8 & 79 & 16 & 5 \\
\hline All units.... & 29.1 & 56 & 28 & 16 \\
\hline
\end{tabular}

( Data in greater detail are given in table 15, Appendix.

2 Includes values for southeast pine unit.

Comparison of the acreage of idle and abandoned agricultural land with that of recently cleared cropland seems to indicate that the forest area of Louisiana is gradually increasing. Abandonment of farm lands is most prevalent in the "piney woods" of the north pine unit, which contain considerable tracts of relatively low fertility and serious soil erosion. Farm cropping is constantly shifting from such districts to the more fertile, noneroded lands on the lower terraces and into bottoms adjacent to streams. Farm use of the Delta bottom lands is, therefore, increasing somewhat. For the State as a whole, however, the forest area will probably remain at least as great as it now is, or increase slightly.

\section{Ownership}

In 1938, the ownership of the forest land was distributed as is indicated in table 4. In that year the Forest Service in cooperation with the State forester of Louisiana, made a canvass of the larger industrial and other private owners of forest land, not including farmers. The holdings of the 128 owners interviewed aggregated 4.4 million acres, of which 3.5 million was held by 59 industrial owners, chiefly lumber companies and pulp mills. The 69 other owners were investment companies, estates, and individuals. Of the total land covered by this inquiry, almost 4.2 million acres was held in 61 individual ownerships of 15,000 acres or more. A forest educational campaign concentrated on these few owners alone would potentially affect at least 25 percent of the forest land in the State.

\section{TABLE 4-Distribution of forest-land ownership, 1938}

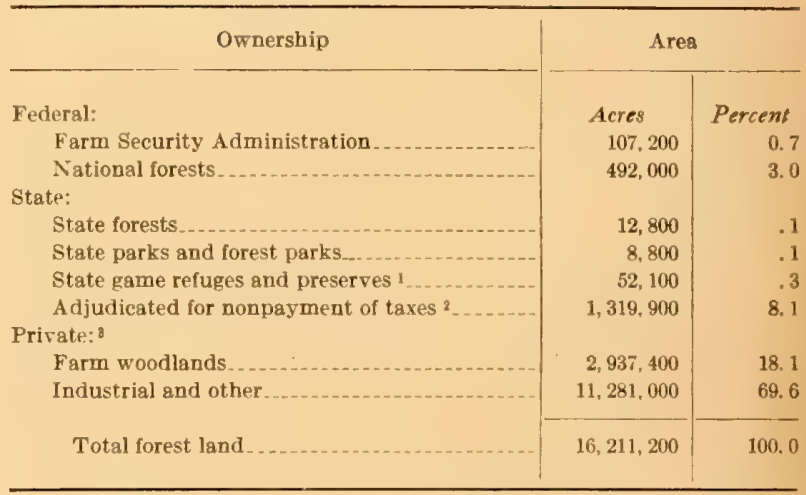

1 Net forest land. 2 Estimated.

3 From 1935 Census of Agriculture, less pstimated area adiudicated to State for nonpayment of taxes.

The preponderance of industrial and other nonfarm ownership of forest land is rather general throughout the State. The north pine unit is the only one where the economic importance of farm woodlands approaches that 
in other States of the lower South. It is estimated that the proportion of forest area in industrial and other nonfarm ownership, including public ownership and control, is as follows:

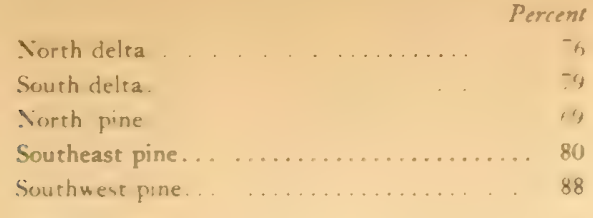

\section{Taxation}

An important factor adverse to productive forest management on some lands is the heavy weight of property taxes. Assessment and rate discrepancies and a general tendency to overassess low-priced forest lands give rise to serious inequities. The burdensome character of the taxes in Louisiana is evidenced by the extent of tax delinquency. According to the best available estimates, as of November 15, 1937, about 1.3 million acres of forest land had been adjudicated to the State for nonpayment of taxes; that is to say, the State has taken these lands over subject to redemption by the former owners or their heirs as long as title remains with the State. Currently there appears to be less delinquency than in 1937, but no detailed figures are available.

In the southwest pine region about 8 percent of the forest land has been adjudicated-the largest area of taxreverted forest land in any one unit and nearly a third of all such land within the State. In the southeast pine unit, where there is a higher proportion of area forested than in any other survey unit and also serious tax delinquency, about 8 percent of the forest area has likewise been adjudicated. The southeast unit and the south delta unit each account for nearly one-fourth of the total tax-forfeited forest land.

Efforts to relieve forestry of adverse effects of the property tax through tax adjustments began in 1910 with enactment of a law providing for partial exemption. This exemption was protected from subsequent repeal or amendment of the law through a contract set up between owner and State. This law has since been modified in several respects at different times, most recently in 1926. It now provides that an owner may apply for a contract with a life not exceeding 40 years, whereby he is bound to practice forestry on the designated lands and the
State is bound to grant special taxation. The asse value of the lands is fixed by the contract at their value ae time of application, as agreed upon by owner and poi jury (i. e., county commissioners), but the contract cannot be consummated unless this value averages between $\$ 3$ and $\$ 8$ per acre. During the life of the contract the lands can be taxed only upon this fixed assessed value. Also, the forest products grown under the contract are exempt from all taxation for 50 years from the contract date, except that a yield tax of 6 percent is collectible at the time of severance.

As of July 1, 1941, a total of 459,992 acres was under contract by 56 owners in 14 parishes. This is less than 9 percent of the total area eligible. The high point was attained 2 years earlier, when 563,762 acres of land was under contract with 70 owners. In 15 years, to the end of 1941 , only $\$ 12,343$ in yield taxes had been collected, indicating that only a little over $\$ 200,000$ worth of forest products had been removed from contract lands. Factors that may limit the application of this law include reluctance of a property owner to agree to a fixed use for a long period, or to become a party to a contract which later on may turn out unfavorably, and the difficulty of reaching agreement with the police juries regarding the value of lands offered for classification under the law.

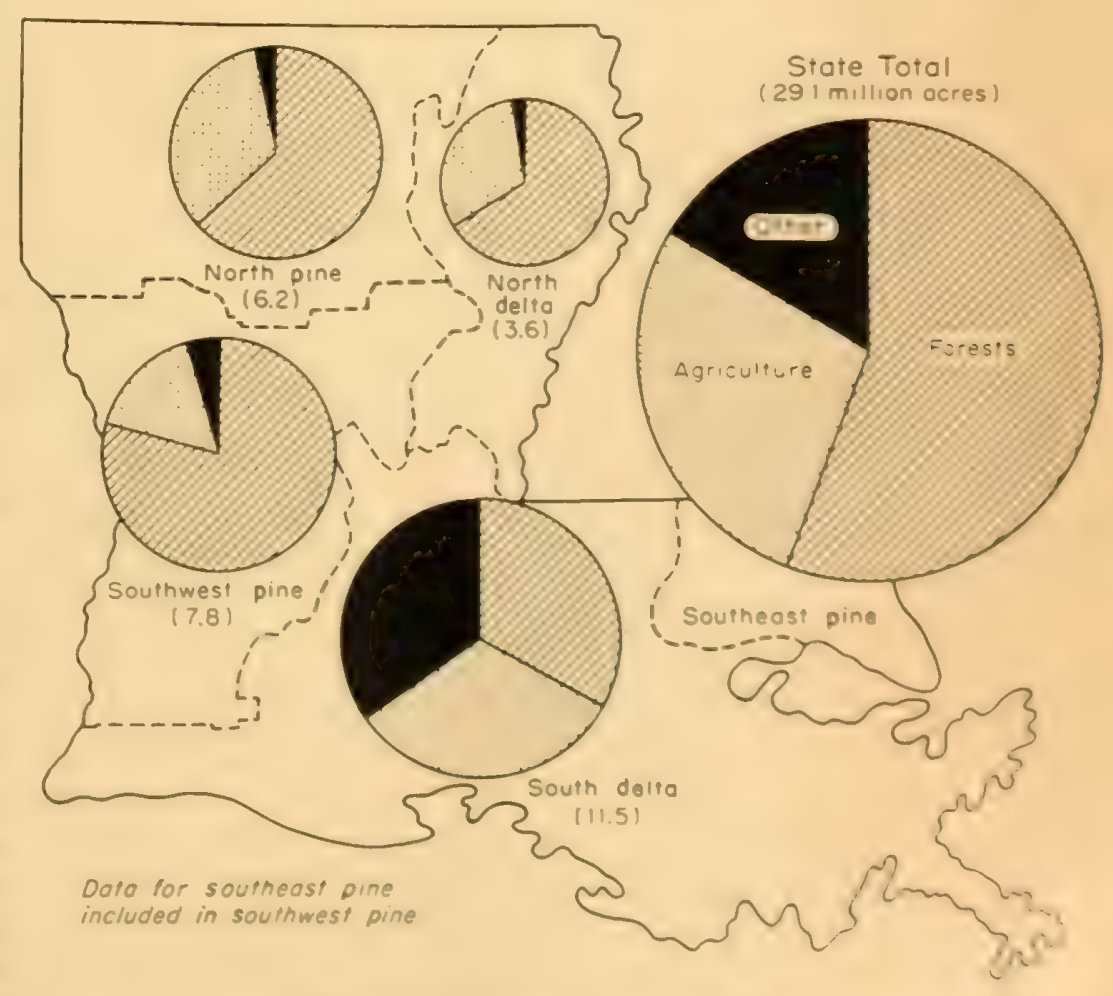

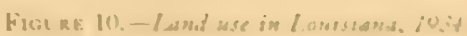




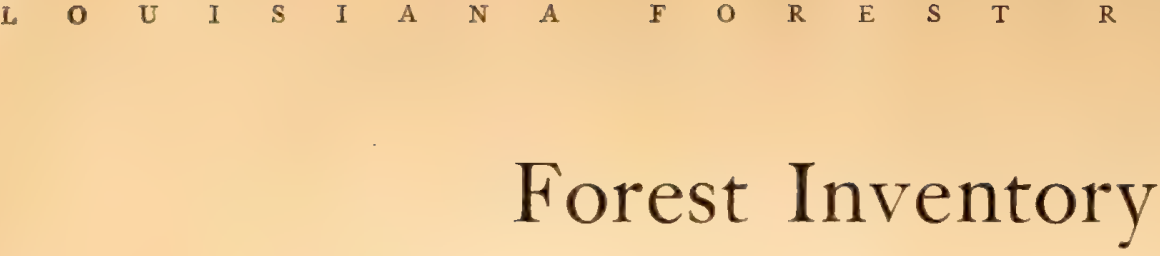

data), naval stores trees, and stumps available for naval stores production.

\section{Saw-Timber Volume}

The volume of saw timber in Louisiana totals 42.4 billion board feet. Of this total 36 percent is in pines and 64 percent in hardwoods and cypress (fig. 11). Loblolly pine makes up more than half the pine volume, shortleaf pine about one-fourth, and longleaf and slash pines practically all the remainder. Half the hardwood saw-timber volume is about equally divided among the red oaks, sweetgum (redgum), and tupelos (fig. 12). Although it is not commonly realized, two-fifths of the hardwood volume is in stands situated within the pine units. As is shown in table 5, virtually all the longleaf pine saw-timber volume occurs in the two south pine units; shortleaf and loblolly

were made in the survey of Louisiana are poles and piles

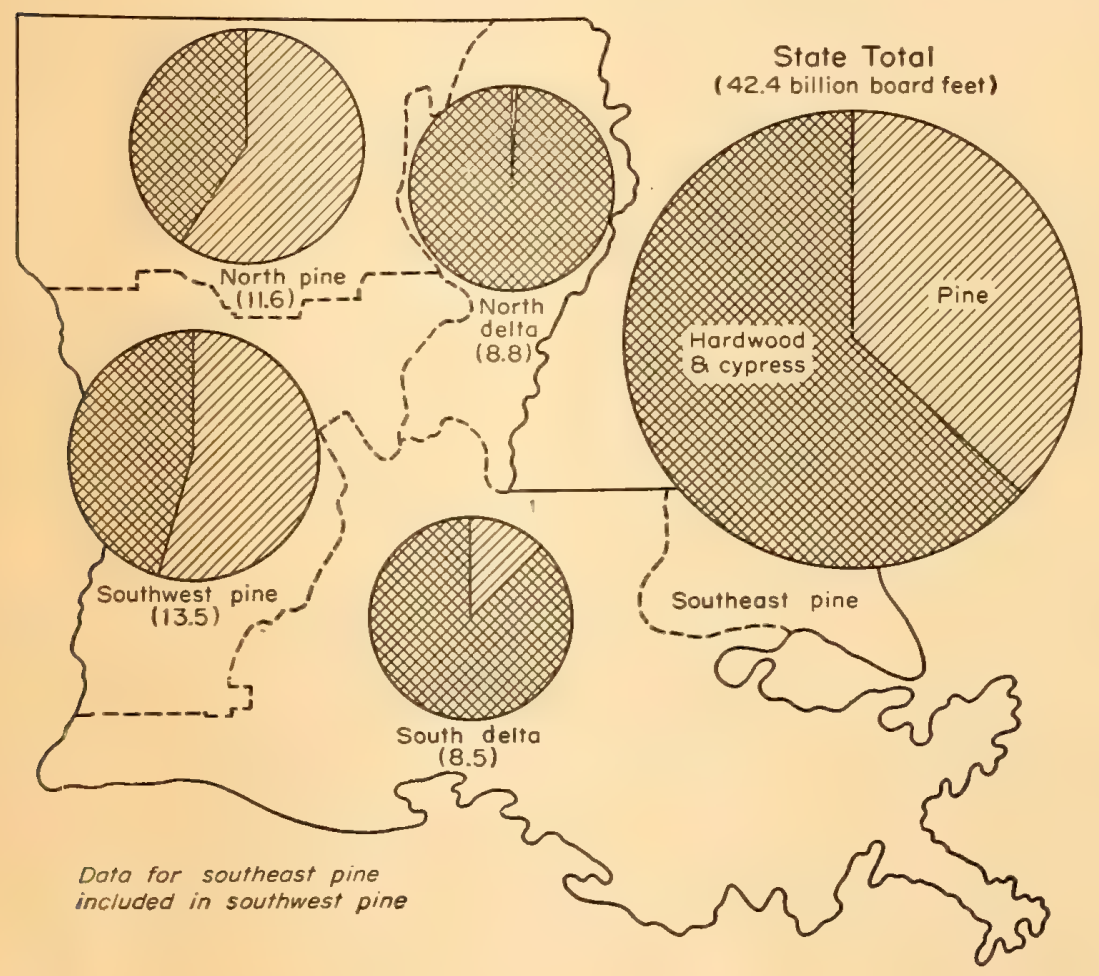

Figure 11.--Proportion of pine and hardwood (and cypress) in each survey unit. 
Figure 12.-Nel hardwood and cypress saw-simber volume by species group and survey unit, 1934-35. ("Gums" include water iupelo, black gum, and sweetgum.)

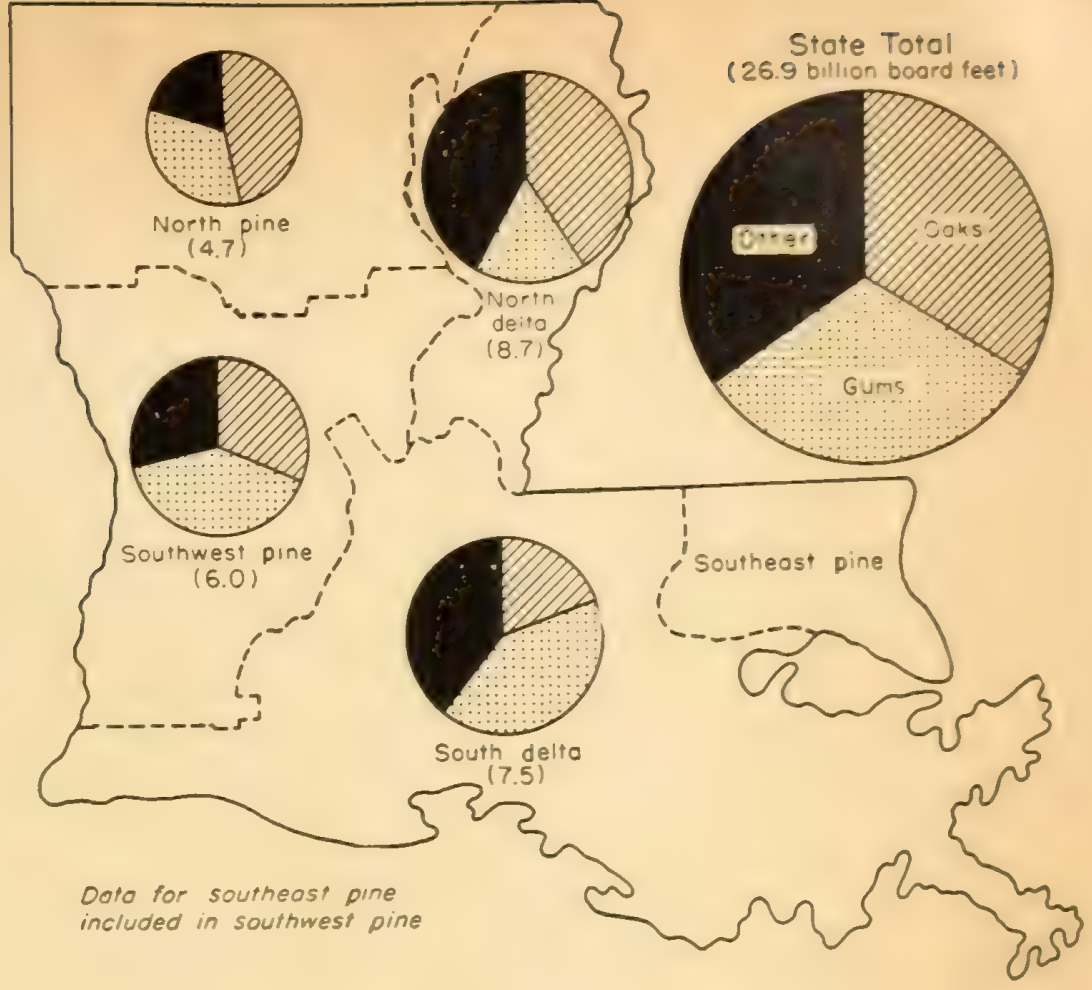

pines predominate in the north pine unit; the gums (chiefly water tupelo) form the greatest component in the south delta; and oak volume is greatest of the hardwoods in the north delta (fig. 12).

The distribution of the saw-timber volume by forest condition is indicated in table 6 and figure 13. Although old-growth uncut forests occupy only 8 percent of the forest area, they contain over 23 percent of the saw-timber volume. The 12 percent of the forest area classed as occupied by partly cut old growth supports 20 percent of the total saw-timber volume. Nearly three-fourths of

TABLE 5.-Distribution of net saw-timber volume by species group and survey unit, 1937-35

\begin{tabular}{|c|c|c|c|c|c|c|c|}
\hline \multirow[b]{2}{*}{ Survey unit } & \multirow[b]{2}{*}{$\begin{array}{c}\text { Volume, } \\
\text { all } \\
\text { species }\end{array}$} & \multicolumn{2}{|c|}{ l'ines } & \multicolumn{3}{|c|}{ Hard woxels } & \multirow[b]{2}{*}{ Cypress } \\
\hline & & $\begin{array}{l}\text { Long- } \\
\text { lear- } \\
\text { slash }\end{array}$ & Other & Oaks & $\begin{array}{c}\text { Tupo- } \\
\text { los, } \\
\text { sweet- } \\
\text { gum }\end{array}$ & Other & \\
\hline North delta............ & $\begin{array}{l}\text { Bullion } \\
\text { od.fe. } \\
8.8\end{array}$ & Pdt. & $\begin{array}{l}\text { Pct. } \\
\text { (ग) }\end{array}$ & $\begin{array}{r}\text { Pt. } \\
41\end{array}$ & ${ }_{17}$ & $\begin{array}{r}\text { Pt. } \\
40\end{array}$ & Pde \\
\hline South delta............ & 8.5 & 0 & 12 & 17 & 37 & 27 & \\
\hline North pine............. & 11.6 & 1 & 59 & 19 & 13 & 7 & 8 \\
\hline $\begin{array}{l}\text { Southwest and south- } \\
\text { east pine }\end{array}$ & 13.5 & 18 & 37 & 14 & 18 & 111 & 1 \\
\hline All units........ & $\$ 2.4$ & 6 & 30 & 22 & $20^{\prime}$ & 19 & 3 \\
\hline
\end{tabular}

1 Detailent data given in tahle 17 , Aprendix. 21 es $t$ than 0,5 percert,

- Includes data for southeast delta.
TABLE 6.-Net board-foot colume. lumber tally, classified according to species group, forest condition, and sureey unit. 1934-35 i

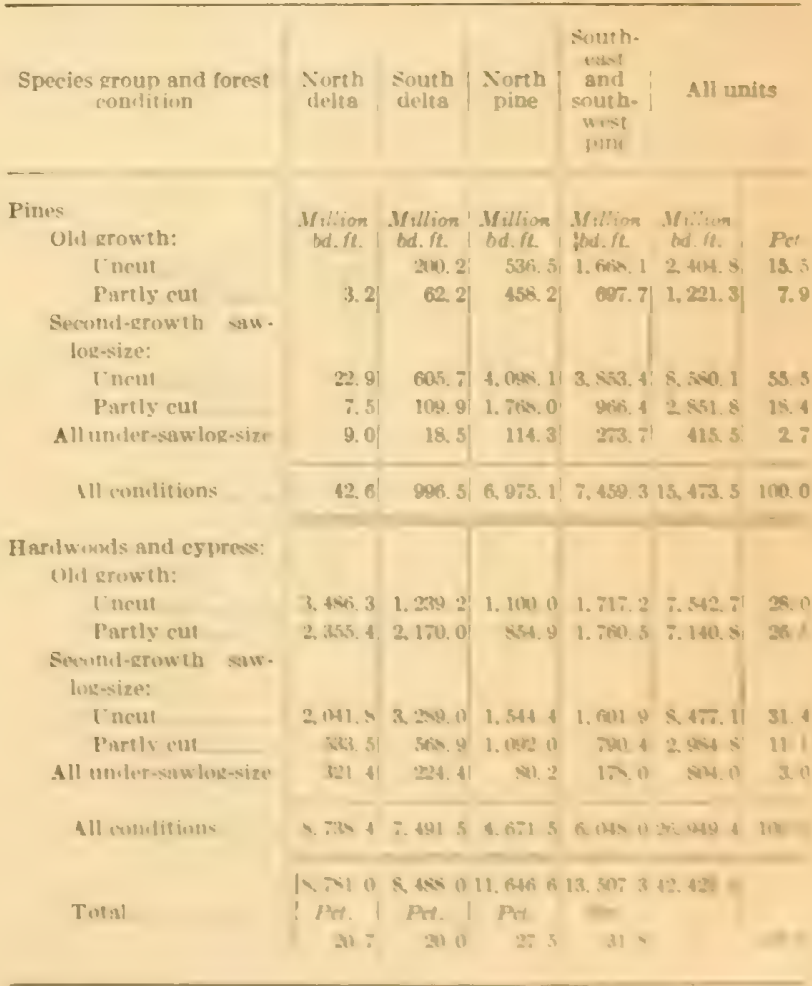

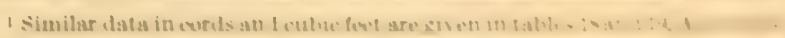




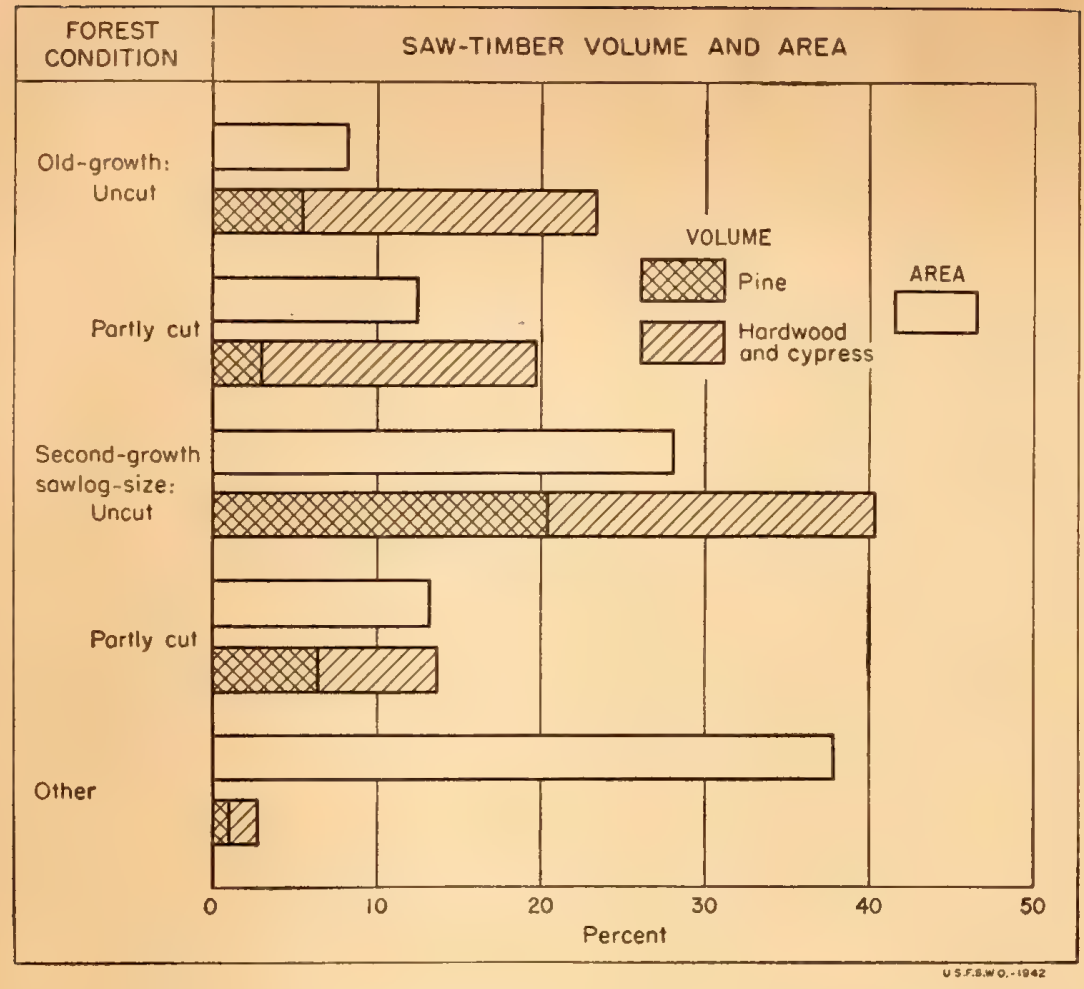

Figure 13.-Relation of saw-timber volume to forest area in different forest-condition classes 1934-35.

the pine volume, however, and more than two-fifths of the hardwood volume occur in uncut or partly cut secondgrowth stands of sawlog size.

Not all the 42.4 billion board feet of saw timber is of sufficient size and quality or in sufficient concentration for practical logging by operators of sawmills and other forest-industry plants under prevailing market conditions and requirements. Accordingly, the forest areas were classified on the basis of timber quality and volume per acre.

In the survey units of the Mississippi River Delta, the forest areas with 1,000 board feet or more per acre of
FIGURE 14.--Relation of forest area to sawtimber volume in quality classes $A$ and $B$ in the two delia units, 1934-35.

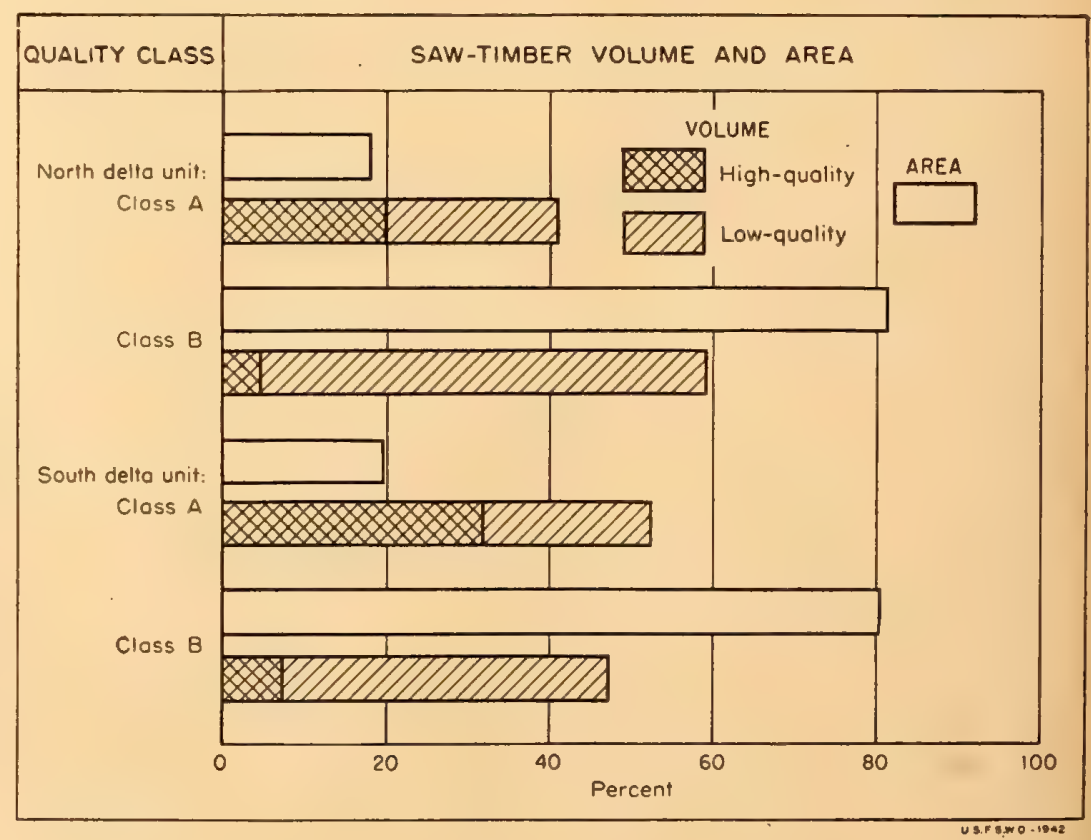




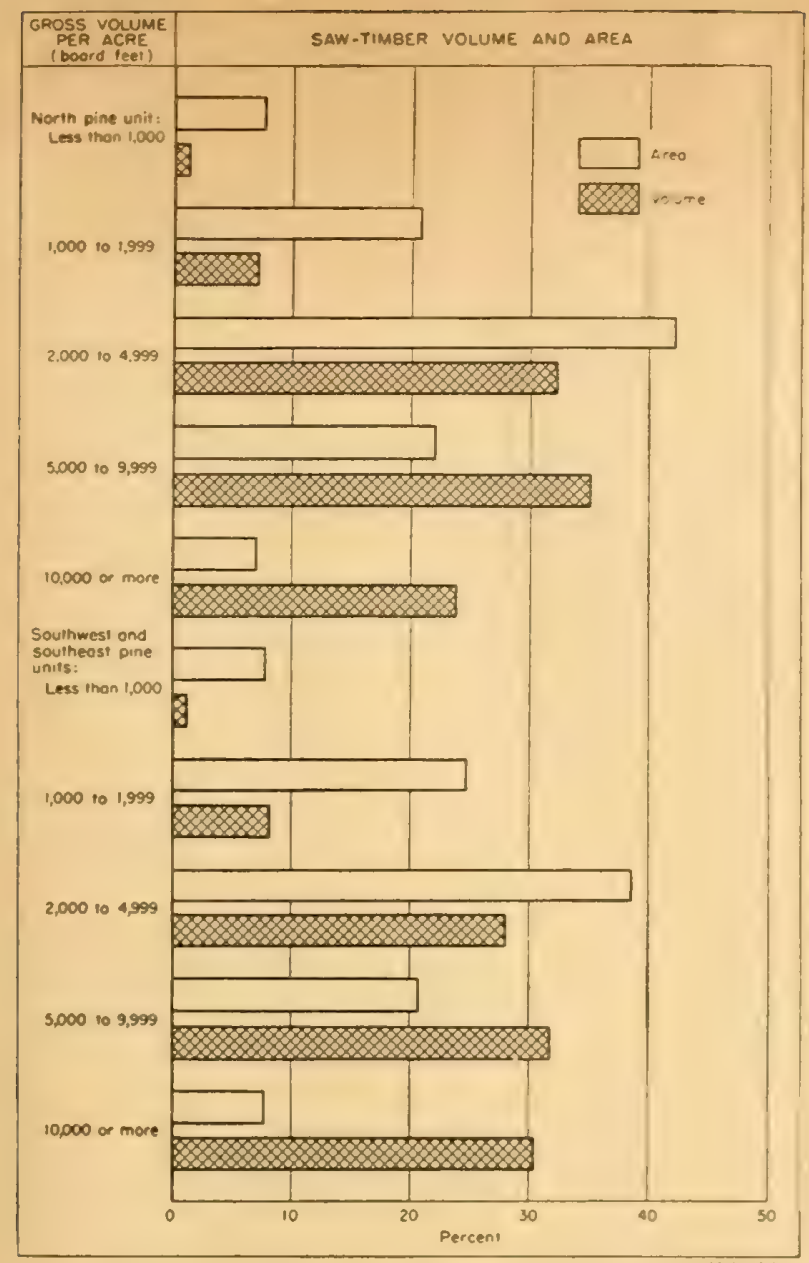

Ficere 15.-Area and solume comparison for the upland satrlog-size forest conditions in the pine uniss, according 80 gross valume of saw simber per acre, $1934-35$.

higher-quality saw timber (i.e., timber suitable for the manufacture of industrial lumber, veneer, and cooperage stock) were called class $\mathrm{A}$ areas; all others were called class $B$. In the north delta unit only 18 percent of the forest land is in class $\mathrm{A}$; but this area supports 41 percent of the saw timber, of which about half is of high quality. On the class $B$ forest area in this unit, less than 8 percent of the saw-timber volume is of high quality. In the south delta unit 20 percent of the forest land is in class $\mathrm{A}$, and three-fifths of the saw timber on this land and about onesixth of that on the class B forest area is of high quality (fig. 14).

A break-down of the saw-timber forest area in the rolling uplands of the pine survey units, on the basis of volume of timber per acre (fig. 15), indicates that the two south pine units have a slightly greater proportion of their sawtimber volume on areas supporting 5,000 board leet or more per acre than has the north pine unit. In the nurth pine unit, stands of 2,000 board feet or more per acre occupy 72 percent of the forest area and include $92 \mathrm{pe}$ of the saw-timber volume. Areas that support $5,(x)(0)$ brard feet or more per acre make up only 30 percent of the total forest area but contain 59 percent of the saw-timber volume. In the south pine units, stands of 2,000 board

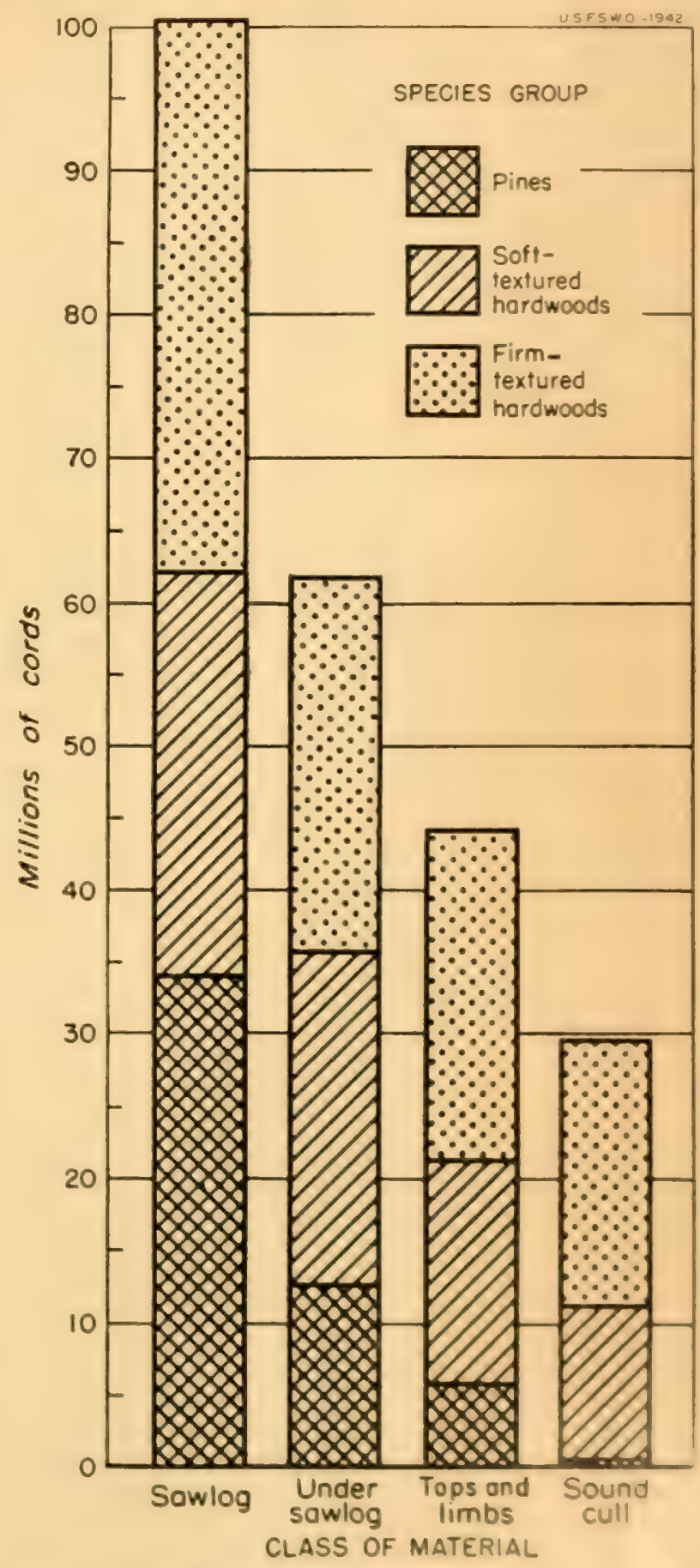

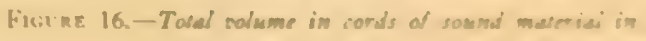
iperies group, size, and ibess of maservai, 
feet or more per acre occupy 69 percent of the area and include 91 percent of the saw-timber volume. Here, likewise, timberlands that support 5,000 board feet or more per acre make up only 31 percent of the area, but contain 63 percent of the saw-timber volume.

\section{Total Volume in Cords}

The total volume of sound material, including bark, and the saw-timber material previously described, is 237 million cords. This total is made up of 101 million cords in saw-timber material, 62 million cords in under-sawlogsize trees, about 44 million cords in the tops and limbs of saw-timber trees, and about 30 million cords in cull trees (fig. 16). More than 77 percent of it is in hardwoods and cypress, less than 23 percent in pines. Nearly 98 percent of the sound volume in cull trees, and more than 86 percent of the volume in tops and limbs of saw-timber trees, is in hardwoods and cypress material. The distribution of cordwood volume among the survey units is shown in table 18 in the Appendix.

Requirements for pulpwood, fuel wood, fence posts, and similiar uses can largely be met with material of small size or of quality inferior to that required for lumber, veneer, etc. It must be kept in mind, however, that much of the volume in under-sawlog-size trees should be reserved as growing stock for future saw timber, and that tops and limbs of saw-timber trees will not become available until the trees are cut. A little more than 42 percent of the 183 million cords of hardwoods and cypress is in soft-textured species, generally considered more suitable for paper manufacture.

Volume of growing stock per acre by species groups is shown for the various forest type groups in figure 17. The longleaf-slash pine type group, which includes nearly all the stands that have been clear cut, has the smallest average growing-stock volume per acre, 3 cords; the shortleaf-loblolly pine-hardwood type group has the largest, $12 \frac{3}{4}$ cords. Of the latter volume an average of $10 \frac{1}{2}$ cords per acre is in the species now considered suitable for the manufacture of pulp, whereas the total for the hardwood type group includes only about 5 cords of soft-textured species per acre. It should be borne in mind however, that certain species not considered suitable for manufacture pulp at present may eventually become acceptable for that use because of new technical developments; the industry already is using firm-textured hardwoods long considered unpulpable.

Naturally, volume of growing stock per acre varies according to age of stand and degree of stocking. In the uncut second-growth sawlog-size timber it averages in the neighborhood of 15 cords per acre, all Louisiana survey

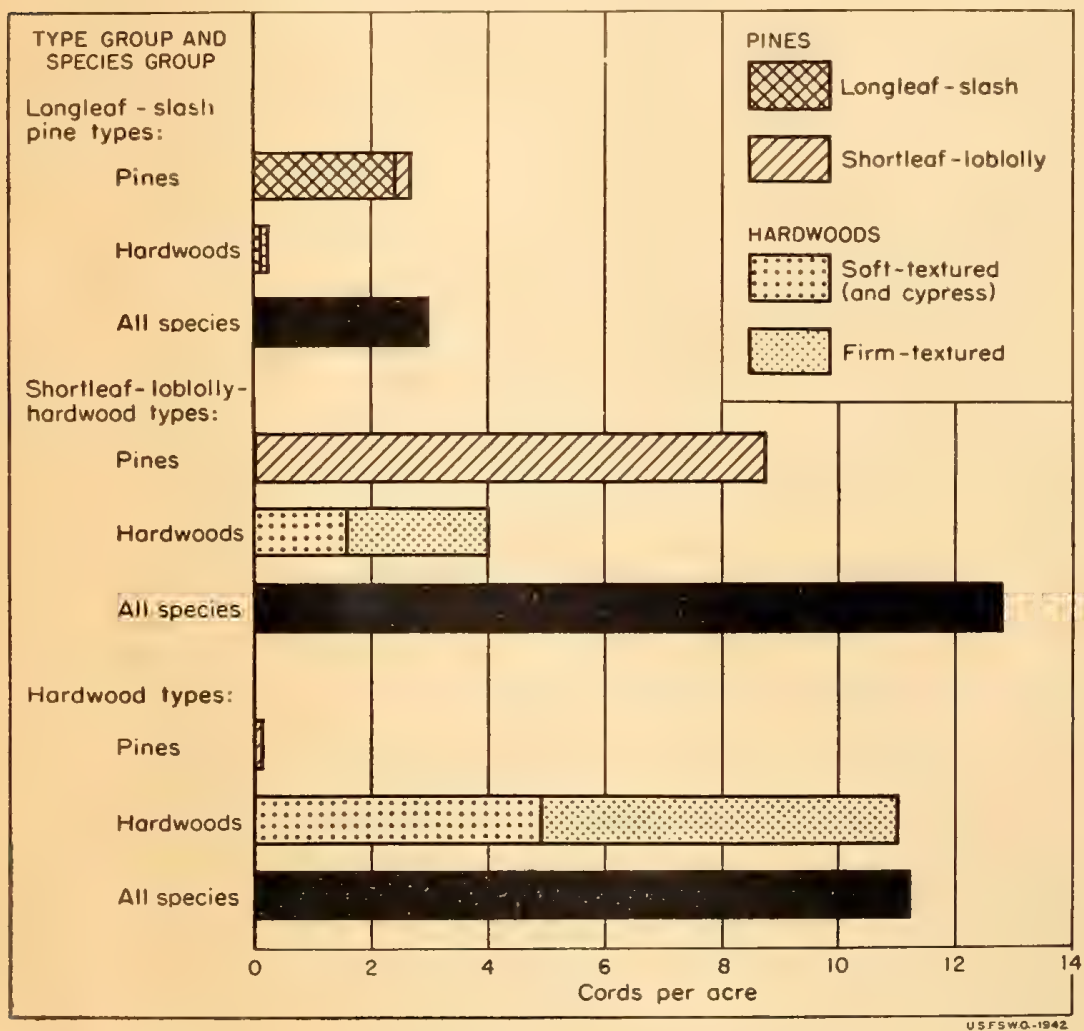

FICURE 17.-Growing-stock volume in cords per acre by species groups within major type groups. $1934-35$. 
Figure 18. - Kind of makerial composing net cubic-foot volume in each suroey unit, $1934-35$.

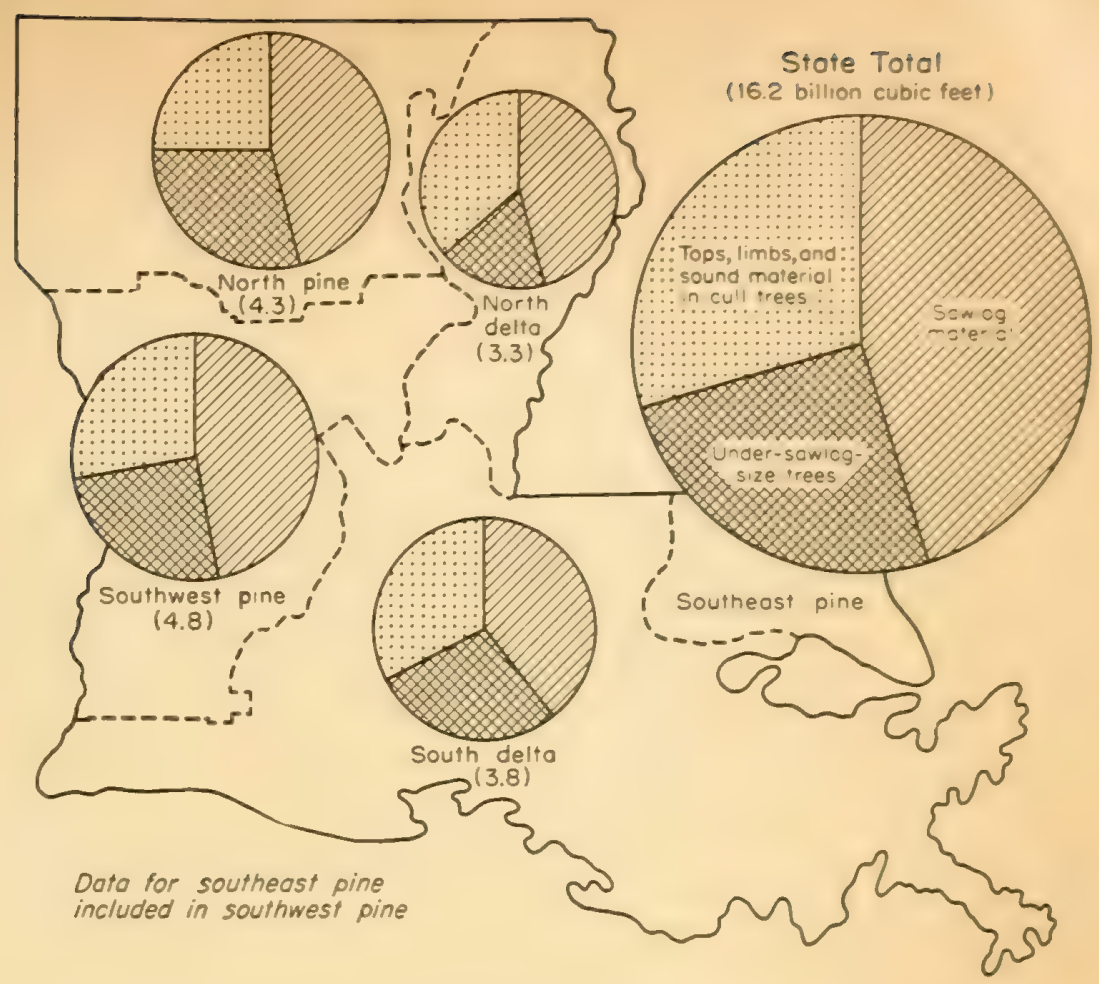

units included; and in timber under sawlog size, from 3 to 6 cords per acre.

\section{Cubic-Foot Volume}

The estimated total of 16.2 billion cubic feet of solid wood includes all sound volume, in trees 5.0 inches d.b.h. and larger, in tops and limbs of saw-timber trees, and the usable parts of culls (fig. 18). Approximately three-fourths of this total is hardwoods and cypress, the remainder pine.

It is of interest to sawmill operators that nearly twothirds of the pine volume is in sawlog material, about a fourth in trees under sawlog size, and only 1 percent is in cull trees (table 7). Of the hardwood and cypress volume less than two-fifths is in sawlog material, one-fourth is in trees under sawlog size, and the cull trees, tops, and limbs combined are about equal in volume to the sawlog material.

\section{Special Forest Resources}

Included in the timber volumes already presented are trees suitable for poles and piles. Other special forest resources are turpentine trees for gum naval stores, seasoned stumps for wood naval stores, and Spanish moss.

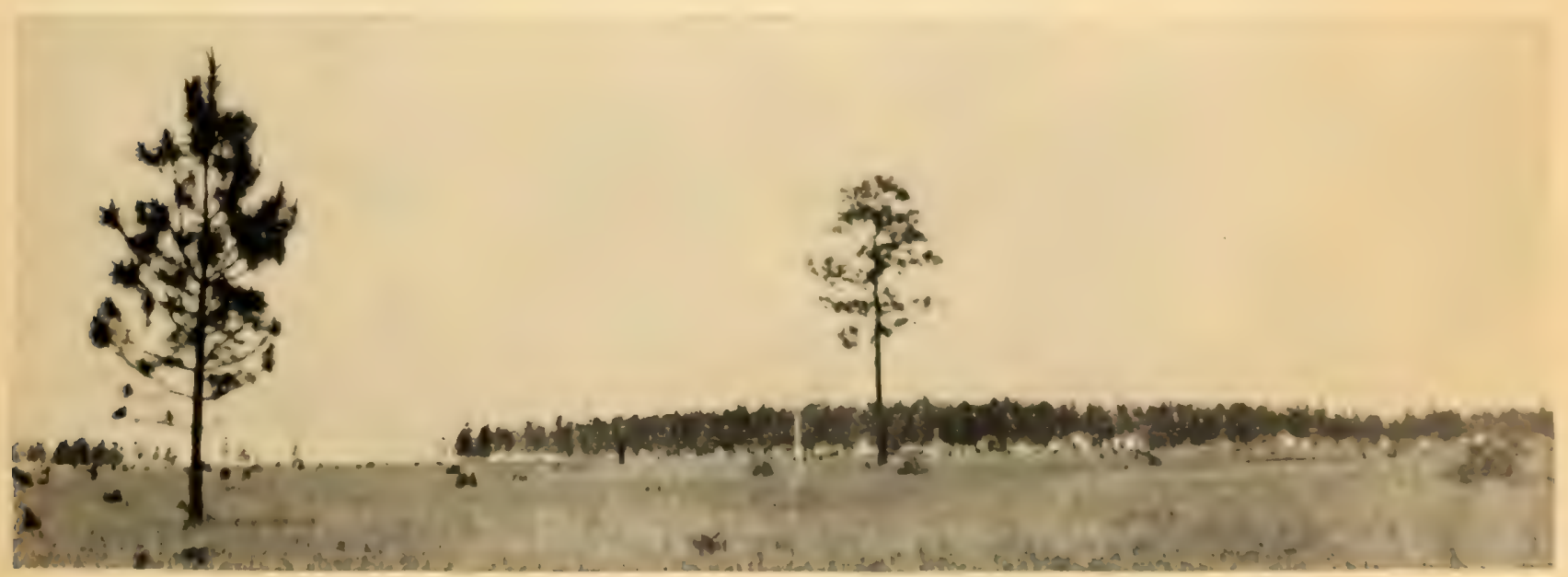

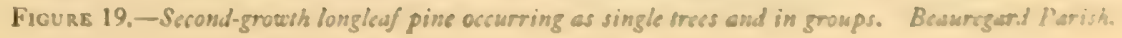


TABLE 7.-Cubic-foot volume (inside bark) of sound wood, by quality class, $1934-35^{1}$

\begin{tabular}{|c|c|c|c|c|c|}
\hline \multirow{2}{*}{ Species group and survey unit } & \multirow{2}{*}{$\begin{array}{c}\text { Total } \\
\text { volume }\end{array}$} & \multicolumn{2}{|c|}{$\begin{array}{c}\text { Sound sawlog } \\
\text { trees }\end{array}$} & \multirow{2}{*}{$\begin{array}{l}\text { Other } \\
\text { sound } \\
\text { trees }\end{array}$} & \multirow{2}{*}{$\begin{array}{l}\text { Cull } \\
\text { trees }\end{array}$} \\
\hline & & $\begin{array}{c}\text { Sawlog } \\
\text { ma- } \\
\text { terial }\end{array}$ & $\begin{array}{l}\text { Top } \\
\text { wood } \\
\text { and } \\
\text { limbs }\end{array}$ & & \\
\hline Pine: & $\begin{array}{l}\text { Million } \\
\text { cubic feet }\end{array}$ & Percent & Percent & Percent & Percent \\
\hline North delta................. & 14. 1 & 54.3 & 8.4 & 35.2 & 2.1 \\
\hline South delta............ & 237.11 & 71.9 & 13. 2 & 14. 2 & .7 \\
\hline North pine.......... & $1,900.7$ & 63.6 & 10.8 & 24.8 & .8 \\
\hline Southwest pine $2 \ldots$ & 1.933 .9 & 65.1 & 11.5 & 21.5 & 1. 9 \\
\hline All pine .......... & $4,085.8$ & 64.8 & 11.3 & 22.6 & 1.3 \\
\hline \multicolumn{6}{|l|}{ Hardwood and cypress: } \\
\hline North delts . . ...... & 3, 296. 2 & 45.9 & 26.3 & 17.0 & 10.8 \\
\hline South delta........ & $3,606,3$ & 36.8 & 18.6 & 29.0 & 15. 6 \\
\hline North pine & $2,396.2$ & 32.2 & 16.4 & 32.4 & 19. 0 \\
\hline Southwest pine? & $2,809.6$ & 35.7 & 18. 1 & 27.0 & 19. 2 \\
\hline All hardwood. & $12,108.3$ & 38.1 & 20.1 & 26.0 & 15.8 \\
\hline
\end{tabular}

1 Detailed figures are given in table 19, Appendix.

2 Includes data for southeast pine unit.

\section{Poles and Piles}

Survey findings indicate that about 1 out of every 6 pine trees 7 to 19 inches d.b.h., or 29 million in all, meets the requirements for poles (based on specifications of the American Standards Association) or for piles. Although the proportion of such trees is slightly greater in the north unit than in either of the south units, availability of pole material is greater in the southern stands, few of which contain sufficient volume to be logged for lumber.

It is of interest to the wood-preserving industry that nearly two-thirds of the trees suitable for poles or piles are less than 11 inches d.b.h. outside bark and most of these will furnish poles no longer than 25 feet (fig. 20, see also table 21, Appendix).

\section{Naval Stores Resources}

In the south pine units there were in 1935 about 55 million round longleaf and slash pine trees 1.0 inch d.b.h. or larger - of which, however, less than 10 million were as large as 9.0 inches d.b.h. (table 8). The second-growth longleaf pines large enough for turpentining usually occur as scattered trees or small groups (fig. 19). Moreover, there is a strong demand for such material for posts, poles, piles, and lumber. These facts make it seem improbable that the gum naval stores resource will regain its past importance in Louisiana.

In 1935 there were in the two south pine units about $7 \frac{1}{2}$ million tons of longleaf pine stumps removable by blasting and available for naval stores production under

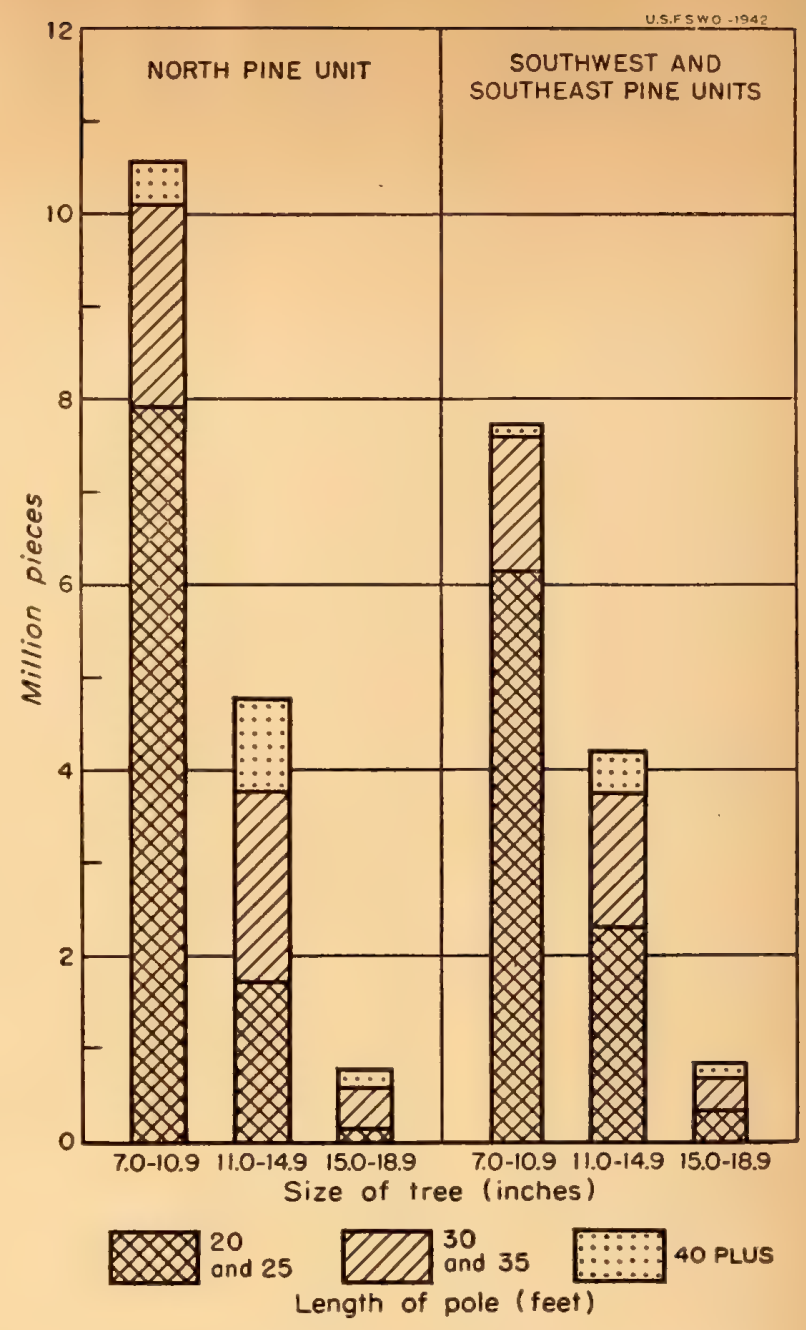

FIGURE 20,-Number of pine poles and piles in the pine survey units, classified according to length and tree diameter, 1934-35.

present operating standards (see table 20, Appendix). These stumps occurred in all forest conditions, but 58 percent were on clear-cut areas that contained 14 or more stumps per acre.

TABLE 8.-Turpentine pines, by condition of tree and of area, $1934-35$

\begin{tabular}{|c|c|c|c|c|}
\hline \multirow[b]{2}{*}{ Area condition } & \multicolumn{2}{|c|}{ Round trees } & \multirow{2}{*}{$\begin{array}{c}\text { Working, } \\
\text { resting, } \\
\text { and } \\
\text { worked } \\
\text { out }\end{array}$} & \multirow{2}{*}{ All trees } \\
\hline & $\begin{array}{l}1.0 \text { to } 8.9 \\
\text { inches } \\
\text { d.b.h. }\end{array}$ & $\begin{array}{l}9.0+ \\
\text { inches } \\
\text { d.b.h. }\end{array}$ & & \\
\hline & 1,000 trees: & 1,000 trees & 1,000 trees & 1,000 trees \\
\hline Round-timber & 45,256 & 9,371 & 120 & 54,747 \\
\hline Working........... & 119 & 123 & 391 & 633 \\
\hline Worked-out and resting & 1,038 & 360 & 1,499 & 2,897 \\
\hline Total & 46,413 & 9,854 & 2,010 & 58,277 \\
\hline
\end{tabular}




\section{Forest Industries}

\section{The Lumber Industry}

$\mathrm{L}$ OUISIANA once had some of the largest lumbering operations east of the Great Plains, and still leads the South in number of large sawmills. In 1937 the Forest Survey recorded 557 sawmills in the State (table 9). Slightly more than a tenth of these had capacities of $40 \mathrm{M}$ board feet or more per 10-hour day and were classed as large mills. Another tenth had daily capacities of 20 to $39 \mathrm{M}$ board feet. The remaining four-fifths (1 to $19 \mathrm{M}$ board feet) were mostly portables.

In 1937, southwest Louisiana contained 12 sawmills with 10-hour capacities of $80 \mathrm{M}$ board feet or more, comprising most of the mills of this size in the State. Such mills sawing longleaf pine were located at Zimmerman, Alco, Longleaf, and Leesville; others sawing chiefly hard-

TABLE 9. -Number of sawmills in each suroey unit, by capacity per 10-hour day, and kind of timber cut, 1937 and 1940

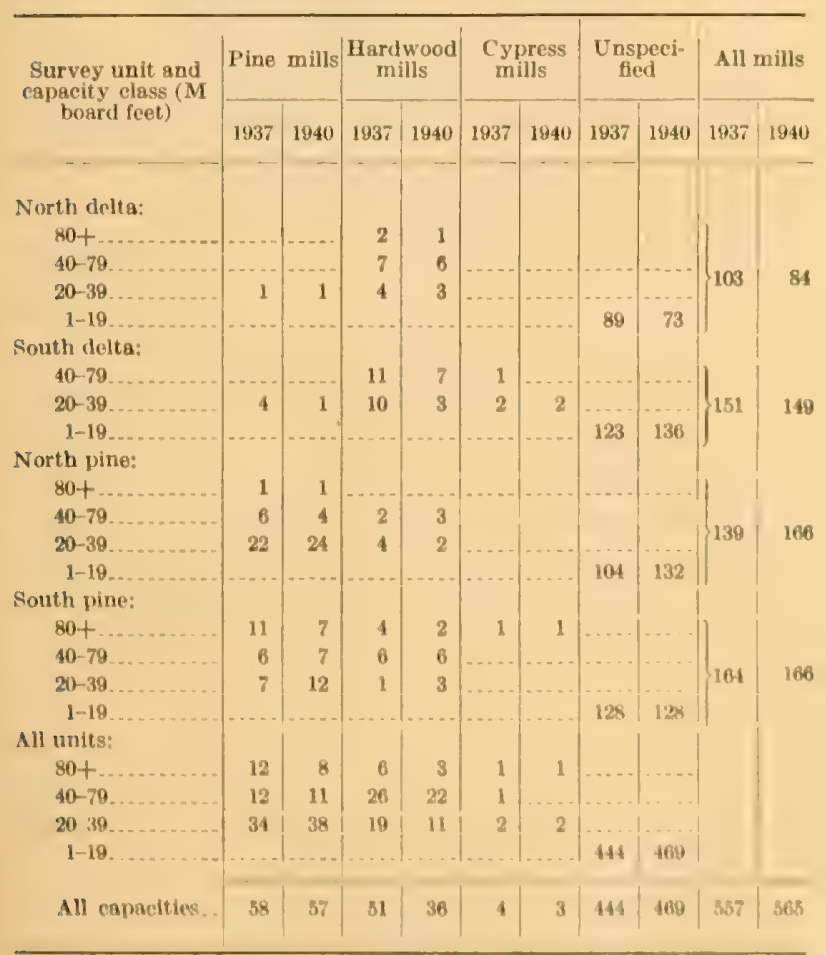

wood, at Oakdale and Trout. The south delta unit contained 28 of the medium and large sawmills of 20 to $79 \mathrm{M}$ board feet capacity, and the north pine unit, 34; thus, these two units had about two-thirds of the mills in these size groups in the State. Small mills were most numerous in the south delta and south pine units. This distribution of mills is shown in figure 21 .

Although the large mills numbered only 10 percent of the total in 1937, they accounted for 68 percent of the lumber produced. Medium-sized mills, of which there were slightly fewer, sawed 21 percent of the lumber; and small mills, which amount to 80 percent of the total number of establishments, sawed only 11 percent (fig. 22).

Within the next two decades, a number of the mills sawing as much as $80 \mathrm{M}$ board feet per day will probably cease operating, because of the inadequate supplies of available timber near them. On the other hand, the large areas of productive forest lands with maturing secondgrowth stands should enable several companies operating large sawmills to continue indefinitely. In 1940 the number of mills in the State increased to 565 , but the increase was entirely in the class of mills with a daily capacity of less than $20 \mathrm{M}$ board feet. The number of medium sized mills fell off from 55 to 51 and the large mills from 58 to 45 (table 9).

Small mills probably will continue to be numerous and locally important, because of their adaptability to small logging operations and their ability to supply rural areas and small towns with lumber at low cost. At this time, however, there is little reason to believe that small mills will manufacture as large a part of the State's lumber production as has happened in some parts of the Southeast and in the piedmont region. The increase in number of small mills between 1937 and 1940 increased the proxluction of the class 64 percent; but even though the two larger mill classes lost 11 mills, they still accounted for $8:$ percent of the lumber production of the State.

A few decades ago, lumber manufacturers usually | chased timber rights to extensive tracts of land supperting large volumes per acre, or bought the land ouiright. I ging was done with skidders or with animals, and: 


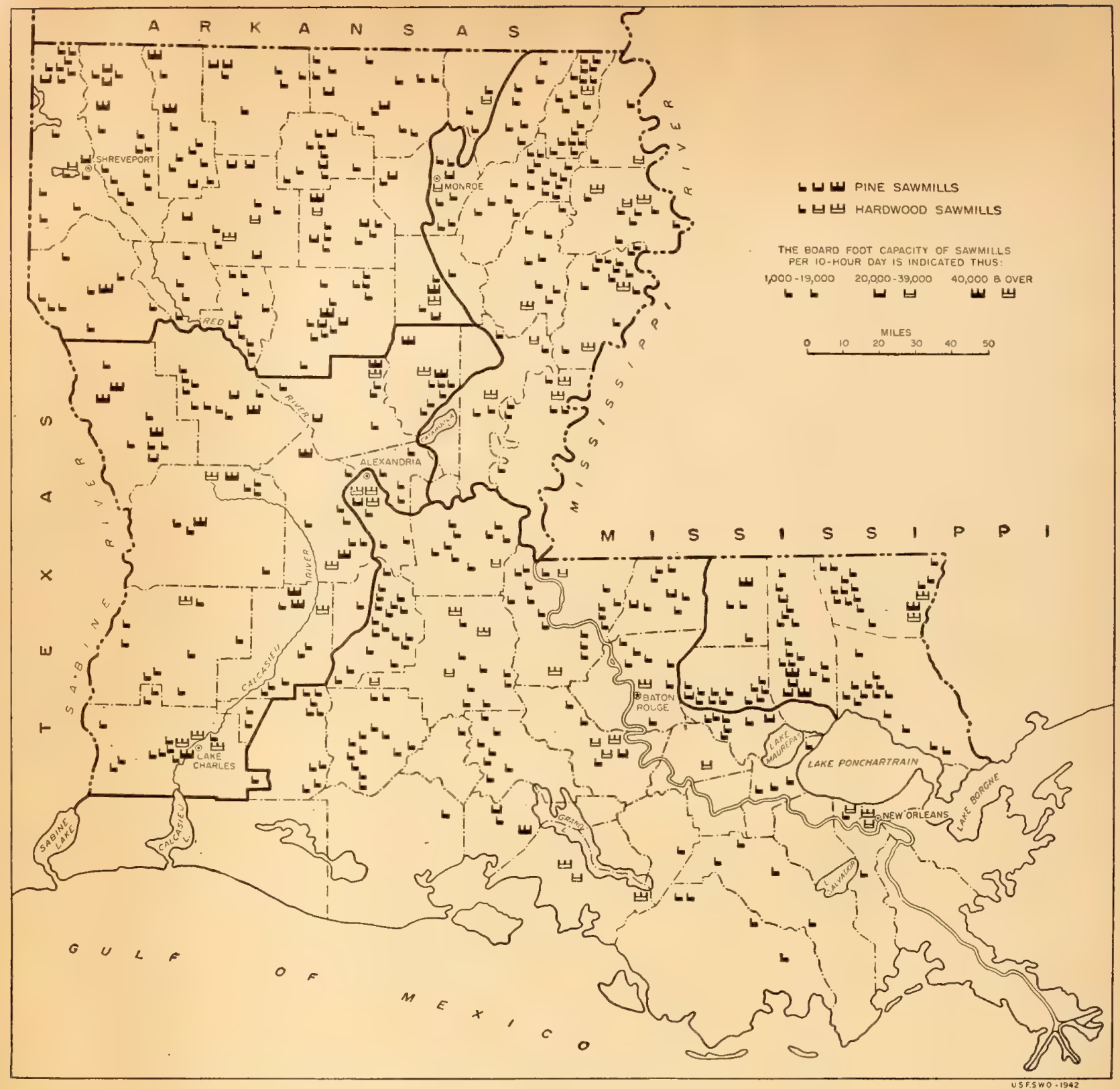

Figure 21.-Distribution of sawmills in Louisiana, 1937.

transported the logs to the mill. As a result of the cutting out of the large tracts of virgin timber, the construction of good highways, and improvements in motorized equipment, truck transportation has become common and is rapidly increasing. The logging truck has been an important factor in improved forest-management practices, because it makes frequent light cuttings and the utilization of scattered timber feasible. Furthermore, the advent of the truck made more feasible the practice of buying logs delivered to the mill. Some lumber manufacturers obtain all their logs by purchase on the open market; a greater number supplement their own timber supplies with logs purchased form logging contractors or from timber owners who do their own logging. The practice of buying logs at the mill is likely to become more common.

\section{The Nonlumber Forest Industries}

Not only sawmills but also other forest industrial plants, such as stave and heading mills, veneer plants, woodpreserving plants, and pulp mills, form an important part of the industrial organization in Louisiana (fig. 23). In 
addition are the gum and wood naval stores industries and a well-established if minor business in the curing of Spanish moss.

\section{Miscellaneous Wood Products}

In 1937 the State contained at least 88 nonlumber forest-industry plants (table 10), ranging in size from large pulp mills using several hundred cords of wood per day to small neighborhood shingle mills requiring only a few thousand board feet of timber per year. More than a third of these plants manufactured tight and slack cooperage stock, principally from hardwood timber. Most of them were in the Mississippi River Delta, where hardwood timber of suitable quality for cooperage is most abundant. Veneer mills, 15 in all, were next in number. There were also 12 treating plants, 7 small-dimension mills, and several miscellaneous plants, including 8 naval stores establishments.

In general, the manufacture of veneer, slack and tight cooperage stock, poles and piles, export stock, and specialties-such as blanks for baseball bats and other other athletic goods, shuttle blocks, and plugs for paper rollsrequires a large proportion of high-grade logs. Such industries, with the possible exception of those dealing in export logs or in certain classes of veneer, ordinarily draw on the high-grade material in second-growth or cutover stands. They can do this mainly because they can use timber of smaller average size or slightly lower average quality than that required by the lumber and veneer industries. Some of them, notably those making slack cooperage material and package veneer, regularly use species that are not utilized closely, if at all, by the sawmills. Some industries, particularly those producing tight cooperage and specialties, can use short bolts and billets, which require only the simplest logging equipment; thus it is practicable for them to utilize short, clear lengths between crooks unfit for lumber, and to log scattered individual trees. The shingle, pulp, and tie industries, because they do not require high-grade raw material, can operate still more effectively on the kind of timber most abundant in residual and second-growth stands.

TABLE 10.-Number of primary nonlumber wood-using plants, by survey unit, 1937

\begin{tabular}{|c|c|c|c|c|c|}
\hline Wood-using plant & $\begin{array}{l}\text { North } \\
\text { dolta }\end{array}$ & $\begin{array}{l}\text { South } \\
\text { delta }\end{array}$ & $\begin{array}{l}\text { North } \\
\text { pine }\end{array}$ & $\begin{array}{l}\text { South } \\
\text { pine }\end{array}$ & All units \\
\hline Treating ........... & ........ & 2 & 51 & 5 & 12 \\
\hline Veneer .............. & 2 & 5 & 2 & 6 & 15 \\
\hline Stave and heading... & 17 & 8 & 5 & 3 & 33 \\
\hline Pulp................... & 1 & $\ldots$ & 4 & 2 & 7 \\
\hline Small dimension.... & 2 & 1 & 1 & 3 & 7 \\
\hline Miscellaneous...... & 1 & 5 & 1 & 7 & 14 \\
\hline Total... & 23 & 21 & $18^{1}$ & 26 & 8n \\
\hline
\end{tabular}

\section{Pulp Mills}

The six sulfate pulp mills, situated at Bastrop (2), West Monroe, Hodge, Elizabeth, and Bogalusa, in 1937 placed the State first in the South in pulp production. Their annual capacity in operation was nearly 600,000 tons of pulp, which would require about 900,000 cords of pulpwood. These mills were then operating at considerably less than capacity, yet the production of pulp ranked second in value to that of lumber among the forest industries. Since then a new mill, the largest in the South and one of the largest in the world, has been constructed at Springhill, in Webster Parish. With this mill in operation, total consumption of pulpwood in 1940 was 838,000 cords.
Figure 22.-Distribution of sawmills and lumber production according to millcapacily class, 1937.

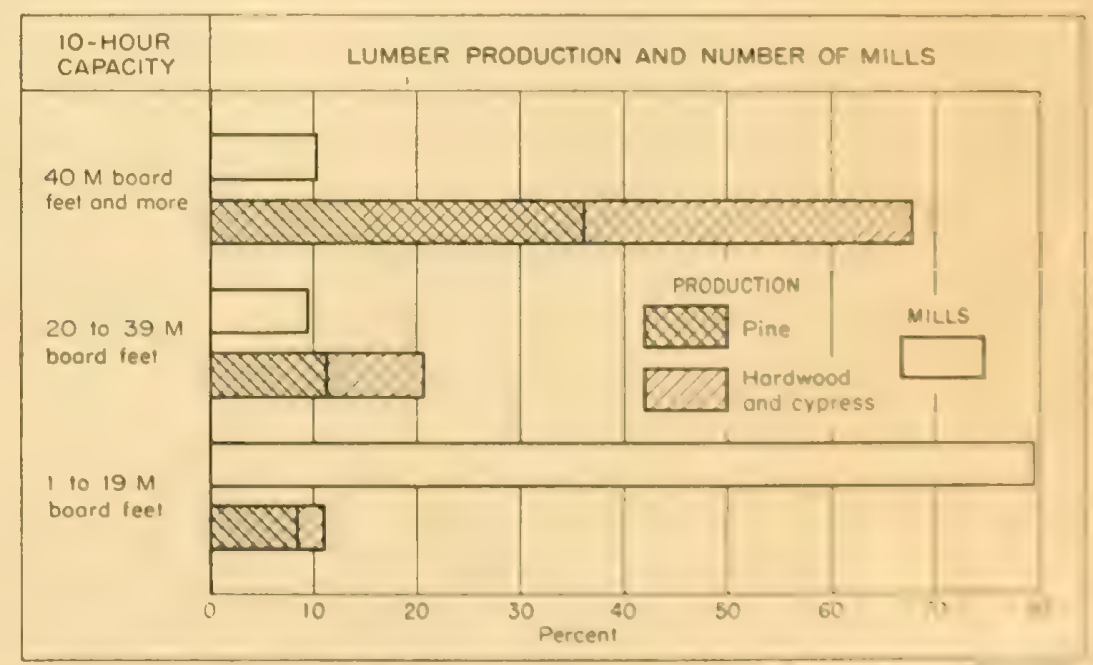


All the pulp-mill companies own some forest land, but outside contractors furnish a large part of the pulpwood. The wood is ordinarily assembled at rail side or delivered to the mill by truck. Because pulp mills can use small timber, they create a market for the smaller trees in overcrowded stands and for malformed or defective trees unfit for lumber.

The pulp industry has become an important factor in the economic life of Louisiana. Its leaders can add a great deal to the economic significance of forestry in the State if they continue to put into effect a far-sighted policy of forest management, not only on their own lands but also on the lands of those from whom they purchase wood. The large acreages owned by the pulp companies can serve well as demonstration forests, and if well managed will provide encouraging examples for the many thousands of woodland owners-particularly for those in the north pine unit, where pulpwood cutting is mainly concentrated and where small holdings are more prevalent than in other parts of the State.

The production of rosin, turpentine, and pine oils by wood distillation came into prominence in Louisiana after cutting of the old-growth longleaf pine left large areas of richly stocked and easily accessible stump land. In 1937 there were 4 wood-distillation plants in the State, of which 3 were in operation. These consumed about 121,000 tons of pine distillation wood (including a small amount from Mississippi), of which about four-fifths was stump wood and the remainder top wood. During that year these 3 plants extracted more than 7 times as much turpentine as was produced in the State from gum and provided nearly 211,000 man-days of employment-the equivalent of 200 days' work for about 1,055 people.

Since very little old-growth longleaf pine remains, and since stumps from second-growth stands are not at present acceptable to the industry, hardly any additions to the present supply of distillation wood can be expected. The wood naval stores industry, therefore, is operating largely on a "mining" basis; nevertheless, because the supply of available stumps is very large, there is room for expansion (table 21, Appendix). Indeed, expansion is necessary if all the existing stump wood is to be utilized before fire and rot render it worthless. The immediate war outlook for naval stores might justify an expansion of the wood naval stores industry, if equipment were available. In the postwar period, however, overproduction of gum rosin and turpentine can be expected. Furthermore, a growing production of sulfate turpentine by pulp mills is also likely.

\section{Spanish Moss Ginning}

Harvesting, curing, and marketing Spanish moss (Dendropogon usenoides) has been a profitable industry in
Louisiana forests for more than half a century. In the Census of 1880 (Sargent's Report on the Forests of North America) it was reported that for the year ending August 31, 1881, New Orleans alone received about 10 million pounds of rough moss, valued at $\$ 315,000$, and shipments to other markets brought the total value of the moss output in the State to about $\$ 550,000$.

Spanish moss is a true epiphyte (air plant) and grows in quantities upon cypress, oaks, and other trees in the bottom lands, especially in the hardwood and cypress swamps in the southern part of the State. There are no estimates of the quantity of moss in the State, but it reproduces very rapidly and no evidence has been noted of a decrease in the supply. Some local residents report that, as the virgin timber has been cut and replaced by more open secondgrowth stands, the quantity of moss has increased.

Its tough fibrous tissue makes Spanish moss commercially important for upholstery, mattresses, and similar products. The moss is gathered by inhabitants of the swamp as a part-time activity associated with fishing, trapping, subsistence farming, etc. In some cases mossgathering rights on tracts of timber are purchased, but most moss harvesting is done without obtaining definite permission from the landowner. After the moss is gathered and air cured, it is sold to a moss gin for processing and resale to manufacturers. In 1937 more than 30 moss gins were operating in the State, and the total value of the products sold in that year is estimated at more than 1 million dollars. About a quarter of a million man-days of labor was required to gather and gin the moss.

\section{Selective Cutting and Integrated Use}

Since most of the saw timber can be manufactured into the more valuable commodities, such as lumber and veneer, production of such low-grade products as fuel, fence post, and pulpwood should be confined wherever possible to inferior species, cull trees, upper stems of sawlog trees, and small trees that should be removed as thinnings. If all or a large part of the volume in cull trees could be removed, it would improve the character of the forest materially and enhance the rate of growth of the remaining trees. Likewise, many young timber stands are in need of thinning operations that would remove some of the smaller trees and leave the high-quality and most rapid growing trees for later removal as sawlogs. An enlarged market for small poles is needed so that thinnings can be sold at higher prices than they bring as fuel or pulpwood. Forestland owners must understand how much more profit they will gain from marketing the high-quality material as sawlogs, veneer logs, etc., and from cutting the low-quality material into fuel, pulpwood, and like products. 
In the bottom lands there are large quantities of maple, sweetbay, water tupelo, and other soft-textured hardwood timber, much of which is not of a quality suitable for lumber, veneer, or other timber products. Utilization of this material has been slow to develop because of lack of market. The establishment of pulp mills that could use these lowvalue species and poor-quality trees as a source of raw material would be a boon to timberland owners.

Studies made by the Southern Forest Experiment Station indicate that in certain forest types good returns may reasonably be expected under such a plan of selective cut- ting and integrated use. Growth studies show that the annual increment per acre of second-growth stands on large tracts in the upper Coastal Plain (composed mansl? of shortleaf and loblolly pines) is as high as 201 board teet, of which 186 board feet is pine and 15 board feet hardwoods. A 10-year period of return may be adopted, since volumes as low as 500 board feet per acre can be removed with trucks at only slightly higher logging costs per M board feet than volumes of 2 to $4 \mathrm{M}$ board feet per acre. In this way, the nonearning and low-earning timber may be removed whenever it can be sold profitably for such uses

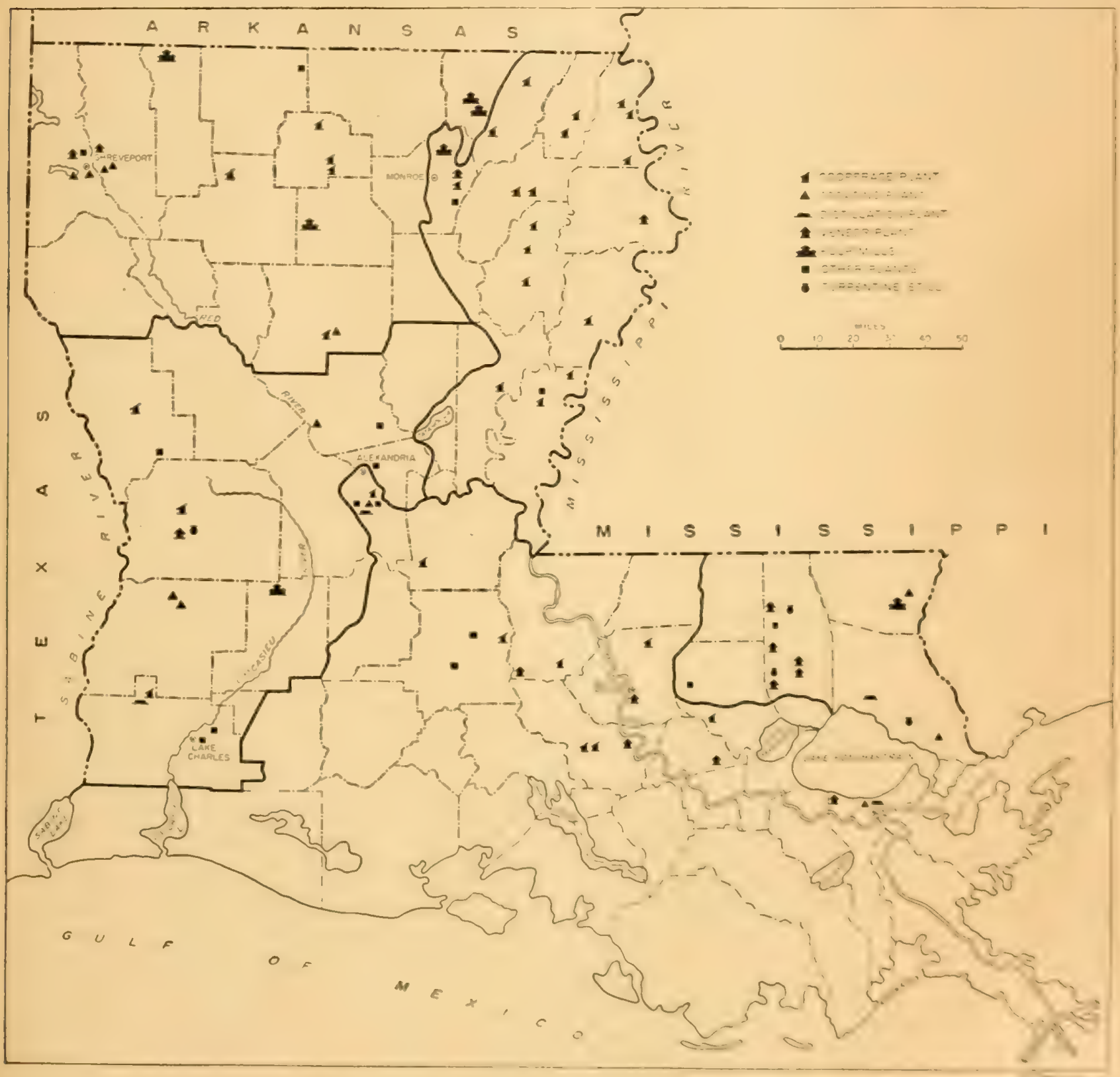

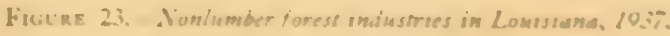


as pulpwood or fence posts or fuel wood, and the rapidly growing, higher-earning timber may be reserved until it approaches financial maturity - that point at which, under existing market conditions, it will afford the best returns to the owner.

Southern Forest Experiment Station research in the shortleaf-loblolly pine type has demonstrated that under selective cutting, in which only the more mature and the defective trees are removed, higher grades of lumber and considerably higher prices per $\mathrm{M}$ board feet cut are obtained than when clear cutting is practiced. Lower logging and milling costs per $\mathrm{M}$ board feet usually result. Selective cutting in this type aims at better forestry but also at

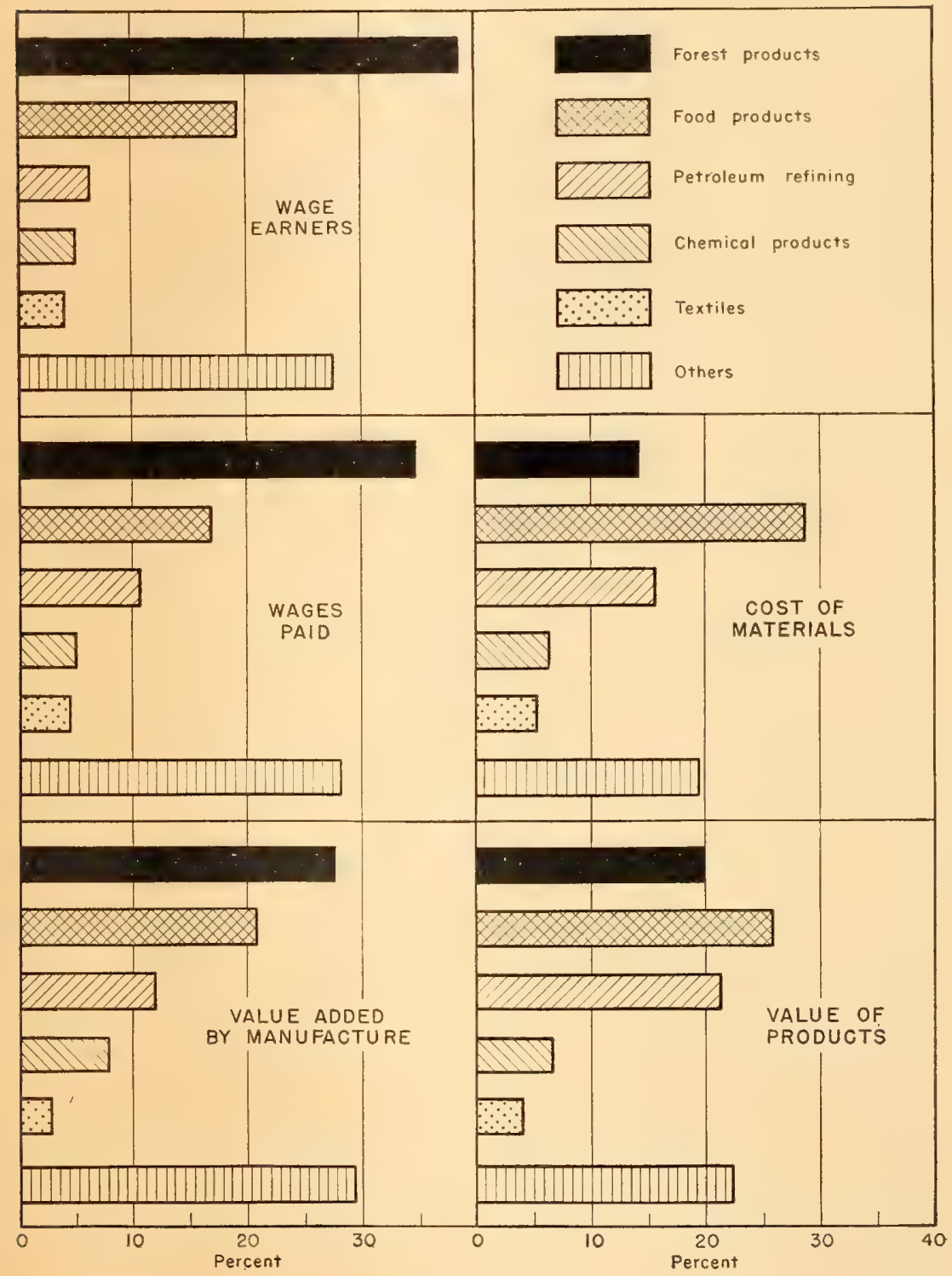

increased profits. Although definitive studies have not been made in the hardwoods, it is believed that the selective system of cutting is also applicable to these forests. In longleaf pine alone this system of tree selection does nut usually reproduce a longleaf pine forest. This species requires full light and open stand conditions for successful reproduction. Therefore, one or another of these systems must be used: (1) clear cutting and planting, (2) clear cutting with groups of seed trees, or (3) a group-selection system in which small scattered areas are clear cut. The successful use of any of these systems depends upon the protection of the reproduction from hogs.
FIGURE 24.-Rank of principal groups of manufacsuring industries in percent of all within the State, 1937. With each class is included all allied or kindred industries. The predominance of forest products in earners, wages, and value added by manufacture is of considerable significance. 
Figure 25.-Man-days of employment furnished by the principal forest industries in the different survey units, 1937.

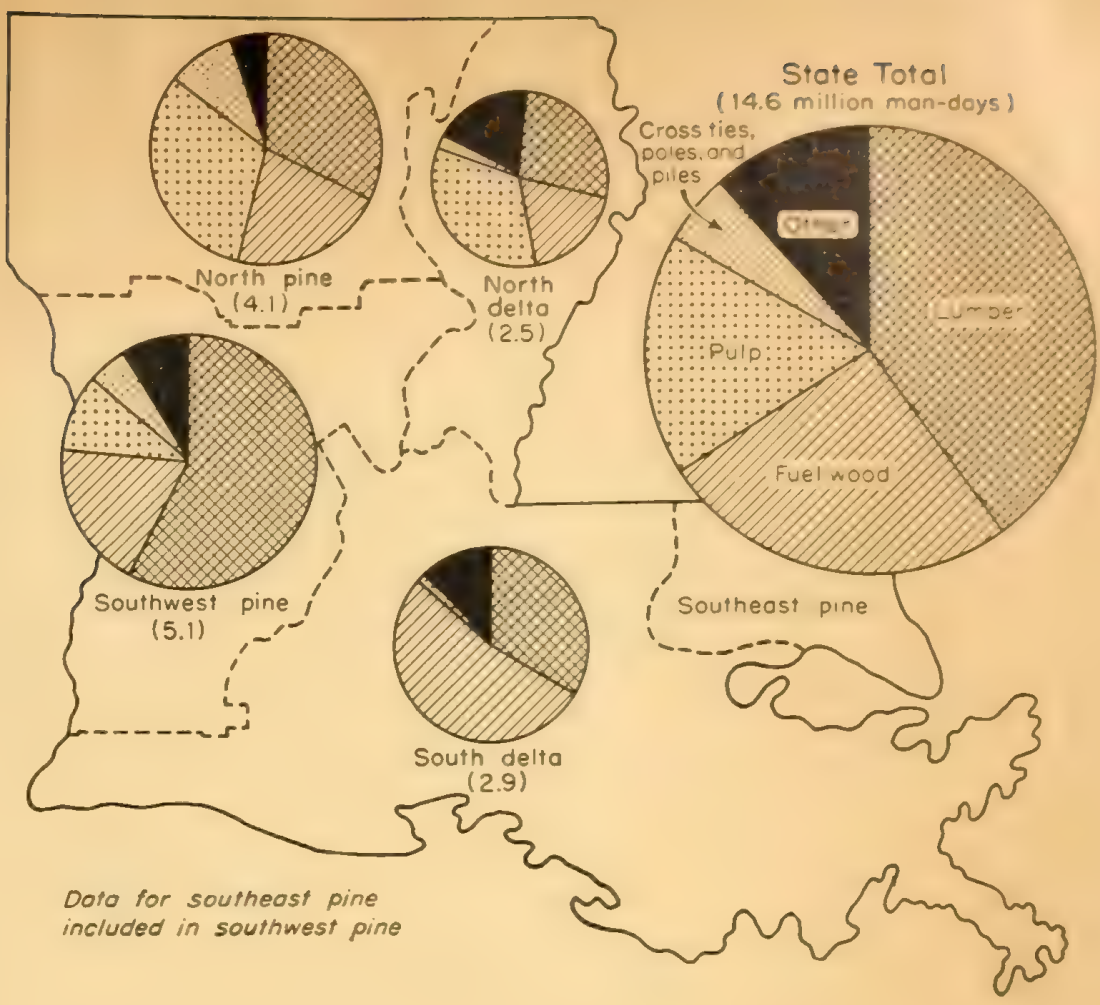

\section{Employment}

Within Louisiana the forest industries have long overtopped any other group of manufacturing industries as a source of employment and wages, notwithstanding the development in recent years of the mineral industries. The United States Bureau of the Census found that in 1937 the forest-products industries in the State accounted for 39 percent of all the wage earners employed in manufacturing and 35 percent of the money paid in wages by manufacturing industries (fig. 24).

By providing a large amount of employment for the people of the State, the forest industries make one of their greatest contributions to the general welfare. Furthermore, in the forest-products industries a larger proportion of the manufacturing expenditure goes for wages than in any other major manufacturing group in the State. Since these industries are not likely to become more highly mechanized, any increase in the manufacture of forest products will presumably add to employment.

One of the aims of the survey has been to determine the extent and character of the employment provided by the forest industries. Because the number of working day's per year varies greatly and because certain classes of laborers work only part time, it is difficult to express this employment in man-years or in number of men employed.
Estimates were therefore made on the basis of 8-hour mandays.

The manufacture of lumber, including woods work, accounts for 40 percent of the total forest-industryemployment (fig. 25 and table 11). The second largest source of such employment is the cutting of fuel wood, both for sale and for home consumption. Although probably nine-tenths of the fuel-wood cutting provides no cash income, it supplies a necessity that would otherwise require a cash outlay. The pulp and paper industry ranks

TABLE 11.-Distribution of mandays of employment in the principal forest industries, by surcey units, 1937 1

\begin{tabular}{|c|c|c|c|c|c|}
\hline survey unit & $\left|\begin{array}{c}\text { Total } \\
\text { emplong- } \\
\text { mint }\end{array}\right|$ & Lumber & $\begin{array}{l}\text { Fuel } \\
\text { wond }\end{array}$ & Pulp & Other \\
\hline & $1 .(x)$ & & & & \\
\hline & mun-days & Percent & Percent & Prreen? & Iverene \\
\hline North delts..... & 2530 & $2 \times 5$ & $18+$ & 53. 8 & 19. 3 \\
\hline Enuth clelta. & 2.910 & 38.4 & 33.0 & & $M x$ \\
\hline North pine ... & $4,|:|$ & 32.1 & 21.5 & 31.9 & $\$ 11.5$ \\
\hline Southwest pines. & 3.064 & 37.7 & 188 & 9. 6 & 13. y \\
\hline All units ... & $|14.853|$ & 3091 & 23.91 & 17 & If 1 \\
\hline
\end{tabular}

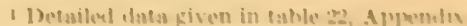

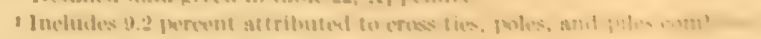

'Includes tata for southemst wine moit.

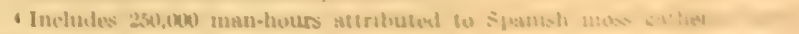
ginumg. 


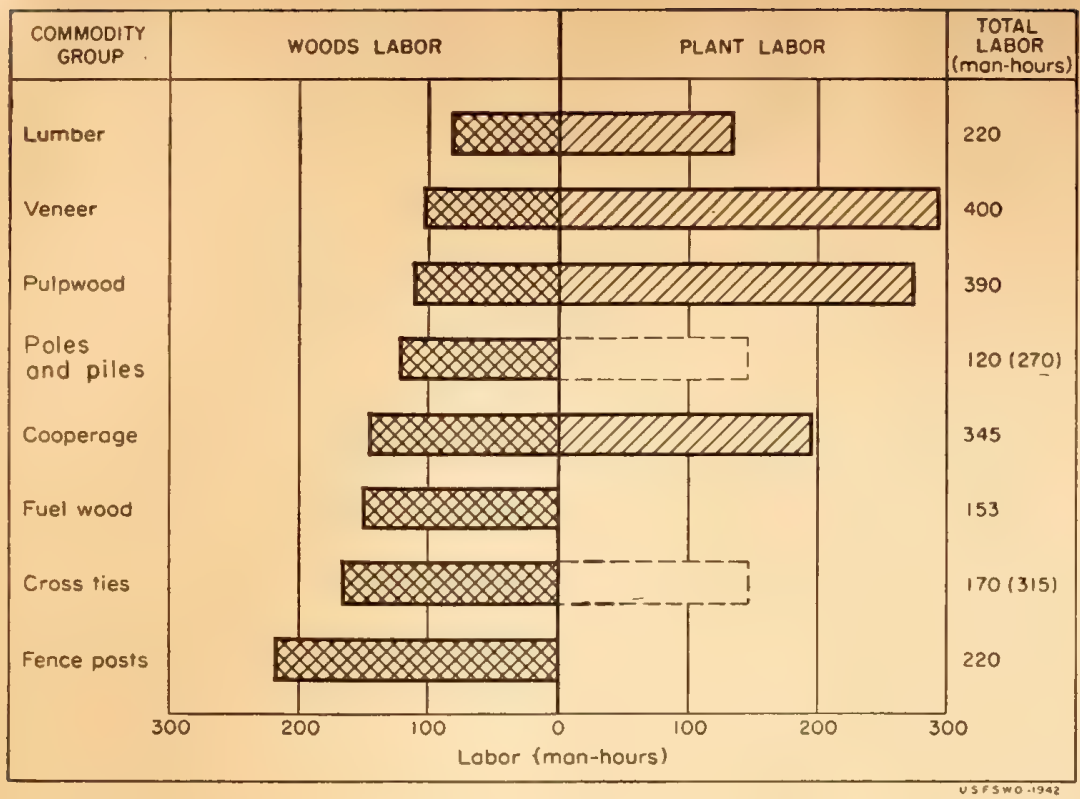

FIGURE 26. - Labor requirements for producing various commodities from 1,000 cubic feet of wood, 1935-37. (Plant labor requirements shown for poles and piles and for cross ties represent preservative treatment; included in total in parentheses.)

third, accounting for 18 percent of all forest employment. It is noteworthy that the 6 pulp mills in operation in 1937 provided nearly half as much employment as the 557 sawmills.

The amount of forest employment varies considerably among survey units; it is greatest in the two south pine units combined and least in the north delta unit. There is a marked difference among the units also as to relative contribution of the sources of employment. In 1937 the lumber industry provided about 58 percent of the total of such employment in the south pine units as contrasted with 28 to 33 percent in the other units. The pulp and paper industry provided about one-third of the total in the north pine and north delta units; in the former, it provided nearly as much as the lumber industry. Veneer manufacture is an important source of employment chiefly in the two delta units, cooperage manufacture mainly in the north delta, and production of cross ties, poles, and piles in western Louisiana.

The labor requirement for converting 1,000 cubic feet of wood into different forest products varies from 120 man-hours for untreated poles and piles to 400 man-hours for veneer (fig. 26). Owing largely to the use of mechanical equipment, production of sawlogs requires the smallest relative amount of labor in the woods (85 manhours)-much less than that required for products that are stacked, peeled, split, or hewn by hand. The manufacture of veneer takes a few more man-hours per 1,000 cubic feet of wood than does the manufacture of paper or paperboard from pulpwood. Preservative treatment about doubles the labor requirements of producing poles, piles, and cross ties.

It must be kept in mind that lumber, veneer, and cooperage stock are only semifinished products, as, indeed, are some others. In expanding the manufacture of cellulose products, or further refining or fabricating products previously sold in semimanufactured form, many manhours may be added to the total employment provided by the forest industries. 


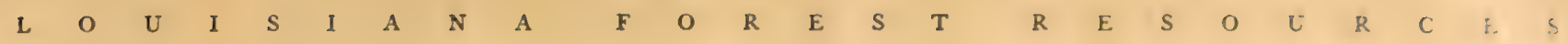

\section{Forest Increment and Drain}

\section{Net Increment}

A FOREST is a perpetually changing association of trees in which growth tends to offset losses. While natural growth is almost ceaselessly adding to the volume of timber, other factors-natural and man-causedare continually causing reductions. Net increment, or the net gain from the action of natural factors alone, represents in a general way the quantity of wood that could be cut within the period covered by the calculations without reducing the growing stock, or forest capital. This may in some instances, of course, be nil or, if the mortality loss exceeds growth gain, a minus increment. It is against this net increment that the loss from timber cutting, or commodity drain, must be charged.

The Forest Survey estimates that the gross increase in the saw-timber volume of Louisiana forests during 1937 was 2.4 'billion board feet; against this there was a mortality loss of 0.5 billion board feet, leaving a net increment of 1.9 billion board feet (table 12). Although pines constitute only about a third of the total growing stock, they account for more than half the total net saw-timber increment. Their

TABLE 12.-Net increment of pines and hardwoods in Louisiana, expressed in board feet, cords, and cubic feet ${ }^{1}$

\begin{tabular}{|c|c|c|c|}
\hline Species & Growth & Mortality & $\begin{array}{c}\text { Net } \\
\text { increment }\end{array}$ \\
\hline & $\begin{array}{l}\text { Billion } \\
\text { board feet }\end{array}$ & $\begin{array}{l}\text { Billion } \\
\text { board feet }\end{array}$ & $\begin{array}{l}\text { Billion } \\
\text { board feel }\end{array}$ \\
\hline Pincs ............... & 1.16 & 0.14 & 1.02 \\
\hline Hardwoods (erpress). & 1.25 & 35 & .90 \\
\hline \multirow[t]{2}{*}{ All species... } & 2.41 & .49 & 1. 92 \\
\hline & Mfillion cords & Mullion cords & Mullion cords \\
\hline Pines ........... & 3. 7 & 0.5 & 3. 2 \\
\hline Mardwoods... & 3. 5 & 1.7 & 3.8 \\
\hline \multirow[t]{2}{*}{ All species. } & 9.2 & 2.2 & 7.0 \\
\hline & $\begin{array}{c}\text { Millinn rubic } \\
\text { feet }\end{array}$ & $\begin{array}{c}\text { Million cubic } \\
\text { feet }\end{array}$ & $\begin{array}{c}\text { Million cubic } \\
\text { feet }\end{array}$ \\
\hline Pines ....... & $\quad 279$ & 41 & 235 \\
\hline Il ardwoods. . & 385 & 114 & $27 !$ \\
\hline All sprecies & 6مM & 155 & $\sin )$ \\
\hline
\end{tabular}

1 1)ata by regions are given in tables :4-20, . Ippentis. larger net increment is due primarily to their more rapid rate of growth, and secondarily to their lower mortality rate, which in 1937 was 0.93 percent as compared with 1.33 percent for hardwoods and cypress.

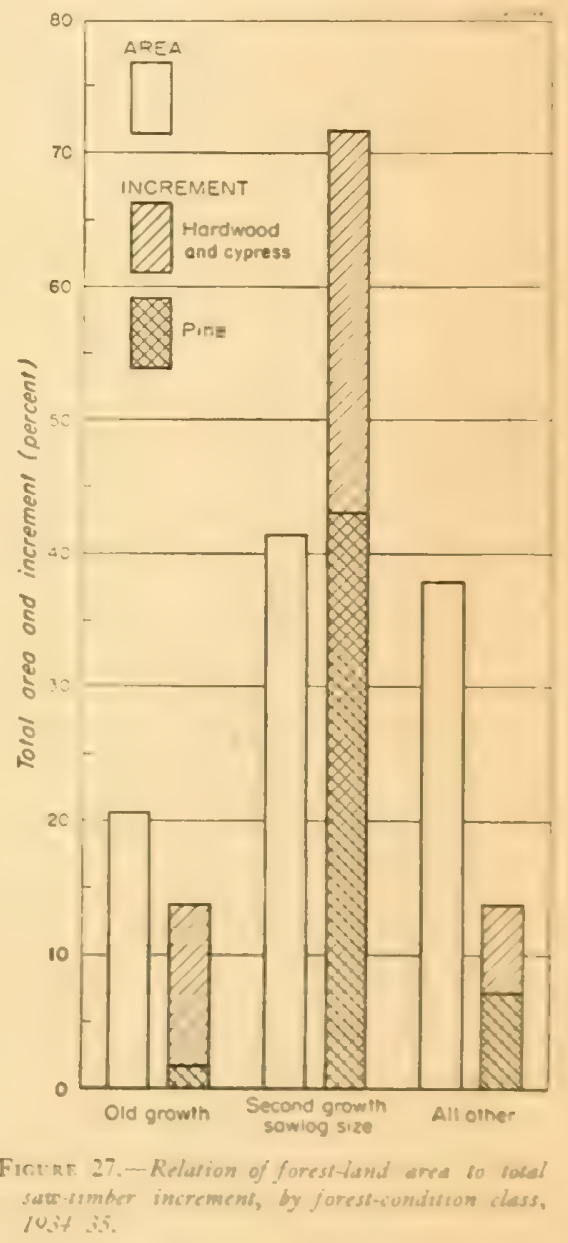

During that year, if no cutting hat taken place, the saw-timber volume within the state would have increased by 4.6 percent, or an average increment per acre for the entire forest area of 119 board feet. In 19.4 and 10is the second-growth sawlog-size stands, hecause of good stucking and general thrift, had an aler.yee t. 
growth equivalent to more than 200 board feet per acre annually. Thus, although these stands accupied only 41 percent of the forest area, they contributed 72 percent of the total board-foot increment (fig. 27).

It is significant from the point of view of the pulp and paper industry that the net pine increment in 1937 was more than 3 million cords (table 12). Not all of this increment, however, is destined for the pulp mills; it is available for other industrial uses, and the pulp makers must compete for it on a price basis with the lumber manufacturers and the dealers in poles, piles, posts, and other pine products, As a matter of fact, the demand for saw timber was so keen in 1937 that there was cut for this purpose alone 8 percent more cubic volume of pine wood than was added through growth.

The total net increment of the growing stock 5.0 inches d.b.h. and larger (excluding bark) in 1937 was 509 million cubic feet, fairly equally divided between pine and hardwood (table 12). Net increment during the year on a cubic-foot volume basis averaged 4.3 percent, or about 31 cubic feet per acre.

\section{Commodity Drain}

Commodity drain, as distinguished from mortality drain, is the growing-stock material cut from the forest, whether fully utilized or not. In the early history of Louisiana, commodity drain consisted in large measure of hewed timbers and rough lumber used for strictly local building purposes. The economic development of the State broadened the demands on the forests for timber. Cross ties were needed by the railroads; industrial lumber was needed for use locally and in many other parts of the Nation; and, particularly within recent years, important amounts of wood have been required for cellulose products.

The total commodity drain from saw-timber growing stock in 1937 was 2.3 billion board feet (table 13). This includes material shipped outside for manufacture. Of the saw-timber material harvested, 65 percent went into lumber. Although the fact may not be commonly known the second largest part of the material suitable for sawlogs is used as fuel wood; this use accounted for about 12 percent of the drain of sawlog material. Cross ties, veneer,

TABLE 13.-Commodity drain, in sawlogs, cords, and cubic feet, $1937^{1}$

\begin{tabular}{|c|c|c|c|}
\hline Species & Saw timber & $\begin{array}{l}\text { Cordwood } \\
\text { with bark }\end{array}$ & $\begin{array}{l}\text { Total volume } \\
\text { inside bark }\end{array}$ \\
\hline & $\begin{array}{l}\text { Billion board } \\
\text { feet }\end{array}$ & Million cords & $\begin{array}{l}\text { Million cubic } \\
\text { feet }\end{array}$ \\
\hline Pines_....... & 1. 2 & 3.4 & 259 \\
\hline Hardwoods . $_{\text {. }}$ & 1.1 & 2.9 & 208 \\
\hline All species_. & 2.3 & 6.3 & 467 \\
\hline
\end{tabular}

1 Detailed data by survey units are given in tables 23-25, Appendix.

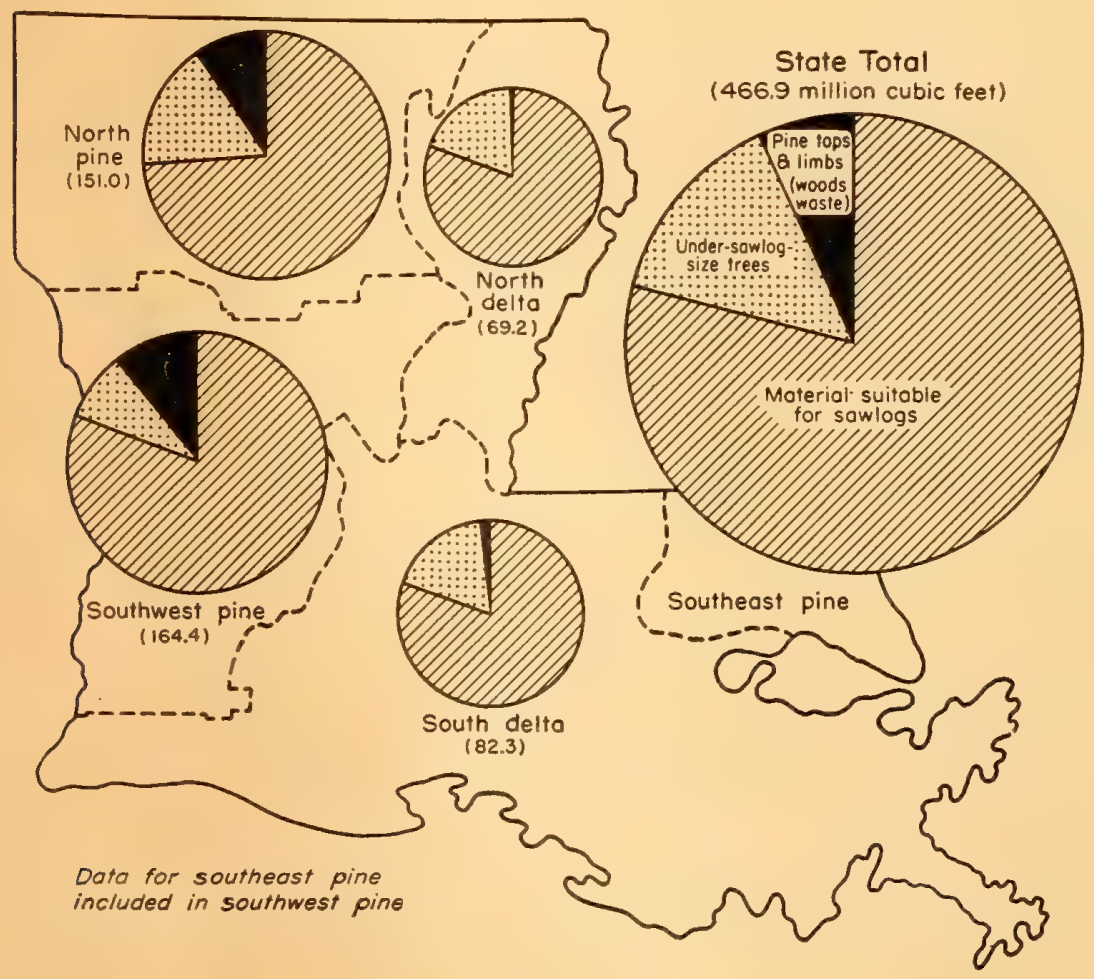

Figúre 28.-Commodity drain on the growing stock, by class of material and survey unit, 1937 
FIGURE 29.-Comparison of net increment and commodity drain for sawlog timber and all trees, 1937.

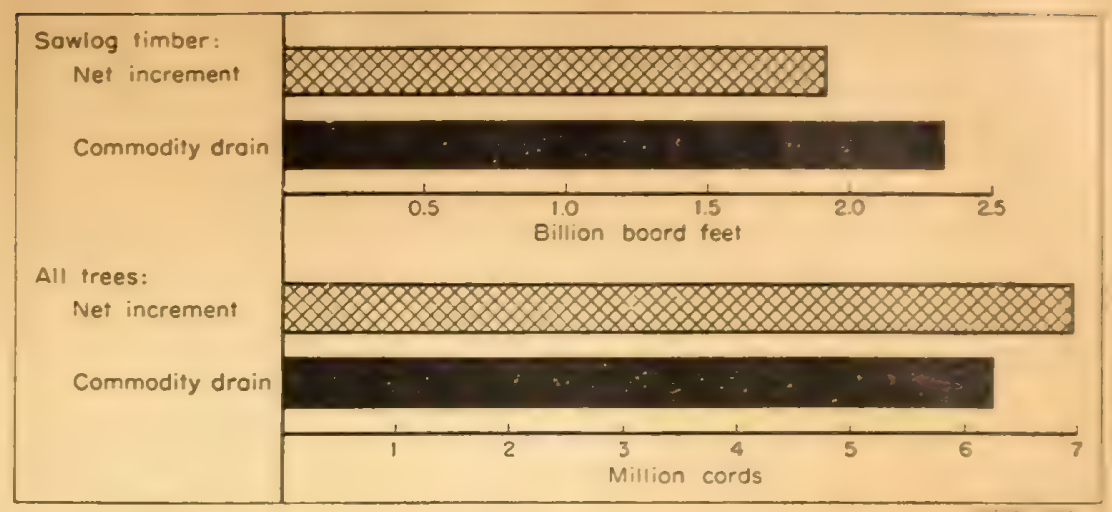

Of the total drain of saw timber from Louisiana forests in 19.37, more than 17 percent was mortality loss; that is, onefifth as much saw timber was lost by death as was cut for use (fig. 29). Since by far the most important cause of mortality is fire, mortality loss could be reduced greatly by more effective protection from forest fires. Improved forest-management practices and more intensive utilization would help to serve the same purpose.

\section{Comparison of Net Increment and Commodity Drain}

In 1937, a peak year of lumber production in Louisiana, the total commodity drain from saw-timber material was more than 2.3 billion board feet and the total net increment, after deduction for mortality, was 1.9 billion. This means that during the year the total stock of sawlog mate-

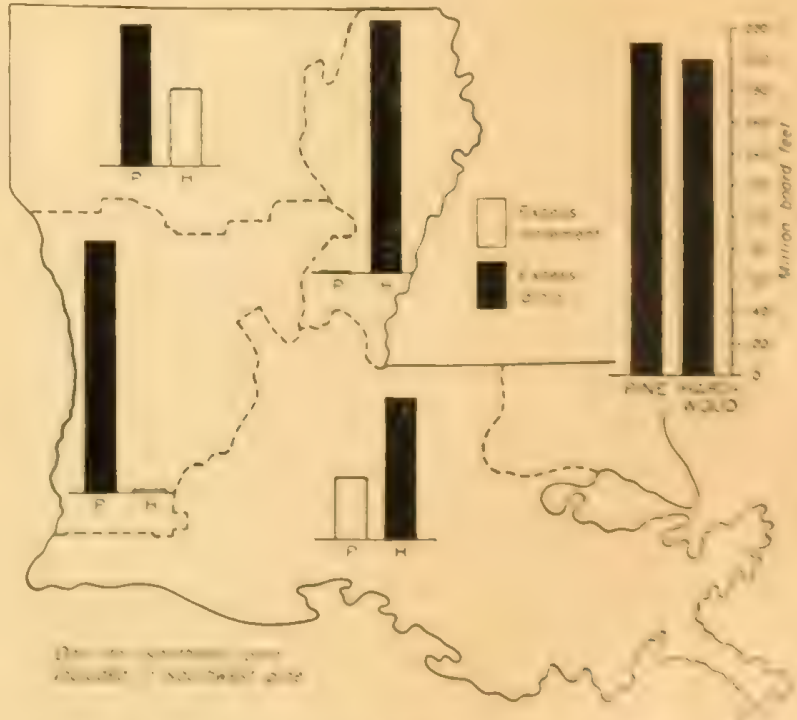

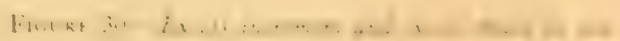
$\therefore, \ldots, \cdots$ 
rial growing in the forests was reduced by more than 400 million board feet. The decrease was about evenly divided between pines and hardwoods (including cypress). The pine-hardwood ratio varies among different sections of the State (fig. 30; see also table 24, Appendix).

If all trees 5.0 inches $\mathrm{d} . \mathrm{b}$. h. or larger are considered, however, the total net increment exceeded the total commodity drain by 700,000 cords or 42 million cubic feet (tables 24 and 26, Appendix). This excess was due largely to net increment in the under-sawlog-size trees, which far exceeded the volume cut from them. In pine trees under sawlog size, net increment exceeded drain in spite of heavy cutting for pulpwood, but not enough to offset the deficit in trees of sawlog size; the total pine commodity drain for all sizes exceeded the net pine increment by about 264,000 cords. In the hardwoods and cypress, on the other hand, net increment in the smaller trees so greatly exceeded the corresponding drain as to offset the decrease in hardwood and cypress trees of sawlog size and add besides nearly a million cords to the growing stock. Much of this net increment in hardwoods, however, was in inferior species and in stands of poor quality, while cutting was mainly confined to the better species and to high-quality trees.

In no subsequent year has the lumber cut equalled that of 1937 , or the comparison of increment and drain been darker. Nevertheless, from timber volume, net increment, and commodity drain data, certain definite statements can be made regarding the future of the established forest industries. The period of operation of most of the larger, better equipped sawmills which depend chiefly upon oldgrowth timber is definitely limited. Their places will be taken by plants that can use second growth, such as pulp mills, small sawmills, and (in the hardwoods) stave and tie mills. This situation probably will involve a reduction of aggregate employment, so that a loss in populationsupporting capacity of the forest area will gradually come about. In parts of the State, notably in the bottom lands of the principal streams, agricultural development can absorb some of this population. In others the loss of forest employment will create a serious social problem. Since overcutting of sawlog stands in Louisiana is most widespread in the north delta and south pine units, these localities will be most seriously affected by loss of forest industries.

There now appears to be no practicable means of evading this problem; too many sawmills have only a limited supply of operable timber left. Prompt action is necessary to restore productivity to the depleted forest areas and, through prudent and conservative use, to maintain the productivity of areas now growing timber. An excellent start in this direction has already been made by some of the private forest-land owners, but, considering the size of the job yet to be done, it is only a start. Millions of acres of forest land still need to be brought under the provisions of a definite forest program. 


\section{Perpetuating Louisiana's Forests}

$\rightarrow 28$

$\mathrm{T}$ HE FOREST lands of Louisiana should be made to contribute their full share to the economic advancement of the State. The virgin forests of the State have played an important part in its development and, now that most of these stands have been cut, the second growth timber can assume just as important a role in the years to come. In any program to expand and diversify the manufacturing industries, utilization of forest resources should logically have a prominent place. Forest industries require a large volume of labor per dollar unit of product, and the growing tendency toward more complete fabrication will increase not only the opportunity for labor but the cash returns as well. The safe limit in expansion is determined by the capacity of the State's forests, through growth, to sustain forest industries indefinitely.

Informed forestry practice is essential to increase the volume and the quality of the forest resource. The new forests must be handled wisely and with restraint. Many problems remain to be studied. Moreover, the forest lands are owned by thousands of individuals having differ ent objectives of management and various economic limitations. To build the forest resource up to what might be termed a reasonably good condition will take years of planned action, with close cooperation between owners of forest land, the State, and the Federal Government.

In efforts to improve the forest situation of the State the objectives should be: (1) To build up the growing stock so as to obtain at lowest cost the maximum sustained increment of wood, in forms suitable for the most valuable commodities; (2) to prevent losses caused by fire, theft, insects, and disease; (3) to develop stable and diversified wood-using industries throughout the State that will provide profitable markets for all the products and byproducts of the forest; and (4) to give forest-land ownership more stability and appeal by eliminating, or adjusting, unfavorable factors such as inappropriate tax treatment, discriminatory freight rates, severe credit terms, and restrictive legislation.

The forest industries, the public, and the forest-land owners all have a large interest in the program and should cooperate to the fullest extent in order to obtain (1) the legislation and appropriations needed to put it completely into operation and (2) the forest practice necessary to perpetuate it. The discussion that follows is not intended to cover all the action needed but to focus attention on some of the important steps that should be taken. The program which follows envisages a peacetime economy and the long-term character of the forest enterprise. If some of the recommendations are not in accord with wartime requirements, they are obviously nonapplicable for the present.

\section{What Forest Owners and the Forest-Using Industries Can Do}

1. Private owners should extend fire protection to all their forest lands. To this end, they should take full advantage of the cooperative facilities offered by the State and Federal Governments.

2. Forest owners should build up the quantity and quality of growing stock of their lands by limiting cut to less than increment, by appropriate cutting methods, and by integrated use, and, in some cases, by artificial reforestation. In southeast and southwest Louisiana are large areas of denuded forest land that must be planted if they are to be brought back to acceptable stocking within a reasonable period. Planting is desirable also on some areas of poor reproduction and in some abandoned fields.

3. Forest industries should as far as possible practice integrated wood utilization. The high-grade portions of trees should be converted into lumber, poles, piles, and other quality products; low-grade portions should go into pulpwood, fuel wood, and other commodities with less exacting requirements.

4. Supplementary uses of private forest land, such as hunting, trapping, and tishing, should be developed in orter to make it earn additional income. Lumisiana has nut made so much progress as some other southern Stutes developing recreational and game pussibilitics of iorest lands; however, the State has exceptionally large rexcrves of petroleum, natural gas, and other subs- _ _.... - 
These often furnish sufficient income to pay forest administrative costs plus a good return on the capital investment and thus leave the income from the forest resource as a net gain. In such cases, the landowners should be alert to possibilities of increasing forest returns through proper care and use of their timber.

5. Forest-land owners, particularly those with small holdings, should consider the advantages of organizing themselves into cooperative associations. Such organizations should employ technicians to advise and assist woodland owners in applying sound forest practices to their land, should develop more favorable marketing opportunities for forest products, and make more effective the influence of their members in public affairs. Cooperatives of this kind could also assist Federal and State agencies in administrative and research work such as the organization of fire-protection associations and economic studies of timber growing and manufacture.

\section{What the State Can Do To Assist}

1. A foremost forestry objective of the State should be to provide fire protection for all forest lands. Since the public, in one way or another, is directly or indirectly responsible for a large proportion of the forest fires, the State should assume a large share of the responsibility of fire prevention and suppression. Adequate State funds should be granted to supplement Federal funds under the Clarke-McNary Act and a sufficiently large and fully trained protection organization should be maintained. Through an educational campaign the public should be made aware of the character and magnitude of forest losses through uncontrolled fires.

2. The State in cooperation with the Federal Government should give particular attention to increasing extension activities which carry to forest-land owners the principles of forestry, including both silviculture and utilization. This assistance can be expanded by enlargement of the State division of forestry, through employment of more extension foresters by the Agricultural Extension Service, and through additional instructions in forestry in the public schools. The recently established State system of demonstration forests should be extended to serve the largest possible number of smaller forest-land owners. Forestry extension is needed particularly in the Mississippi River Delta, where scientific forestry has not yet made as much progress as in other parts of the State.

3. The general industrial planning program, which is making impressive headway in the State, should weave the forest industries into the industrial pattern of each section of the State. As a part of such a program, some State agency should give intensive study to the forest situation in order to determine the location and distribution of forest industrial plants that will develop maximum benefits from the forest resource. Until smaller areas are defined, the five Forest Survey units used in this report might serve as regional areas to be studied.

4. State nursery facilities should be enlarged to furnish forest planting stock to landowners at low cost. Sufficient funds also should be made available to the State division of forestry to provide expert supervision of planting operations, particularly in southwest Louisiana.

5. Tax laws and practices should be reviewed for the purpose of bringing to light any unnecessary obstacles to timber growing and the establishment of stable forest communities. It may be that the exising special forest tax law should be superseded or revised in such a manner that more forest lands will be directly benefited. In any case, the question of tax administration is an important one and much is to be gained, whether or not there is new legislation, by convincing parish officials of the long-run benefits to their communities in a sympathetic approach to taxation of lands under forest management.

6. Because normal cutting is depleting the saw-timber volume on private lands in the State, thus threatening the future of the forest industries and the jobs they provide, attention should be given to public control measures in order to maintain and build up the forest stand. Of a total of 16 million acres of forest land, less that 2 million acres are handled under a system of management where the forest capital is being maintained or increased.

7. The State should enforce better observance of the property rights of private forest-land owners, in order to reduce timber thefts, incendiarism, and other forms of trespass and damage.

\section{What the Federal Government Can Do To Assist}

What the Federal Governiment could do to assist is clearly indicated in the recommendations of the Joint Congressional Committee on Forestry, submitted to the 76th Congress, March 24, 1941. The following recommendations for the State of Louisiana are adapted from the summary of that report:

1. Increase its appropriations for cooperative fire protection under the Clarke-McNary Act. At present Federal funds are not sufficient to match the State and private funds offered for cooperative fire-protection effort. Local interest and contributions can definitely be stimulated by greater Federal participation.

2. Support an adequate educational program in cooperation with the State to assist the owners of forest land in 
solving their technical forest-management problems. Present forest extension effort is inadequate. Additional funds, as these are provided, will make possible the employment of extension foresters to work with farm woodland owners, and the addition of two or three Federal employees to the staff of the State forester to work with other forestland owners.

3. Make possible long-term, low-interest bearing loans on sound forest enterprises. Revision of cutting practices to build up the growing stock, purchase of land, or improvements in manufacturing facilities often require cash outlays that some of the companies are unable to make. Timbergrowing is a long-term business, and large amounts of capital at low interest rates are frequently needed by owners wishing to cut their forest conservatively or to undertake sustained-yield management.

4. Provide increased research on locally important problems. Among these are the silviculture and utilization of hardwood stands, both in the Delta bottom lands and in the upland hardwood areas. Technical knowledge required to formulate sound management practices for hardwood forests is lacking. Timber-growing conditions in the Delta are generally favorable, and the application of sound practices should greatly increase the rate of rimber growth and the yield of high-grade forest products. Research to develop new uses for all naval stores products should be expanded in order to stabilize the production of and increase the peacetime demand for wood and gum naval stores.

5. Consider reinventorying the forest resource of the State about 1945, in cooperation with State planning agencies, to bring up to date the present findings. This reinventory should be more detailed than the one made in 1934-35, and should provide estimates of forest area and timber volume by parishes.

6. Acquire lands for forest purposes, such as those submarginal for farm crops and not likely to attract private, State, or community ownership, needed to control run-off and erosion, necessary to block up national forests or purchase units where effective management is made difficult by intermingled holdings of other owners, or essential to assure locally a permanent forest economy.

7. Assume responsibility in putting into effect sufficient public control over private forest lands to stop any destructive cutting practices and insure such handling as will keep them reasonably productive.

\section{Appendix: Supplemental Tables}

TABLE 15.-Land area classified by major use and survey unit, 19.3t-35

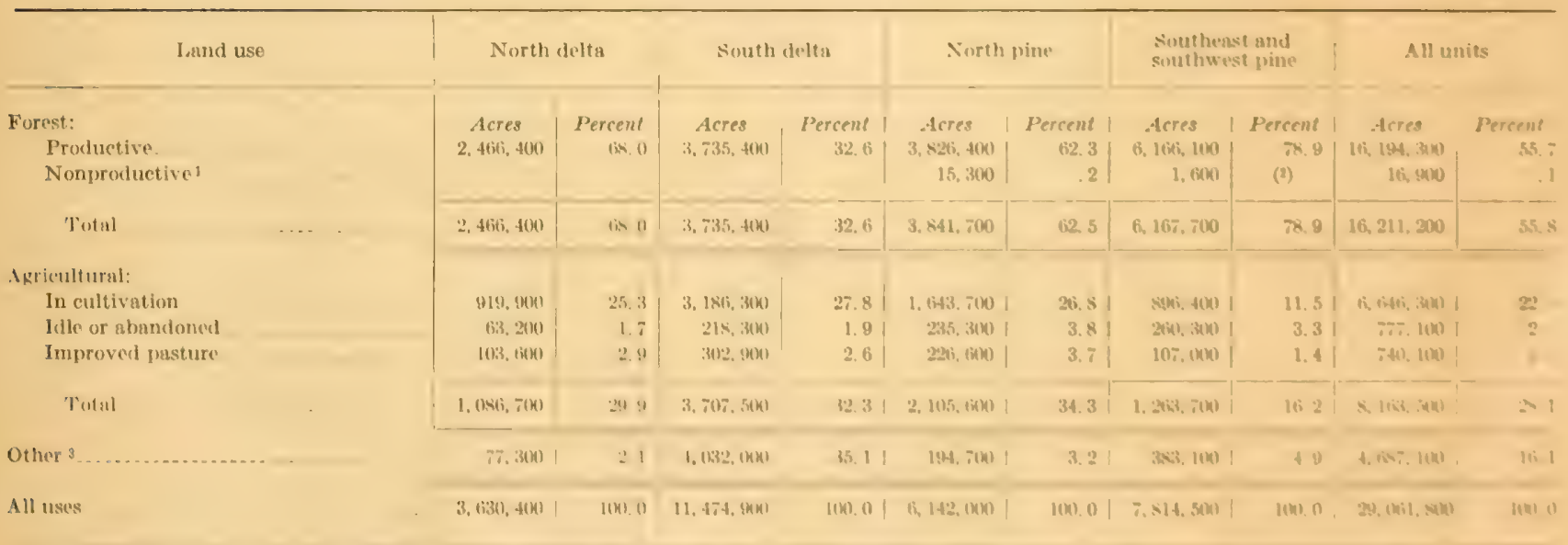

I Nonproductive forest Innd included with productive forese lanel in the dolta units; 25,300 acres in the north delts, $81,2(6)$ neres in the south dedte.
Visglisitules.

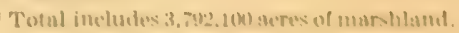


TABLE 16.-Forest area classified according to forest-type group and forest condition, 1934-35

[Thousand acres; i.e., 000 omitted]

\begin{tabular}{|c|c|c|c|c|c|c|c|c|}
\hline \multirow{2}{*}{ Forest-type group and survey unit } & \multicolumn{2}{|c|}{ Old-growth } & \multicolumn{2}{|c|}{ Second-growth sawlog-size } & \multirow{2}{*}{$\begin{array}{l}\text { Second- } \\
\text { growth } \\
\text { under- } \\
\text { sawlog-size }\end{array}$} & \multirow{2}{*}{$\begin{array}{l}\text { Reproduc- } \\
\text { tion }\end{array}$} & \multirow{2}{*}{$\begin{array}{l}\text { Clear-cut } \\
\text { and } \\
\text { fire-killed }\end{array}$} & \multirow{2}{*}{$\begin{array}{l}\text { All } \\
\text { conditions }\end{array}$} \\
\hline & Uncut & Partly cut & Uncut & Partly cut & & & & \\
\hline $\begin{array}{l}\text { Longleaf and slash pines: } \\
\text { South pine. }\end{array}$ & 75.6 & 124.8 & 226.6 & 64.5 & 538.9 & 279.7 & $1,247.9$ & $2,558.0$ \\
\hline $\begin{array}{l}\text { Shortleat-loblolly pines and shortleaf-lob- } \\
\text { lolly pines-hardwoods: } \\
\text { North delta } \\
\text { South delta } \\
\text { North pine. } \\
\text { Southeast and southwest pine }\end{array}$ & $\begin{array}{r}14.8 \\
61.1 \\
25.4\end{array}$ & $\begin{array}{r}1.7 \\
6.1 \\
86.0 \\
53.7\end{array}$ & $\begin{array}{r}10.9 \\
155.4 \\
1,029.1 \\
927.8\end{array}$ & $\begin{array}{r}5.9 \\
54.1 \\
774.4 \\
405.9\end{array}$ & $\begin{array}{r}6.7 \\
69.9 \\
540.7 \\
640.9\end{array}$ & $\begin{array}{r}1.7 \\
10.5 \\
49.0 \\
64.5\end{array}$ & $\begin{array}{r}1.7 \\
4.3 \\
32.1 \\
39.8\end{array}$ & $\begin{array}{r}28.6 \\
315.1 \\
2,572.4 \\
2,158.0\end{array}$ \\
\hline Total & 101.3 & 147.5 & $2,123,2$ & $1,240.3$ & $1,258,2$ & 125.7 & 77.9 & $5,074.1$ \\
\hline $\begin{array}{l}\text { Upland hardwoods: } \\
\text { North delta. } \\
\text { South delta } \\
\text { North pine } \\
\text { Southeast and southwest pine }\end{array}$ & $\begin{array}{r}5.2 \\
54.6 \\
23.5\end{array}$ & $\begin{array}{l}18.4 \\
52.2 \\
30.0\end{array}$ & $\begin{array}{l}34.9 \\
76.3 \\
55.7\end{array}$ & $\begin{array}{r}7.0 \\
118.9 \\
61.7\end{array}$ & $\begin{array}{r}11.3 \\
140.7 \\
172.4\end{array}$ & 32.9 & $\begin{array}{r}.9 \\
1.6 \\
2.5\end{array}$ & $\begin{array}{r}77.7 \\
477.2 \\
380.0\end{array}$ \\
\hline Total & 83.3 & 100.6 & 166.9 & 187.6 & 324.4 & 67.1 & 5.0 & 934.9 \\
\hline $\begin{array}{l}\text { Bottom-land hardwoods: } \\
\text { North delta } \\
\text { South delta. } \\
\text { North pine. } \\
\text { Southeast and southwest pine }\end{array}$ & $\begin{array}{l}547.5 \\
228.8 \\
118.9 \\
179.9\end{array}$ & $\begin{array}{l}694.1 \\
481.0 \\
128.5 \\
330.1\end{array}$ & $\begin{array}{r}502.9 \\
1,114.8 \\
184.8 \\
218.0\end{array}$ & $\begin{array}{l}180.3 \\
222.6 \\
141.4 \\
138.3\end{array}$ & $\begin{array}{r}375.7 \\
1,108.6 \\
183.1 \\
184.8\end{array}$ & $\begin{array}{l}57.3 \\
46.2 \\
18.5 \\
13.6\end{array}$ & $\begin{array}{r}80.0 \\
140.6 \\
1.6 \\
5.4\end{array}$ & $\begin{array}{r}2,437.8 \\
3,342.6 \\
776.8 \\
1,070.1\end{array}$ \\
\hline Total & $1,075.1$ & $1,633.7$ & $2,020.5$ & 682.6 & $1,852.2$ & 135.6 & 227.6 & $7,627,3$ \\
\hline $\begin{array}{l}\text { All types: } \\
\text { North delta } \\
\text { South delta } \\
\text { North pine. } \\
\text { Southeast and southwest pine }\end{array}$ & $\begin{array}{l}547.5 \\
248.8 \\
234.6 \\
304.4\end{array}$ & $\begin{array}{l}695.8 \\
505.5 \\
266.7 \\
538.6\end{array}$ & $\begin{array}{r}513.8 \\
1,305.1 \\
1,290.2 \\
1,428.1\end{array}$ & $\begin{array}{r}186.2 \\
283.7 \\
1,034.7 \\
670.4\end{array}$ & $\begin{array}{r}382.4 \\
1,189.8 \\
864.5 \\
1,537.0\end{array}$ & $\begin{array}{r}59.0 \\
56.7 \\
100.4 \\
392.0\end{array}$ & $\begin{array}{r}81.7 \\
145.8 \\
35.3 \\
1,295.6\end{array}$ & $\begin{array}{l}2,466,4 \\
3,735.4 \\
3,826,4 \\
6,166,1\end{array}$ \\
\hline Total... & $1,335.3$ & $2,006.6$ & $4,537.2$ & $2,175.0$ & $3,973.7$ & 608,1 & $1,558,4$ & $16,194,3$ \\
\hline
\end{tabular}

TABLE 17.-Net board-foot valume, lumber tally, classified according to species group and survey unit, 1934-35

\begin{tabular}{|c|c|c|c|c|c|c|}
\hline Species group & North delta & South delta & North pine & $\begin{array}{l}\text { Southeast and } \\
\text { southwest pine }\end{array}$ & \multicolumn{2}{|c|}{ All units } \\
\hline $\begin{array}{l}\text { Pines: } \\
\quad \text { Longleat }\end{array}$ & $M$ board feet & $M$ board feet & \multirow[t]{2}{*}{$\begin{array}{r}M \text { board feet } \\
115,500\end{array}$} & \multirow{5}{*}{$\begin{array}{r}M \text { board feet } \\
1,934,300 \\
566,200 \\
1,166,300 \\
3,612,000 \\
180,500\end{array}$} & $\begin{array}{l}M \text { board feet } \\
2,049,800\end{array}$ & $\begin{array}{r}\text { Percent } \\
4.8\end{array}$ \\
\hline Slash & thes & & & & 566,200 & 1.4 \\
\hline Shortleat.- & \multirow{3}{*}{42,600} & 10,000 & $2,893,700$ & & $4,070,000$ & 9.6 \\
\hline Loblolly _.. & & 857,000 & $3,964,200$ & & $8,475,800$ & 20.0 \\
\hline Others.... & & 129,500 & 1,700 & & 311,700 & .7 \\
\hline Total pines. . & 42,600 & 996,500 & $6,975,100$ & $7,459,300$ & $15,473,500$ & 36.5 \\
\hline \multicolumn{7}{|l|}{ Hardwoods and cypress: } \\
\hline Sweetgum (redgum) & $1,383,900$ & 986,800 & $1,081,300$ & $1,259,800$ & $4,711,800$ & 11.1 \\
\hline Tupelos....... & 119,000 & $2,124,300$ & 428,300 & $1,157,700$ & $3,829,300$ & 9.0 \\
\hline Red oaks. & $1,893,000$ & 911,100 & 964,500 & $1,033,000$ & $4,801,600$ & 11.3 \\
\hline White oaks (high grade) & 109,600 & 156,700 & 808,400 & 644,500 & $1,719,200$ & 4.1 \\
\hline Post oak & $1,583,000$ & 371,400 & 406,500 & 201,600 & $2,562,500$ & 6.0 \\
\hline Cypress & 187,600 & 637,500 & 192,800 & 325,200 & $1,343,100$ & 3.2 \\
\hline Other hardwoods .. & $3,462,300$ & $2,303,700$ & 789,700 & $1,426,200$ & $7,981,900$ & 18.8 \\
\hline \multirow[t]{3}{*}{ Total hardwoods and cypress.. } & $8,738,400$ & $7,491,500$ & $4,671,500$ & $6,048,000$ & $26,949,400$ & 63.5 \\
\hline & $8,781,000$ & $8,488,000$ & $11,646,600$ & $13,507,300$ & $42,422,900$ & \\
\hline & Percent & Percent & Percent & Percent & & \\
\hline & 20.7 & 20.0 & 27.5 & 31.8 & & 100.0 \\
\hline
\end{tabular}


TABLE 18. - Net volume in cords of sound material ${ }^{1}$ in trees 5 inches d.b.h. and larger, by species group, qualib; class, and survey unit, 1937-35

Species group, quality class, and trec-diameter class (inchess)

North delta $\mid$ South delts $\mid$ North pine $\left|\begin{array}{c}\text { Southerst and } \\ \text { southwest pine }\end{array}\right| \quad$ All units

Longleaf and slash pines:

Sound trees of sawlog size:

$13.0+$

9.0 to 12.9

Top wood.

Sound trees 5.0 to 8.9

Cull trees.

Total.

Loblolly, shortleaf, and other pines:

Sound trees of sawlog size:

$13.0+\ldots$

9.0 to 12,9

Top wood .

Sound trees 5.0 to 8.9

Cull trees

Total..

All pines:

Sound trees of sawlog size:

$13.0+$

9.0 to 12.9

Top wood.

Sound trees 5.0 to 8.9

Cull trees.

Total.

Soft-textured hardwoods and cypress: 8

Sound trees 13.0+:

Sawlog material

Tops and limbs.

Sound trees 5.0 to 12.9

Cull trees.

Total

Firm-textured hardwoods: Sound trees 13.0+:

Sawlog material

Tops and limbs.

Sound trees 5.0 to 12.8

Cull trees.

Total.

All hardwood and cypress:

Sound trees 13.0+:

Sawlog material.

Tops and limbs.

Sound trees 5.0 to 12.9

Cull trees.

Total

All species:

Sound trees of sawlor size:

Sawlog material.

Tops and limbs

Sound trees undersawlog size

Cull trees.

All sound materißl

1 Sound volume in cull trees and in tons and limbs is only approximute.

- Includes 300,200 cords of longleat pine.

In the pine survey units, cypress was classed as of sawlog sige 11 90

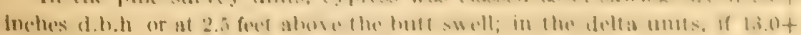
Inches d.h.h. or at 2.5 fert abose the butt wwell.

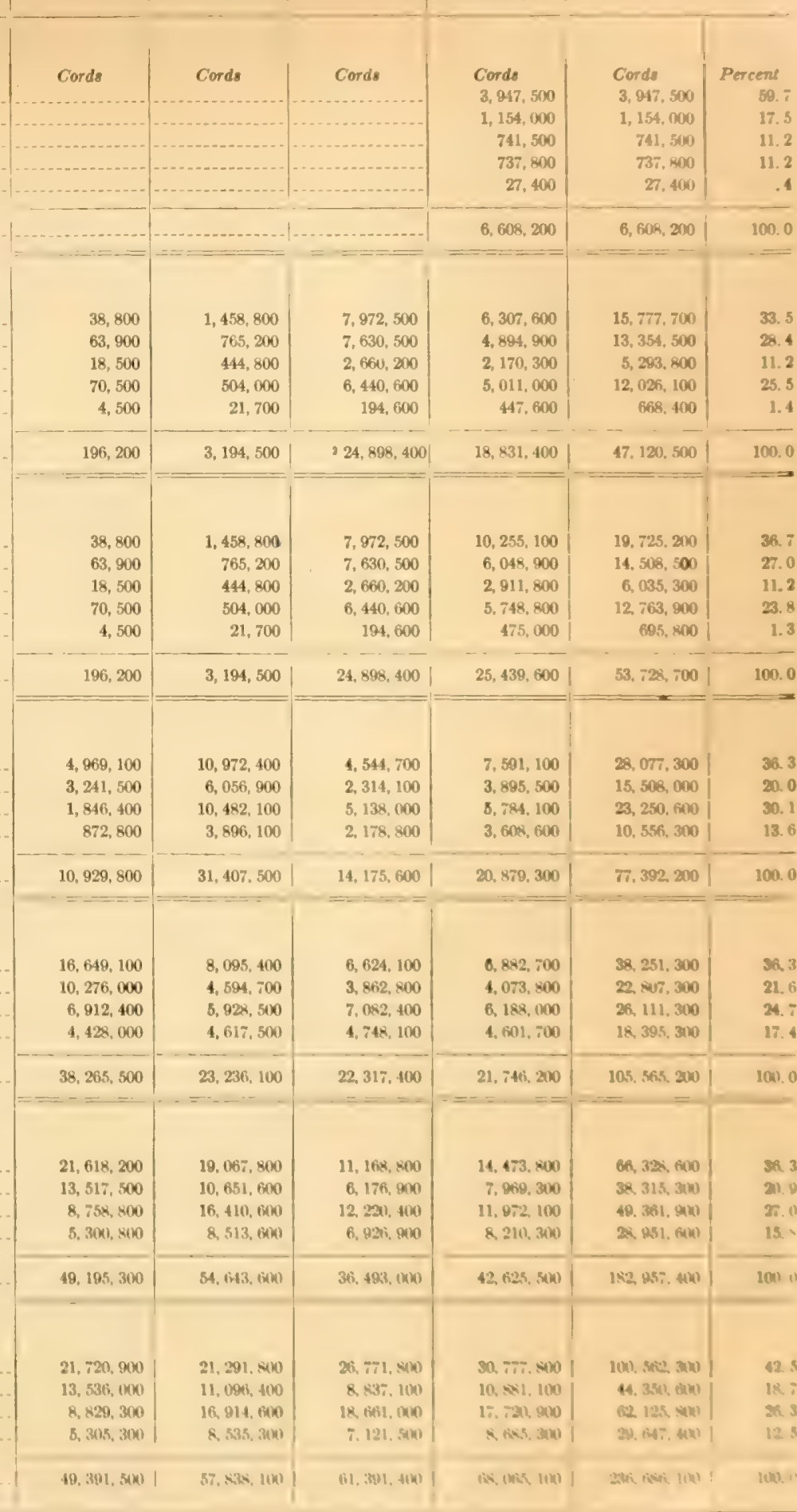

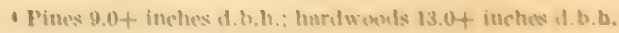

- Minituum sise 5.0 inches tl,b.h. 
TABLE 19.-Net cubic-foor volume (inside bark) of sound rood, ' by species group, quality class, and suriey unit, 193t-35

\begin{tabular}{|c|c|c|c|c|c|c|}
\hline Species group and quality class & North delta & South delta & North pine & $\begin{array}{l}\text { Southeast and } \\
\text { soutbwest pine }\end{array}$ & \multicolumn{2}{|c|}{ All units } \\
\hline \multicolumn{7}{|l|}{ Pines: } \\
\hline Sound trees of sawlog size: & 1,000 cubic feet & 1,000 cubic feet & 1,000 cubic feet & 1,000 cubic feet & 1,000 cubic feet & Percent \\
\hline sawlog material .. $\quad \ldots$. & 7,680 & 170,440 & $1,209,770$ & $1,259,490$ & $2,647,380$ & 64.8 \\
\hline Top wond . $\quad \ldots \ldots \ldots$ & 1,190 & 31,350 & 205,620 & 223,020 & 461,180 & 11.3 \\
\hline Sound trees under sawlog size $\quad \ldots \ldots \ldots \ldots$ & 4,970 & 33,650 & 470,500 & 415,550 & 924,670 & 22.6 \\
\hline Cull trees . . . . & 300 & 1,630 & 14,850 & 35,830 & 52,610 & 1.3 \\
\hline Total ........... & 14,140 & 237,070 & $1,900,740$ & $1,933,890$ & $4,085,840$ & 100,0 \\
\hline $\begin{array}{l}\text { Soft-textured hardwoods }{ }^{2} \text { and eypress: } \\
\text { Sound trees of sawlog size: }\end{array}$ & & & & & & \\
\hline Saw log material $\ldots \ldots \ldots \ldots \ldots$ & 355,820 & 768,090 & 315,030 & 528,790 & $1,967,730$ & 38.3 \\
\hline 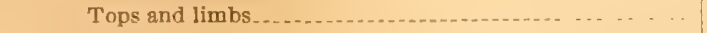 & $20 \overline{7}, 790$ & 384.240 & 148,350 & 248,740 & 989,120 & 19.2 \\
\hline Sound trees under sawlog size $\ldots \ldots \ldots \ldots \ldots$ & 113,860 & 676,040 & $32 \pi, 660$ & 367,450 & $1,485,010$ & 28.9 \\
\hline 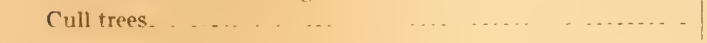 & 58.500 & 257,340 & 143,370 & 237,880 & 697,090 & 13. 6 \\
\hline Total & 735,970 & $2,085,710$ & 934,410 & $1,382,860$ & $5,138,950$ & 100. 0 \\
\hline $\begin{array}{l}\text { Firm-textured hardwoods: } 2 \\
\text { Sound trees of sawlog size: }\end{array}$ & & & & & & \\
\hline Sawlog material... $\ldots \ldots \ldots \ldots$ & $1,156,850$ & 558,040 & 456,030 & 474,850 & $2,645,770$ & 38.8 \\
\hline Tops and limbs $\ldots \ldots$ & 658,720 & 287,810 & 245,420 & 258,160 & $1,450,110$ & 20.0 \\
\hline Sound trees under sawlog size $\ldots \ldots \ldots$ & 448,130 & 370,800 & 449,760 & 392,020 & $1,660,710$ & 23.8 \\
\hline Cull trees. & 296,500 & 303,900 & 310,630 & 301,730 & $1,212,760$ & 17.4 \\
\hline Total $\ldots \ldots \ldots$ & $2,560,200$ & $1,520,550$ & $1,461,840$ & $1,426,760$ & $6,969,350$ & 100.0 \\
\hline $\begin{array}{l}\text { Total hardwoods and cypress: } \\
\text { Sound trees of sawlog size: }\end{array}$ & & & & & & \\
\hline Sawlog material .................. & $1,512,670$ & $1,326,130$ & 771,060 & $1,003,640$ & $4,613,500$ & 38. 1 \\
\hline 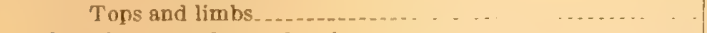 & 866,510 & 672,050 & 393,770 & 506,900 & $2,439,230$ & 20.1 \\
\hline Sound trees under sawlog size & 561,990 & $1,046,840$ & $77 \%, 420$ & 759,470 & $3,145,720$ & 26.0 \\
\hline Cull trees & 355,000 & 561.240 & 454,000 & 539,610 & $1,909,850$ & 15.8 \\
\hline Total & $3,296,170$ & $3,606,260$ & $2,396,250$ & $2,809,620$ & $12,108,300$ & 100. 0 \\
\hline $\begin{array}{l}\text { Total, all species: } \\
\text { Sound trees of sawlog size: }\end{array}$ & & & & & & \\
\hline 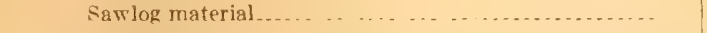 & $1,520,350$ & $1,496,570$ & $1,980,830$ & $2,263,130$ & $7,260,880$ & 44. 9 \\
\hline Tops and limbs ........ $\ldots \ldots \ldots \ldots$ & 867,700 & 703,400 & 599,390 & 729,920 & $2,900,410$ & 17.9 \\
\hline Sound trees under saw $\log$ size $\quad \ldots \ldots \ldots . . . . . . .$. & 566,960 & $1,080,490$ & $1,247,920$ & $1,175,020$ & $4,070,390$ & 25,1 \\
\hline Cull trees....$\ldots \ldots \ldots \ldots \ldots \ldots \ldots$ & 355,300 & 562,870 & 468,850 & 575,440 & $1,962,460$ & 12,1 \\
\hline & $3,310,310$ & $3,843,330$ & $4,296,990$ & $4,743,510$ & $16,194,140$ & $+\infty-\infty$ \\
\hline All sound wnod. . .................. & $\begin{array}{l}\text { Percent } \\
20.4\end{array}$ & $\begin{array}{l}\text { Percent } \\
23.7\end{array}$ & $\begin{array}{l}\text { Percent } \\
26.6\end{array}$ & $\begin{array}{l}\text { Percent } \\
29.3\end{array}$ & & 100.0 \\
\hline
\end{tabular}

1 Sound volume in culls and in tops and limbs is only approximate.

2 For list of species included, see p. 6.

TABI.E. 20.-Tonnage of longleaf pine stumps removable by blasting in the south pine units, classified according to number per acre and forest condition, 1934-35

Stumps per acre (number)

5 or less

6 to 13.

14 to 25 .

26 or more

Total

\begin{tabular}{|c|c|c|c|c|c|c|}
\hline \multirow{3}{*}{$\begin{array}{l}\text { Old growth } \\
1,000 \text { tons }\end{array}$} & \multicolumn{3}{|c|}{ Second growth } & \multirow{3}{*}{ Clear-cut } & \multirow{2}{*}{\multicolumn{2}{|c|}{ All conditions }} \\
\hline & \multirow{2}{*}{ Sawlog size } & \multirow{2}{*}{$\begin{array}{c}\begin{array}{c}\text { Under sawlog } \\
\text { size }\end{array} \\
1,000 \text { tons }\end{array}$} & \multirow{2}{*}{ Reproduction } & & & \\
\hline & & & & & 1,000 tons & Percent \\
\hline 8 & 16 & 25 & 11 & 44 & 104 & 1.4 \\
\hline 50 & 102 & 281 & 83 & 365 & 881 & 11.8 \\
\hline 116 & 147 & 479 & 231 & 1,280 & 2,253 & 30.2 \\
\hline 113 & 159 & 541 & 375 & 3,044 & 4,232 & 56.6 \\
\hline 287 & 424 & 1,326 & 700 & 4, 733 & 7,470 & \\
\hline Percent & Percent & Percent & Percent & Percent & & \\
\hline 3.8 & 5.7 & 17.7 & 9.4 & 63.4 & & 100.0 \\
\hline
\end{tabular}


T +BL.F. 21.--Pole and pile ressurces, \&y tree-diameter class and length of product, 1937-35

\begin{tabular}{|c|c|c|c|c|c|c|c|c|c|}
\hline $\begin{array}{l}\text { Survey unit and trew- } \\
\text { diameter class finelhes }\end{array}$ & 21) feet & 25 teet & 34) leet & 35 feret & Iut faret & 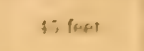 & $\begin{array}{l}\text { 50) foet and } \\
\text { river }\end{array}$ & \multicolumn{2}{|c|}{$1 \ldots \ldots$} \\
\hline North pine: & 1,for pieces & $\begin{array}{l}1,600 \text { pieces } \\
1,11,-3\end{array}$ & 1.trefs pitces & 1.prif pieces - & 1.tWh pieres & $1, x+1)$ fiteces & 1. Whe pureses & $\therefore \cos$ ine & Pa...... \\
\hline $\begin{array}{l}7 .(1-8.9 . \\
\text { 8. } 10-10.9 \ldots\end{array}$ & $\begin{array}{l}\text { 3. } \times 22 \\
1, \times 32\end{array}$ & $\begin{array}{l}1,11 ; .3 \\
1.2 * 3\end{array}$ & 1. 111.5 & $4: y$ & 25 & I'*. & 32 & 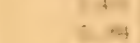 & 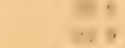 \\
\hline $11.11-12.9 \ldots \ldots$ & $6: 23$ & $i+i$ & $\omega 2$ & $4: 2$ & 241 & $i: \infty$ & 144 & 3. 2 ; & $=4$ \\
\hline $13.11-14.9 \ldots \ldots \ldots$. & 122 & $2 \times 9$ & ; & 219 & $15 \%$ & 102 & $\therefore=$ & 1. $4=7$ & 6. \\
\hline $15016.9 \ldots \ldots$ & 11) & 4 & 233 & 9.5 & .1 & 42 & it: & $\because 2$ & 3. \\
\hline $17.11-1 \times .9$ & ... . & 1 in & 1113 & $3 n$ & 2 & 1.. & 23 & $\therefore 2$ & $: ;$ \\
\hline Tortal. & 6., $36: 9$ & 3. 171 & 3.371 & 1. 34 & -33 & $\cdots 2$ & $\therefore t^{-}$ & 1.... & 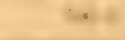 \\
\hline sonth pine: & & & & & & & & & \\
\hline 7.1t $8.9 \ldots \ldots$ & 2. $74: 2$ & $\sin 3$ & 123 & 2i) & . & . & ....... & 3. $\cdots$ & 21 \\
\hline $9,11-110,9 \ldots \ldots \ldots \ldots$ & 1. $\times 45$ & $(i)$ & $v 1+i$ & 19.5 & jent & 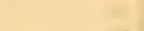 & $\ldots$ & 3. $\cdots$ & $x=9$ \\
\hline $11.11-12.9 \ldots \ldots \ldots \ldots$ & $4: 3$ & 6.5\% & wati & 243 & 121 & $\$ 3$ & 31 & $2 \cdot: 4$ & $\therefore=$ \\
\hline $13 .(1-14.9 \ldots$ & 3.59 & 34.5 & 345 & 1.11 & ari & 3t1 & 58 & $2 .+\div$ & $1:$ \\
\hline 15. $11-16-9$. & 111 & $1: 3$ & $1 \% 2$ & +1 & 45 & 31 & 35 & wi: & +2 \\
\hline $17.1+14.9$. & 2.5 & 51 & $\therefore$ & 33 & in & 1"1 & 23 & $2:=$ & \\
\hline Total & ก., 127 & 2. $7+t_{i 5}$ & 2,72 & $\because 23$ & 434 & $\therefore 4$ & $1+i$ & $: 2 \cdots:$ & 100 \\
\hline All gine: & & & & & & & & & \\
\hline $7.01-\times 9-\ldots$ & 6,524 & 1. 7 ini & 912 & $16 \%$ & & & & 9. 20 & $x+\cdots$ \\
\hline $9 .(1-10.9, \quad \ldots \ldots$ & 3. 729 & 2. 139 & 1,911 & $\mathrm{i} i \mathrm{it}$ & 421 & IE*i: & .32 & 9. $1 \%$ & 3. 2 \\
\hline $11.1-12.9$ & 1.616 & 1. 403 & 1. sile & biri.5 & 362 & $2 \div 9$ & 155 & c... & $\because 1$ \\
\hline 13. $0-14.9$ & 401 & 634 & 592 & 3.0 & 231 & 152 & $\operatorname{lin}$ & $2 . \cdots$ & ite a \\
\hline $15.0-16.9 \ldots$ & 121 & 237 & 407 & 176 & 106 & 73 & $\$$ & 1. 365 & $4:$ \\
\hline $17,0-18.9$ & 25 & $6:$ & 150 & $\because 1$ & 47 & $2 i$ & $4 i$ & if & 1. \\
\hline Tot 1 & $\begin{array}{c}12.4(4) \\
\text { Percent } \\
4301 \\
\end{array}$ & $\begin{array}{c}\text { 6, } 236 \\
\text { Percent } \\
21.4 \\
\end{array}$ & $\begin{array}{c}5,898 \\
\text { Percent } \\
200.3 \\
\end{array}$ & $\begin{array}{r}\text { 2, } 0633 \\
\text { Percent } \\
\text { 7. } 1 \\
\end{array}$ & $\begin{array}{r}1,167 \\
\text { Percent } \\
4.0 \\
\end{array}$ & $\begin{array}{r}\text { Pereent } \\
\text { 2.5 } \\
\end{array}$ & $\begin{array}{r}\text { Percent } \\
1 \text { - }\end{array}$ & 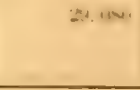 & $\therefore$ 1) 0 \\
\hline
\end{tabular}

TABLE 22.-Employment in forest industries, 1937

[Thousands of 8-hour man-days; i. e. 000 omitted]

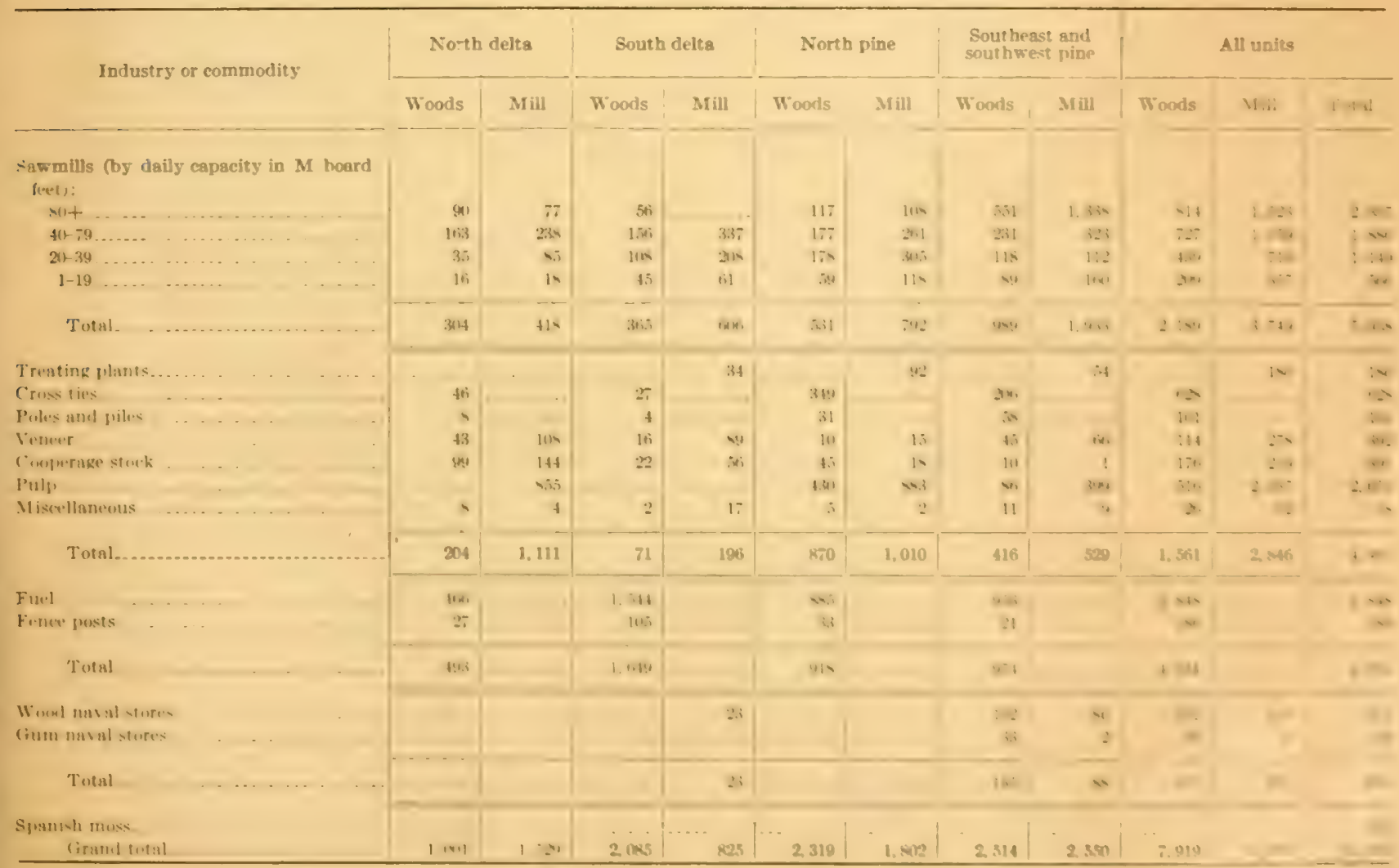


TABLE 23.-Commodity drain from sound trees, by survey unit and species group, 1937

FROM SAW-TIMBER GROWING STOCK (LUMBER TALLY)

\begin{tabular}{|c|c|c|c|c|c|c|c|c|c|c|c|c|c|c|c|}
\hline \multirow[b]{2}{*}{ Item } & \multicolumn{3}{|c|}{ North delta } & \multicolumn{3}{|c|}{ South delta } & \multicolumn{3}{|c|}{ North pine } & \multicolumn{3}{|c|}{$\begin{array}{l}\text { Southeast southwest } \\
\text { pine }\end{array}$} & \multicolumn{3}{|c|}{ All units } \\
\hline & Pine & $\begin{array}{c}\text { Hard- } \\
\text { woods } \\
\text { and } \\
\text { cypress }\end{array}$ & Total & Pine & $\begin{array}{c}\text { Hard- } \\
\text { woods } \\
\text { and } \\
\text { cypress }\end{array}$ & Total & Pine & $\begin{array}{c}\text { Hard- } \\
\text { woods } \\
\text { and } \\
\text { cypress }\end{array}$ & Total & Pine & $\begin{array}{c}\text { Hard- } \\
\text { woods } \\
\text { and } \\
\text { cypress }\end{array}$ & Total & Pine & $\begin{array}{l}\text { Hard- } \\
\text { woods } \\
\text { and } \\
\text { eypress }\end{array}$ & Total \\
\hline Lumber... & $\begin{array}{c}\text { M board } \\
\text { feet } \\
1,300\end{array}$ & $\begin{array}{c}\text { M board } \\
\text { feet } \\
199,900\end{array}$ & $\begin{array}{c}\text { M board } \\
\text { feet } \\
201,200\end{array}$ & $\begin{array}{c}\text { Mboard } \\
\text { feet } \\
32,000\end{array}$ & $\begin{array}{c}\text { M board } \\
\text { feet } \\
210,100\end{array}$ & $\begin{array}{c}M \text { board } \\
\text { feet } \\
242,100\end{array}$ & $\left|\begin{array}{c}\text { M board } \\
\text { feet } \\
297,200\end{array}\right|$ & $\begin{array}{c}\text { Mboard } \\
\text { feet } \\
84,300\end{array}$ & $\begin{array}{c}\text { M board } \\
\text { feet } \\
381,500\end{array}$ & $\begin{array}{c}M \text { board } \\
\text { feet } \\
516,800\end{array}$ & $\begin{array}{c}M \text { board } \\
\text { feet } \\
175,300\end{array}$ & $\begin{array}{c}M \text { board } \\
\text { feet } \\
692,100\end{array}$ & $\begin{array}{c}\text { Mboard } \\
\text { feet } \\
847,300\end{array}$ & $\begin{array}{c}M \text { board } \\
\text { feet } \\
669,600\end{array}$ & $\begin{array}{c}M \text { board } \\
\text { feet } \\
1,516,900\end{array}$ \\
\hline Cross ties ....... & 2,900 & 13,700 & 16,600 & 3,400 & 4,400 & 7,800 & 66,300 & 29,500 & 95,800 & 46,000 & 9,900 & 55,900 & 118,600 & 57,500 & 176,100 \\
\hline Poles and piles... & & 4,400 & 4,400 & -1 & 1,500 & 1,500 & 7,500 & 700 & 8,200 & 19,100 & 1,200 & 20,300 & 26,600 & 7,800 & 34,400 \\
\hline Veneer........... & & 25,300 & 25,300 & & 10,900 & 10,900 & 100 & 5,600 & 5,700 & 4,800 & 16,700 & 21,500 & 4,900 & 58,500 & 63,400 \\
\hline Cooperage & & 44,400 & 44,400 & & 11,600 & 11,600 & & 21,400 & 21,400 & 100 & 4,300 & 4,400 & 100 & 81,700 & 81,800 \\
\hline Pulpwood . . & & & & & & & 80,500 & & 80,500 & 16,900 & & 16,900 & 97,400 & & 97,400 \\
\hline Miscellaneous.. & & 1,100 & 1,100 & 1 & 500 & 500 & 100 & 300 & 400 & -....-- & 2,300 & 2,300 & 100 & 4,200 & 4,300 \\
\hline Fuel wood..... & & 21,800 & 21,800 & 1,400 & 104,400 & 105,800 & 80,700 & 9,400 & 90,100 & 43,000 & 13,800 & 56,800 & 125,100 & 149,400 & 274,500 \\
\hline Fence posts & & 3,100 & 3,100 & --_-- | & 10,200 & 10,200 & 1,300 & 300 & 1,600 & 800 & 200 & 1,000 & 2,100 & 13,800 & 15,900 \\
\hline Miscellaneous farm use. & & 1,200 & 1,200 & & 2,200 & 2,200 & 4,200 & 400 & 4,600 & 3,400 & 300 & 3,700 & 7,600 & 4,100 & 11,700 \\
\hline Land clearing.......... & & 32,800 & 32,800 & 2,000 & 13,400 & 15,400 & 2,000 & 4,100 & 6,100 & 900 & 1,200 & 2,100 & 4,900 & 51,500 & 56,400 \\
\hline Total. & 4,200 & $347,700 \mid$ & $351,900 \mid$ & 38,800 & \begin{tabular}{l|l}
369,200 \\
\end{tabular} & 408,000 & 539,900 & 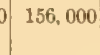 & 695,900 & 651.800 & 225,200 & 877,000 & $1,234,700$ & $1,098,100$ & $2,332,800$ \\
\hline
\end{tabular}

FROM UNDER-SAWLOG-SIZE TREES AND TOPS OF SAWLOG-SIZE PINES (INCLUDING BARKi

\begin{tabular}{|c|c|c|c|c|c|c|c|c|c|c|c|c|c|c|c|}
\hline Lumber.... & $\begin{array}{r}\text { Cords } \\
400\end{array}$ & $\begin{array}{c}\text { Cords } \\
22,800\end{array}$ & $\begin{array}{c}\text { Cords } \\
23,200\end{array}$ & $\begin{array}{l}\text { Cords } \\
12,400\end{array}$ & $\begin{array}{c}\text { Cords } \\
21,300\end{array}$ & $\begin{array}{c}\text { Cords } \\
33,700\end{array}$ & $\begin{array}{c}\text { Cords } \\
108,800\end{array}$ & Cords & $\begin{array}{c}\text { Cords } \\
108,800\end{array}$ & $\begin{array}{c}\text { Cords } \\
184,900\end{array}$ & $\begin{array}{r}\text { Cords } \\
1,300\end{array}$ & $\begin{array}{c}\text { Cords } \\
186,200\end{array}$ & $\begin{array}{l}\text { Cords } \\
306,500\end{array}$ & $\begin{array}{l}\text { Cords } \\
45,400\end{array}$ & $\begin{array}{l}\text { Cords } \\
351,900\end{array}$ \\
\hline Cross ties... & 900 & 4,700 & 5,600 & 1,400 & 1,100 & 2,500 & 26,600 & 300 & 26,900 & 19,500 & 4,600 & 24,100 & 48,400 & 10,700 & 59,100 \\
\hline Poles and piles_ & & & & & & & 10,100 & & 10,100 & 9,800 & & 9,800 & 19,900 & & 19,900 \\
\hline Veneer............ & & 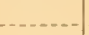 & & & & $\ldots$ & $\ldots$ & & $\ldots$ & 1,700 & & 1,700 & 1,700 & & 1,700 \\
\hline Cooperage.- & & 10,300 & 10,300 & ....... & 500 & 500 & $\ldots$ & & & 500 & tert & 500 & 500 & 10,800 & 11,300 \\
\hline Pulpwood.. & & $\ldots . . . .$. & ........ & & $\ldots$ & $\ldots$ & 137,200 & 4,600 & 141,800 & 29,000 & 100 & 29,100 & 166,200 & 4,700 & 170,900 \\
\hline Miscellaneous.- & & 200 & 200 & $\cos -\theta$ & 1,000 & 1,000 & 500 & & 500 & & 2,400 & 2,400 & 500 & 3,600 & 4,100 \\
\hline Fuel wood ..... & & 86,400 & 86,400 & 1,200 & 167,700 & 168,900 & 150,600 & 17,900 & 168,500 & 111,700 & 23,300 & 135,000 & 263,500 & 295,300 & 558,800 \\
\hline Fence posts & & 3,300 & 3,300 & 400 & 9,500 & 9,900 & 4,000 & 300 & 4,300 & 6,600 & 400 & 7,000 & 11,000 & 13,500 & 24,500 \\
\hline Miscellaneous farm use & & 3,000 & 3,000 & $\ldots$ & 5,500 & 5,500 & 11,200 & 800 & 12,000 & 8,900 & 600 & 9,500 & 20,100 & 9,990 & 30,000 \\
\hline Land clearing & & 76,400 & 76,400 & 1,300 & 12,500 & 13,800 & 15,900 & 43,000 & 58,900 & 4,700 & 8,800 & 13,500 & 21,900 & 140,700 & 162,600 \\
\hline Total & 1,300 & 207,100 & 208,400 & 16,700 & 219,100 & 235,800 & 464,900 & 66,900 & 531,800 & 377,300 & 41,500 & 418,800 & $860,2 \omega 0$ & 534,600 & $1,394,800$ \\
\hline
\end{tabular}

FROM ALL GROWING STOCK (NOT INCLUDING BARK)

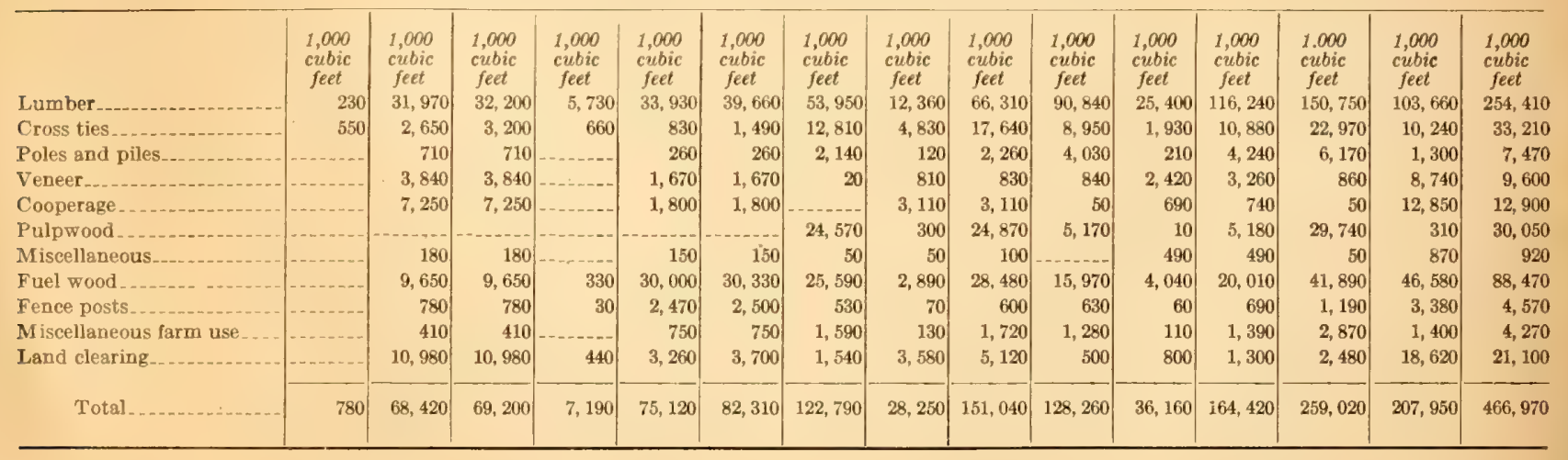


TABI.F. 24,--Change in growing stock in board feet, lumber tally, by species group and sur:ey unit, in I", 27

\section{Item}

1'ines:

Growing stock Jan. 1, 1937

(irowth...--

Mortality - -

Net increment.

Commodity drain

Net change in growing stock.

Growing stock Jan. 1, 1933.

Hardwoods and cyjuress:

Growing stock Jan. 1, 1937.

\section{firowth}

Murtality

Net increment

Commodity drain

Net change in growing stock

Orowing stock Jan, 1, 1938

All species:

Growing stock Jan, 1, 1937.

Growth.

Mortality

Net increment

Commodity drain

Net change in growing stock.

Growing stock Jan, 1, 1938

\begin{tabular}{|c|c|c|c|c|}
\hline North delta & South delta & North pine & $\begin{array}{l}\text { Southrast and } \\
\text { southwest pine }\end{array}$ & All un:" \\
\hline $\begin{array}{r}\text { M board feet } \\
39,600\end{array}$ & $\begin{array}{r}M \text { board feet } \\
1,059,100\end{array}$ & $\begin{array}{l}M \text { board feet } \\
6,892,700\end{array}$ & $\begin{array}{r}M \text { boord feet } \\
7,185,400\end{array}$ & $\begin{array}{l}M \text { board feet } \\
\qquad 15,17 f_{4}, \text { vilo }\end{array}$ \\
\hline$=-\ldots=-1$ & 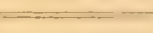 & $-=0,+\cdots$ & $=--$ & - \\
\hline 5,000 & 89,000 & 505,300 & 566,2010 & 1. 16.5, 5(1) \\
\hline 1,800 & 10,600 & 54,300 & 74,3010 & 143. (Juif) \\
\hline 3,200 & 78.400 & 451.000 & 491.900 & $1,024,5(n)$ \\
\hline 4,200 & 38.800 & 539.900 & 651,800 & $1,234,700$ \\
\hline$-1,000$ & +39.600 & $-88,900$ & -159.900 & $-210.3 \mathrm{mi}$ \\
\hline$--\quad-$ & $-\ldots \ldots$ & $=--=$ & 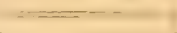 & $1-x_{-10}$ \\
\hline 38,600 & $1,098,700$ & $6,803.800$ & $\quad 7,025,500$ & 14, 9rifi, fins \\
\hline 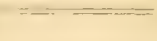 & $=$ & $=$ & & 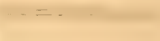 \\
\hline $8,350,800$ & $7,442,400$ & 4. 768,700 & $6,021,200$ & $25,3 \times 3.1 \mathrm{~cm}$ \\
\hline 308200 & - & & & $\bar{F}=-$ \\
\hline 308,300 & 409. 700 & 256.600 & 276.400 & 1, 251, nory \\
\hline 119,100 & 133,200 & 52.200 & 48,000 & 353,500 \\
\hline 189,200 & 276,500 & 204,400 & $22 \%, 400$ & 897.500 \\
\hline 347.700 & 369,200 & 156,000 & 225.200 & $1,096,100$ \\
\hline$-158,500$ & $-92,700$ & $+48,400$ & +2200 & $+200,600$ \\
\hline $8,192,300$ & $7,349,700$ & $4,81 \%, 100$ & $6,023,400$ & $26,3 \times 2,500$ \\
\hline$\Longrightarrow==$ & $=$ & $=-1=-1$ & $-\underline{-}=$ & $-=2 \quad=$ \\
\hline $8,390,400$ & $8,501,500$ & $11,661,400$ & $13,206,600$ & 41. 759.900 \\
\hline$==-=--$ & & $-=-$ & 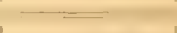 & $=\quad=$ \\
\hline 313,300 & 498,700 & 761.900 & 842.600 & $2,416,500$ \\
\hline 120,900 & 143,800 & 106.500 & 123.300 & 494. 500 \\
\hline 192,400 & 354,900 & 655,400 & 719,300 & $1,922,000$ \\
\hline 351,900 & 408,000 & 695.900 & $8 \% \div, 000$ & 2.332 .44 \\
\hline-159.500 & -53.100 & $-40,500$ & -157.700 & $-410, \times 00$ \\
\hline $8,230,900$ & $8,448,400$ & $11,620,900$ & $13,098,900$ & 41, 349,100 \\
\hline
\end{tabular}

TABLE. 25.-Change in grawing stock in cords (including bark), by species group and surey unit, in $70:-$

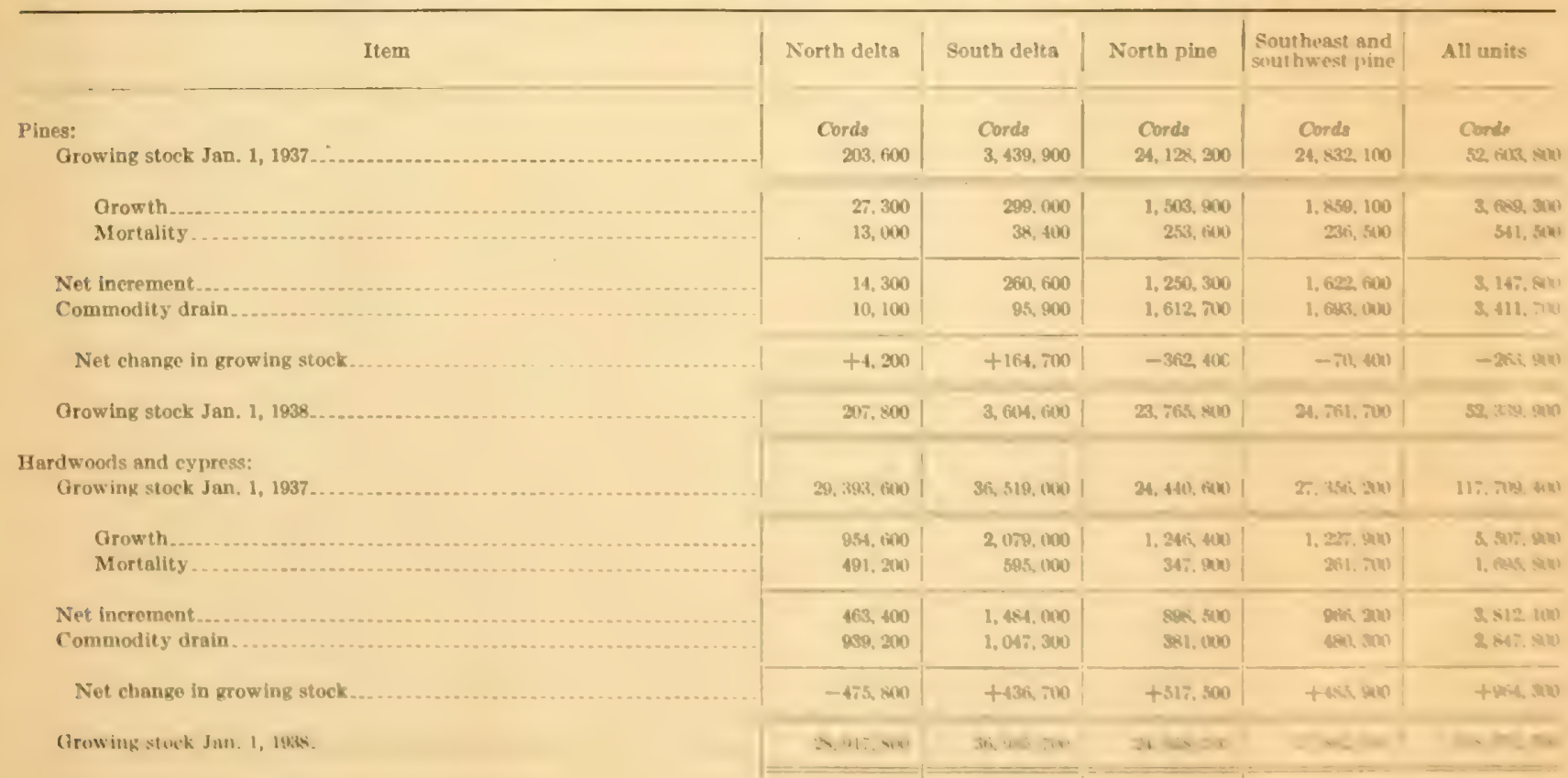


TABLE 25.-Change in growing stock in cords (including bark), by species group and survey unit, in 1937-Continued Item

All species:

Growing stock Jan. 1, 1937

Growth

Mortality

Net increment...

Commodity drain

Net change in growing stock.

Growing stock Jan. 1, 1938

\begin{tabular}{|c|c|c|c|c|}
\hline North delta & South delts & North pine & $\begin{array}{l}\text { Southeast and } \\
\text { southwest pine }\end{array}$ & All units \\
\hline $\begin{array}{l}\text { Cords } \\
29,597,200\end{array}$ & $\begin{array}{l}\text { Cords } \\
39,958,900\end{array}$ & $\begin{array}{l}\text { Cords } \\
48,568,800\end{array}$ & $\begin{array}{l}\text { Cords } \\
52,188,300\end{array}$ & $\begin{array}{l}\text { Cotds } \\
170,313,200\end{array}$ \\
\hline $\begin{array}{l}981,900 \\
504,200\end{array}$ & $\begin{array}{r}2,378,000 \\
633,400\end{array}$ & $\begin{array}{r}2,750,300 \\
601,500\end{array}$ & $\begin{array}{r}3,087,000 \\
498,200\end{array}$ & $\begin{array}{l}9,197,200 \\
2,237,300\end{array}$ \\
\hline $\begin{array}{l}477,700 \\
949,300\end{array}$ & $\begin{array}{l}1,744,600 \\
1,143,200\end{array}$ & $\begin{array}{l}2,148,800 \\
1,993,700\end{array}$ & $\begin{array}{l}2,588,800 \\
2,173,300\end{array}$ & $\begin{array}{l}6,959,900 \\
6,259,500\end{array}$ \\
\hline$-471,600$ & $+601,400$ & $+155,100$ & $+415,500$ & $+700,400$ \\
\hline $29,125,600$ & $40,560,300$ & $48,723,900$ & $52,603,800$ & $171,013,600$ \\
\hline
\end{tabular}

TABLE 26.-Change in growing stock in cubic feet (inside bark), by species group and survey unit, in 1937

\section{Item}

Pines:

Growing stock Jan. 1, 1937

Growth

Mortality

Net increment

Commodity drain

Net change in growing stock

Growing stock Jan. 1, 1938

Hardwoods and cypress:

Growing stock Jan, 1, 1937

Grow th

Mortality

Net increment...

Commodity drain

Net change in growing stock

Growing stock Jan. 1, 1937

All species:

Growing stock Jan. 1, 1937

Growth...

Mortality

Net increment

Commodity drain

Net change in growing stock

Growing stock Jan. 1, 1938

\begin{tabular}{|c|c|}
\hline North delta & South delta \\
\hline $\begin{array}{r}\text { M cubic feet } \\
14,700\end{array}$ & $\begin{array}{r}M \text { cubic feet } \\
255,260\end{array}$ \\
\hline 2,030 & 22,260 \\
\hline 940 & 2,850 \\
\hline 1,090 & 19,410 \\
\hline 780 & 7.190 \\
\hline+310 & $+12,220$ \\
\hline 15,010 & 267,480 \\
\hline $2,007,500$ & $2,442,360$ \\
\hline$=-=$ & $=-C=$ \\
\hline 69,780 & 143,590 \\
\hline 33,540 & 39,610 \\
\hline 36,240 & 103,980 \\
\hline 68,420 & 75,120 \\
\hline$-32,460$ & $+28,860$ \\
\hline $1,975,040$ & $2,471,220$ \\
\hline $2,022,200$ & $2,697,620$ \\
\hline 71,810 & 165,850 \\
\hline 34,480 & 42,460 \\
\hline 37,330 & 123,390 \\
\hline 69,200 & 82,310 \\
\hline$-32,150$ & $+41,080$ \\
\hline $1,990,050$ & $2,738,700$ \\
\hline
\end{tabular}

\begin{tabular}{|c|c|c|}
\hline North pine & $\begin{array}{l}\text { Southeast and } \\
\text { southwest pine }\end{array}$ & All units \\
\hline $\begin{array}{r}M \text { cubic feet } \\
1,841,970\end{array}$ & $\begin{array}{r}M \text { cubic feet } \\
1,886,160\end{array}$ & $\begin{array}{l}M \text { cubic feet } \\
\quad 3,998,090\end{array}$ \\
\hline 114,480 & 140,810 & 279,580 \\
\hline 19,360 & 17,950 & 41,100 \\
\hline 95,120 & 122,860 & 238,480 \\
\hline 122,790 & 128,260 & 259,020 \\
\hline$-27,670$ & $-5,400$ & $-20,540$ \\
\hline $1,814,300$ & $1,880,760$ & $3,977,550$ \\
\hline $1,614,590$ & $1,818,360$ & $7,882,810$ \\
\hline 85.190 & $==$ & \\
\hline $\begin{array}{l}85,420 \\
22,980\end{array}$ & $\begin{array}{l}85,730 \\
17,390\end{array}$ & $\begin{array}{l}384,520 \\
113,520\end{array}$ \\
\hline 62,440 & 68,340 & 271,000 \\
\hline 28,250 & 36,160 & 207,950 \\
\hline$+34,190$ & $+32,180$ & $+62,770$ \\
\hline $1,648,780$ & $1,850,540$ & $7,945,580$ \\
\hline $3,456,560$ & $3,704,520$ & $11,880,900$ \\
\hline$==$ & $\Rightarrow=-C=-$ & $=-5$ \\
\hline 199,900 & 226,540 & 664,100 \\
\hline 42,340 & 35,340 & 154,620 \\
\hline 157,560 & $191,20 \mathrm{u}$ & 509,480 \\
\hline 151,040 & 164,420 & 467,250 \\
\hline$+6,520$ & $+26,780$ & $+42,230$ \\
\hline $3,463,080$ & $3,731,300$ & $11,923,130$ \\
\hline
\end{tabular}




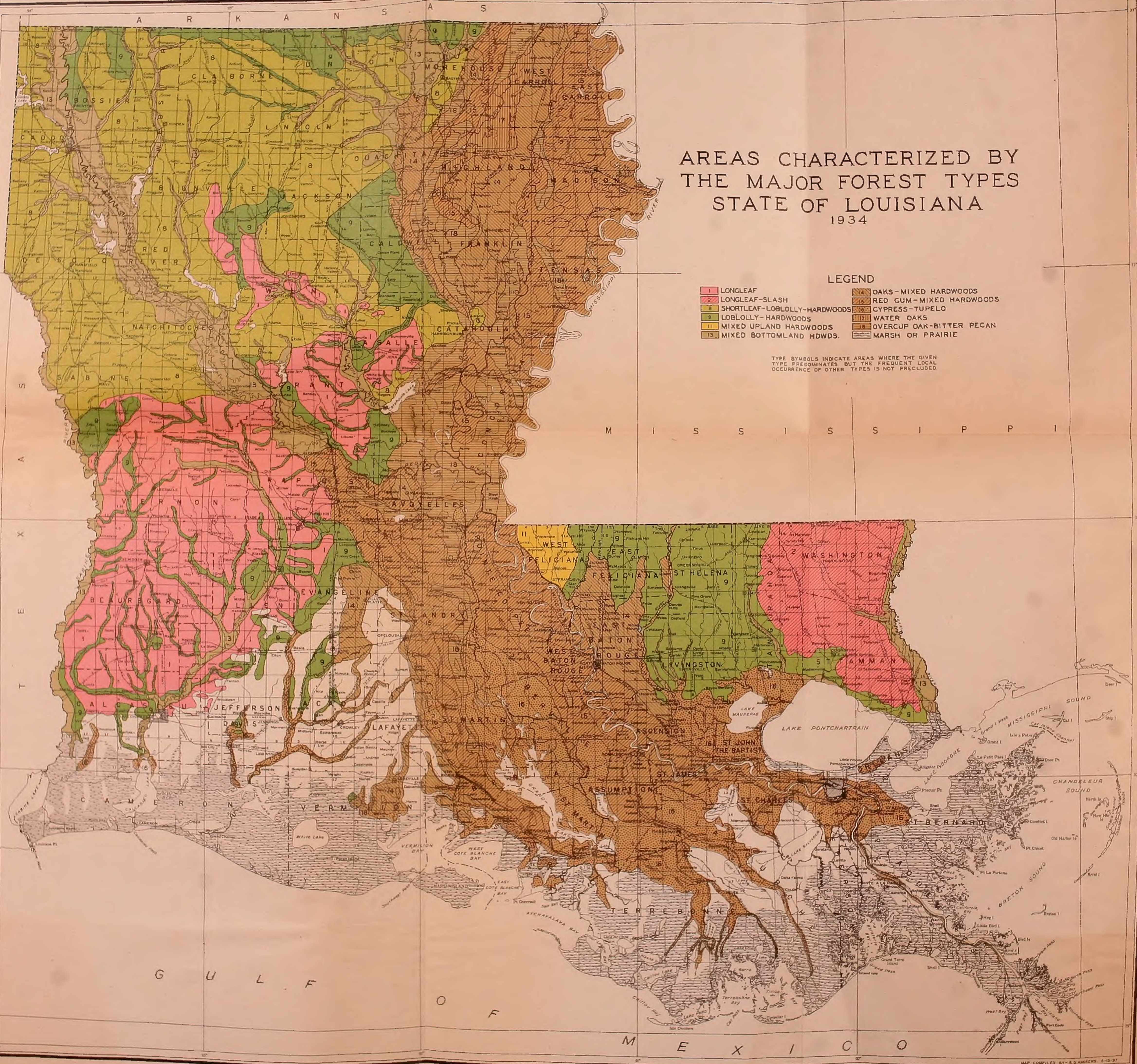




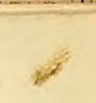


